OAK RIDGE NATIONAL LABORATORY

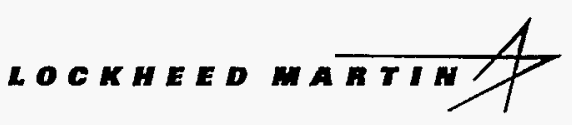

MANAGED AND OPERATED BY LOCKHEED MARTIN ENERGY RESEARCH CORPORATION FOR THE UNTED STATES DEPARTMENT OF ENERGY

\section{INTERACTIONS OF ZIRCALOY CLADDING WITH GALLIUM: FINAL REPORT}

\author{
D. F. Wilson \\ J. R. DiStefano \\ J. P. Strizak \\ J. F. King
}

E. T. Manneschmidt 
This report has been reproduced directly from the best available copy.

Available to DOE and DOE contractors from the Office of Scientific and Technical Information, P.O. Box 62, Oak Ridge, TN 37831; prices available from (423)576-8401.

Available to the public from the National Technical Information Service, U.S. Department of Commerce, 5285 Port Royal Rd., Springfield, VA 22161.

This report was prepared as an account of work sponsored by an agency of the United States Government. Neither the United States Government nor any agency thereof, nor any of their employees, makes any warranty, express or implied, or assumes any legal liability or responsibility for the accuracy, completeness, or usefulness of any information, apparatus, product, or process disclosed, or represents that its use would not infringe privately owned rights. Reference herein to any specific commercial product, process, or service by trade name, trademark, manufacturer, or otherwise, does not necessarily constitute or imply its endorsement, recommendation, or favoring by the United States Government or any agency thereof. The views and opinions of authors expressed herein do not necessarily state or reflect those of the United States Government or any agency thereof. 


\section{DISCLAIMER}

Portions of this document may be illegible in electronic image products. Images are produced from the best available original document. 
Metals and Ceramics Division

\title{
INTERACTIONS OF ZIRCALOY CLADDING WITH GALLIUM: FINAL REPORT
}

D. F. Wilson

J. R. DiStefano

J. P. Strizak

J. F. King

E. T. Manneschmidt

Date Published: September 1998

\author{
Prepared for the \\ U.S. Department of Energy \\ Office of Fissile Materials Disposition \\ GA 0102014 \\ Prepared by \\ OAK RIDGE NATIONAL LABORATORY \\ Oak Ridge, Tennessee 37831-6285 \\ managed by \\ LOCKHEED MARTIN ENERGY RESEARCH CORP. \\ for the \\ U.S. DEPARTMENT OF ENERGY \\ under contract DE-AC05-96OR22464
}


LIST OF FIGURES $\quad \ldots \ldots \ldots \ldots \ldots \ldots \ldots \ldots \ldots \ldots \ldots \ldots \ldots \ldots \ldots \ldots \ldots$

LIST OF TABLES $\ldots \ldots \ldots \ldots \ldots \ldots \ldots \ldots \ldots \ldots \ldots \ldots \ldots \ldots \ldots \ldots \ldots \ldots \ldots$

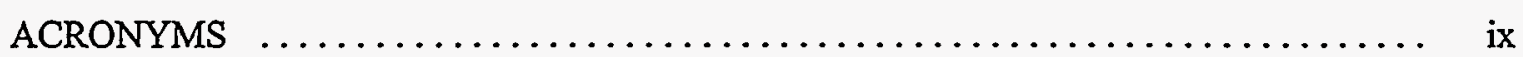

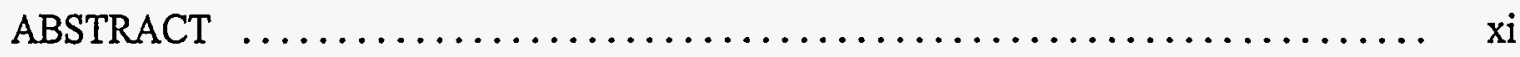

1. INTRODUCTION $\quad \ldots \ldots \ldots \ldots \ldots \ldots \ldots \ldots \ldots \ldots \ldots \ldots \ldots \ldots \ldots \ldots \ldots \ldots \ldots \ldots \ldots$

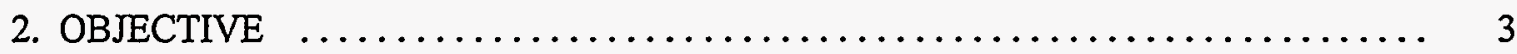

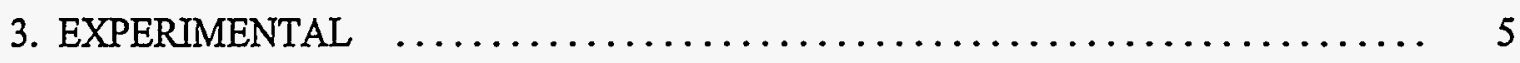

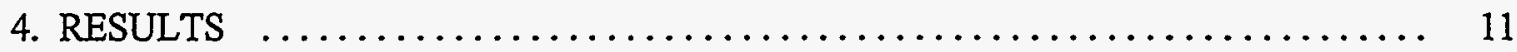

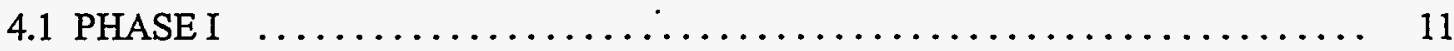

4.1 .1 Corrosion Tests $\ldots \ldots \ldots \ldots \ldots \ldots \ldots \ldots \ldots \ldots \ldots \ldots \ldots \ldots \ldots \ldots$

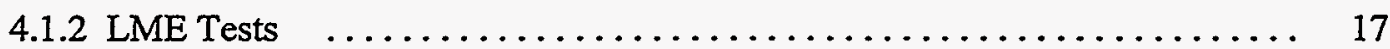

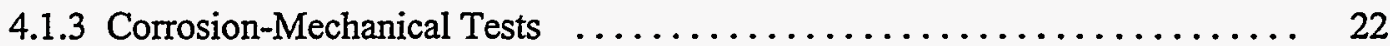

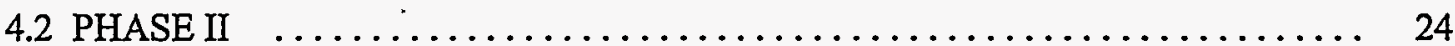

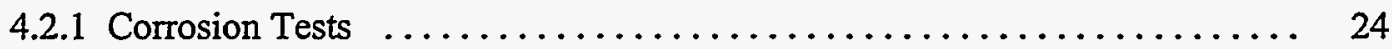

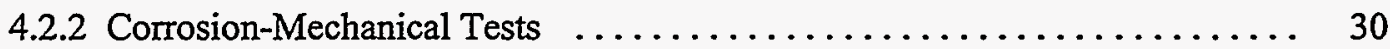

4.2.2.1 Room-Temperature Mechanical Tests $\ldots \ldots \ldots \ldots \ldots \ldots \ldots . \ldots \ldots$

4.2.2.2 High-Temperature Mechanical Tests $\ldots \ldots \ldots \ldots \ldots \ldots \ldots . \ldots . \ldots . \ldots . \ldots . \ldots$

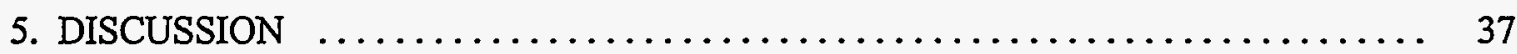

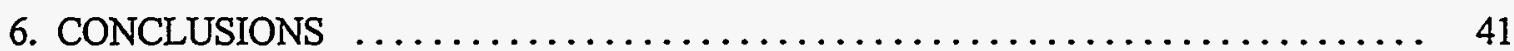

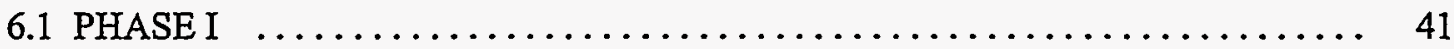

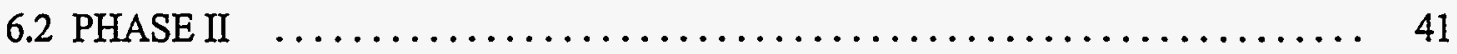

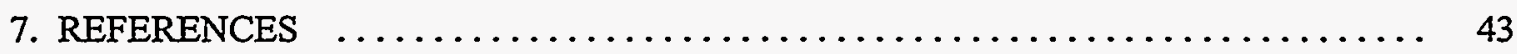

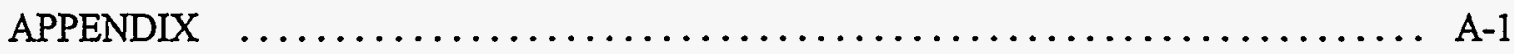




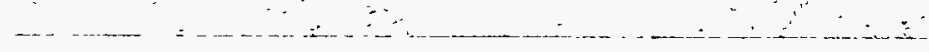

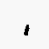

年 


\section{LIST OF FIGURES}

$\begin{array}{lll}\text { Figure } & \text { Page }\end{array}$

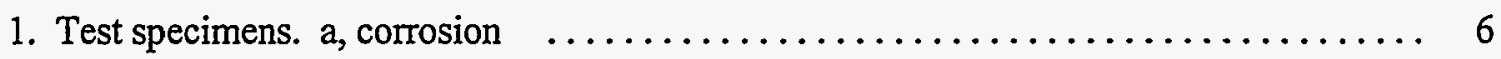

2. Gallium containment system for LME tests $\ldots \ldots \ldots \ldots \ldots \ldots \ldots \ldots \ldots \ldots$

3. Out-of-reactor tests were not prototypic of LWR fuel system relative to density and gallium concentration $\ldots \ldots \ldots \ldots \ldots \ldots \ldots \ldots \ldots \ldots \ldots$

4. Intermetallic compounds formed between gallium and zirconium

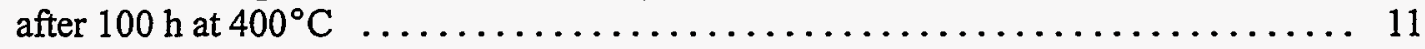

5. Brittle intermetallic compounds formed between gallium and zirconium at $400^{\circ} \mathrm{C} \quad \ldots \quad 11$

6. No attack of Zircaloy after $700 \mathrm{~h}$ at 30 or $100^{\circ} \mathrm{C} \ldots \ldots \ldots \ldots \ldots \ldots \ldots \ldots \ldots \ldots \ldots$

7. Cross sections of Zircaloy tubes after corrosion testing with excess gallium $(\mathrm{Ga})$ at $500^{\circ} \mathrm{C}$ for $200 \mathrm{~h}$ showing dimensional distortion $\ldots \ldots \ldots \ldots \ldots \ldots \ldots \ldots \ldots \ldots \ldots$

8. Corrosion testing with smaller amounts of gallium (Ga) at $500^{\circ} \mathrm{C}$ for $200 \mathrm{~h} \ldots \ldots .14$

9. Porosity in $\mathrm{Zr}_{x} \mathrm{Ga}_{y}$ formed at $500^{\circ} \mathrm{C}$ in Zircaloy material $\ldots \ldots \ldots \ldots \ldots \ldots \ldots$

10. At $300^{\circ} \mathrm{C}, \mathrm{ICF}$ decreases with decreasing time of exposure $\ldots \ldots \ldots \ldots \ldots \ldots \ldots$

11. ICF continues to decrease as the mass of gallium is decreased $\ldots \ldots \ldots \ldots \ldots \ldots$

12. LME tests showed no significant difference in strength for Zircaloy $A$

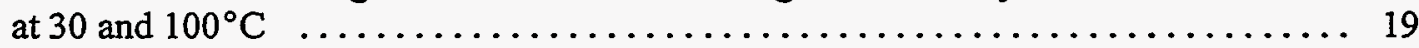

13. LME tests showed no significant difference in ductility for Zircaloy A

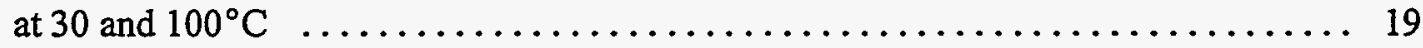

14. LME tests showed no significant difference in strength for Zircaloy $B$

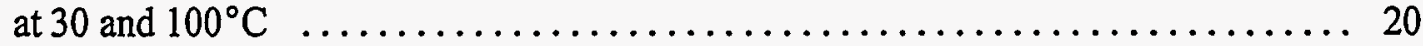

15. LME tests showed no significant difference in ductility for Zircaloy $B$

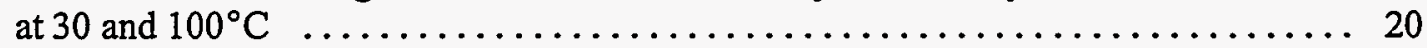

16. LME test showed no change in strength for Zircaloy $\mathrm{C}$ at 30 and $100^{\circ} \mathrm{C} \ldots \ldots \ldots 21$

17. LME tests showed no significant difference in ductility for Zircaloy $\mathrm{C}$

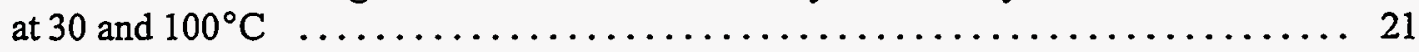

18. Ductile failure mode at 30 and $100^{\circ} \mathrm{C}$ with and without gallium $\ldots \ldots \ldots \ldots \ldots 22$

19. No change in strength observed after reaction with gallium for $30 \mathrm{~h}$ at $300^{\circ} \mathrm{C} \ldots \ldots 23$ 
20. No significant change in ductility observed after exposure to gallium

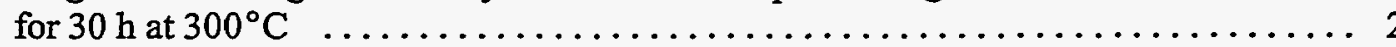

21. Ductile fracture observed after $30 \mathrm{~h}$ at $300^{\circ} \mathrm{C}$ without and with gallium $\ldots \ldots \ldots 24$

22. Zircaloy reacts with oxides at $500^{\circ} \mathrm{C}$ to form zirconium oxide $\ldots \ldots \ldots \ldots \ldots$

23. No significant reaction of Zircaloy with $\mathrm{Ga}_{2} \mathrm{O}_{3}$ after 12 weeks at $300^{\circ} \mathrm{C} \ldots \ldots \ldots 26$

24. Oxide layer present at $500^{\circ} \mathrm{C}$ for all ratios of $\mathrm{Ga}_{2} \mathrm{O}_{3}$ to cerium oxide $\ldots \ldots \ldots \ldots 27$

25. $\mathrm{Zr}_{\mathrm{x}} \mathrm{Ga}_{\mathrm{y}}$ identified below the zirconium oxide layer after exposure to

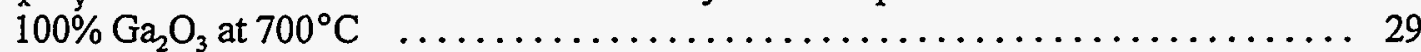

26. No significant change in room-temperature strength for Zircaloy $A$ after exposure to $\mathrm{Ga}_{2} \mathrm{O}_{3}$ in cerium oxide $\left(6\right.$ weeks at 300 and $\left.500^{\circ} \mathrm{C}\right) \quad \ldots \ldots \ldots \ldots 31$

27. Slight change in room-temperature ductility for Zircaloy $A$ after exposure to $\mathrm{Ga}_{2} \mathrm{O}_{3}$ in cerium oxide $\left(6\right.$ weeks at 300 and $\left.500^{\circ} \mathrm{C}\right) \quad \ldots \ldots \ldots \ldots \ldots \ldots$

28. No significant change in room-temperature strength for Zircaloy $B$ after exposure to $\mathrm{Ga}_{2} \mathrm{O}_{3}$ in cerium oxide $\left(6\right.$ weeks at 300 and $\left.500^{\circ} \mathrm{C}\right) \quad \ldots \ldots \ldots \ldots 32$

29. Slight change in room-temperature ductility for Zircaloy $\mathrm{B}$ after exposure to $\mathrm{Ga}_{2} \mathrm{O}_{3}$ in cerium oxide $\left(6\right.$ weeks at 300 and $\left.500^{\circ} \mathrm{C}\right) \quad \ldots \ldots \ldots \ldots \ldots 32$

30. No significant change in room-temperature strength for Zircaloy $\mathrm{C}$ after exposure to $\mathrm{Ga}_{2} \mathrm{O}_{3}$ in cerium oxide $\left(6\right.$ weeks at 300 and $\left.500^{\circ} \mathrm{C}\right) \ldots \ldots \ldots 33$

31. Slight change in room-temperature ductility for Zircaloy $\mathrm{C}$ after exposure to $\mathrm{Ga}_{2} \mathrm{O}_{3}$ in cerium oxide $\left(6\right.$ weeks at 300 and $\left.500^{\circ} \mathrm{C}\right)$

32. No significant changes in $300^{\circ} \mathrm{C}$ strength and ductility for Zircaloy $\mathrm{A}$ after exposure to $\mathrm{Ga}_{2} \mathrm{O}_{3}$ in cerium oxide $\left(6\right.$ weeks at $\left.300^{\circ} \mathrm{C}\right) \quad \ldots \ldots \ldots \ldots \ldots \ldots$

33. No significant changes in $500^{\circ} \mathrm{C}$ strength and ductility for Zircaloy $\mathrm{A}$ after exposure to $\mathrm{Ga}_{2} \mathrm{O}_{3}$ in cerium oxide $\left(6\right.$ weeks at $\left.500^{\circ} \mathrm{C}\right) \quad \ldots \ldots \ldots \ldots \ldots \ldots$

34. No significant changes in $300^{\circ} \mathrm{C}$ strength and ductility for Zircaloy $\mathrm{C}$ after exposure to $\mathrm{Ga}_{2} \mathrm{O}_{3}$ in cerium oxide $\left(6\right.$ weeks at $\left.300^{\circ} \mathrm{C}\right) \ldots \ldots \ldots \ldots \ldots \ldots$

35. No significant changes in $500^{\circ} \mathrm{C}$ strength and ductility for Zircaloy $\mathrm{C}$ after exposure to $\mathrm{Ga}_{2} \mathrm{O}_{3}$ in cerium oxide $\left(6\right.$ weeks at $\left.500^{\circ} \mathrm{C}\right) \quad \ldots \ldots \ldots \ldots \ldots \ldots$

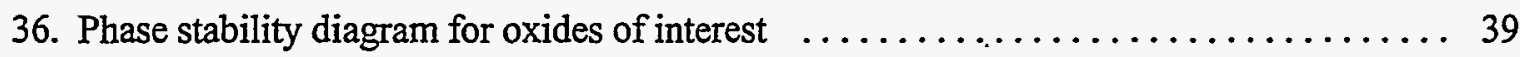




\section{LIST OF TABLES}

Table

Page

1. Composition of alloys based on zirconium $\ldots \ldots \ldots \ldots \ldots \ldots \ldots \ldots \ldots \ldots \ldots$

2. Vicker hardness ( $25 \mathrm{~g}$ load) for Zircaloys after $200 \mathrm{~h}$ at $500^{\circ} \mathrm{C}$ with gallium $\ldots \ldots \quad 15$

A.1 Supplemental compatibility tests of zirconium/Zircaloy with gallium or $\mathrm{Ga}_{2} \mathrm{O}_{3}$ in support of test design $\ldots \ldots \ldots \ldots \ldots \ldots \ldots \ldots \ldots \ldots \ldots \ldots \ldots \ldots \ldots \ldots \ldots$

A.2 Status of corrosion tests of Zircaloy with gallium metal $\quad \ldots \ldots \ldots \ldots \ldots \ldots \ldots$ A-3

A.3 Status of corrosion tests of Zircaloy with $\mathrm{Ga}_{2} \mathrm{O}_{3} \ldots \ldots \ldots \ldots \ldots \ldots \ldots \ldots \ldots \ldots$

A.4 Status of mechanical tests of Zircaloy with gallium metal $\ldots \ldots \ldots \ldots \ldots \ldots \ldots$ A-4

A.5 Status of room-temperature, corrosion-mechanical tests of Zircaloy with $\mathrm{Ga}_{2} \mathrm{O}_{3} \quad \ldots$ A-5

A.6 Status of high-temperature tensile, corrosion-mechanical tests of

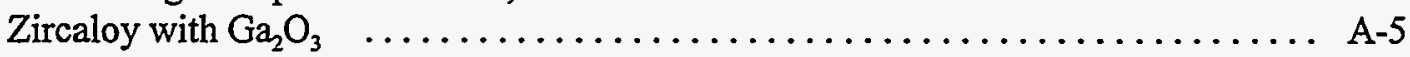




\section{ACRONYMS}

CERT constant extension rate tensile

EBW electron beam welding

IC intermetallic compound

ICF intermetallic compound formation

LANL Los Alamos National Laboratory

LBW laser beam welding

LME liquid metal embrittlement

LWR light-water reactor

MOX mixed oxide

ORNL Oak Ridge National Laboratory

WG weapons grade

wt weight 


\begin{abstract}
A program was conducted to evaluate the effect of gallium in mixed-oxide (MOX) fuel derived from weapons-grade (WG) plutonium on Zircaloy cladding performance. A four-phase experimental program was designed to evaluate the performance of prototypic Zircaloy cladding materials against (1) liquid gallium (Phase I), (2) various concentrations of $\mathrm{Ga}_{2} \mathrm{O}_{3}$ (Phase II), (3) centrally heated surrogate fuel pellets with expected levels of gallium (Phase III), and (4) centrally heated prototypic MOX fuel pellets (Phase IV). This report describes the results of tests for Phases I and II.

Three types of tests were performed: (1) corrosion, (2) liquid metal embrittlement, and (3) corrosion-mechanical. These tests were to determine corrosion mechanisms, thresholds for temperature and concentration of gallium that delineate behavioral regimes, and changes in the mechanical properties of Zircaloy.

Results have generally been favorable for the use of WG-MOX fuel. The MOX fuel cladding, Zircaloy, does react with gallium to form intermetallic compounds at $2300^{\circ} \mathrm{C}$; however, this reaction is limited by the mass of gallium and is therefore not expected to be significant with a low level (parts per million) of gallium in the MOX fuel. Although continued migration of gallium into the initially formed intermetallic compound can result in large stresses that may lead to distortion, this was shown to be extremely unlikely because of the low mass of gallium or gallium oxide present and expected clad temperatures below $400^{\circ} \mathrm{C}$. Furthermore, no evidence for grain boundary penetration by gallium or liquid metal embrittlement was observed.
\end{abstract}




\section{INTRODUCTION}

The U.S. Department of Energy has established a dual-track approach to the disposition of plutonium arising from the dismantling of nuclear weapons. Both immobilization and reactorbased mixed-oxide (MOX) fuel technologies are being evaluated. The reactor-based MOX fuel option requires assessment of the potential impact of concentrations of gallium (on the order of 1 to $10 \mathrm{ppm}$ ), not present in conventional MOX fuel, on cladding material performance. Three previous reports $^{1-3}$ identified several compatibility issues relating to the presence of gallium in MOX fuel and its possible reaction with fuel cladding.

Gallium initially present in weapons-grade (WG) plutonium is largely removed during processing to produce MOX fuel. After blending the plutonium with uranium, only 1 to $10 \mathrm{ppm}$ gallium is expected in the sintered MOX fuel. Gallium present as gallium oxide $\left(\mathrm{Ga}_{2} \mathrm{O}_{3}\right)$ could be evolved as the suboxide $\left(\mathrm{Ga}_{2} \mathrm{O}\right)$. Migration of the evolved $\mathrm{Ga}_{2} \mathrm{O}$ and diffusion of gallium in the MOX matrix along thermal gradients could lead to locally higher concentrations of $\mathrm{Ga}_{2} \mathrm{O}_{3}$. Thus, while an extremely low concentration of gallium in MOX fuel almost ensures a lack of significant interaction of gallium with Zircaloy fuel cladding, there remains a small probability that corrosion effects will not be negligible.

A number of reaction routes are possible in this clad-WG-MOX fuel system, including:

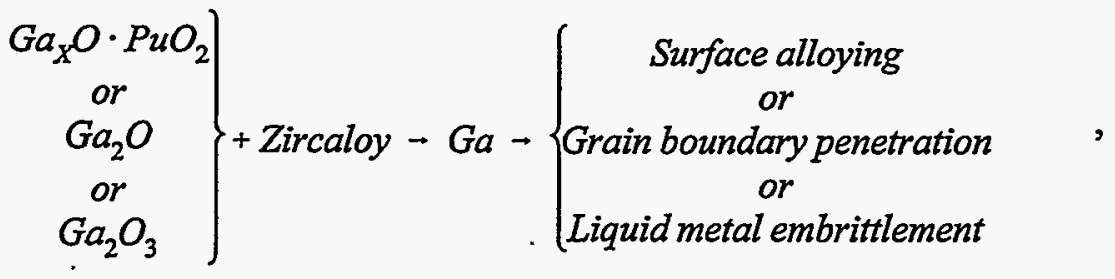

and

$$
G a_{2} \mathrm{O}_{3}+\mathrm{ZrO}_{2}-\left\{\begin{array}{c}
\text { No reaction } \\
\text { or } \\
\text { Mixed oxide }+ \text { crack }+\mathrm{Ga}
\end{array}-\left\{\begin{array}{c}
\text { Surface alloying } \\
\text { or } \\
\text { Grain boundary penetration } \\
\text { or } \\
\text { Liquid metal embrittlement }
\end{array}\right.\right.
$$


General corrosion in the form of surface alloying resulting from formation of intermetallic compounds between Zircaloy and gallium should be mass limited and, therefore, superficial because of the expected low ratio of gallium to the surface area or volume of the Zircaloy cladding. Although the expected concentration of gallium is low and there is very limited solubility of gallium in zirconium, especially at temperatures below $700^{\circ} \mathrm{C}^{4}$ grain boundary penetration and liquid metal embrittlement (LME) are forms of localized corrosion that were also considered.

One fuel system damage mechanism, pellet clad interaction, has led to some failure of the Zircaloy cladding in light-water reactors (LWRs). This has been attributed to stresses in the cladding and one or more aggressive fission products. Stress corrosion cracking by iodine ${ }^{5,6}$ and LME by cadmium ${ }^{7,8}$ have been reported, and it is known that Zircaloy can be embrittled by some low-melting metals, (e.g., mercury). ${ }^{9}$ LME is a form of environmentally induced embrittlement that can induce cracking or loss of ductility. LME requires wetting and a tensile stress, but it does not require corrosion penetration. Experimentally, it has been demonstrated that gallium can cause embrittlement of some alloys (e.g., aluminum) at low temperatures, ${ }^{10,11}$ but experiments relative to LME of zirconium by gallium have been limited and inconclusive. ${ }^{12}$

This report describes a series of tests designed to establish the effects of low levels of residual gallium in WG-MOX fuel on its compatibility with Zircaloy. In addition, to establish damage mechanisms it was important to understand types of cladding interactions and available safety margins with respect to gallium concentration. 


\section{OBJECTIVE}

The overall objective of this task is to demonstrate the effects of small concentrations of gallium in MOX fuel on the performance of the fuel system in an LWR. Although possible mechanisms for gallium interaction with Zircaloy have been identified, ${ }^{1-3}$ no significant data exist that demonstrate whether such reactions actually occur under LWR conditions and whether these reactions have any significant effects on cladding performance. In the planned program, a graded, experimental approach was designed to determine whether low levels of gallium would result in damage to the fuel clad. This approach was divided into four phases. In Phase I, laboratory tests were conducted on three prototypic Zircaloy cladding materials in liquid gallium. Three types of tests were used: (1) corrosion, (2) LME, and (3) corrosion-mechanical. Corrosion tests consisted of time-temperature exposures of Zircaloy to liquid gallium. LME tests consisted of slow strain rate, constant extension rate tensile (CERT) tests in gallium metal at low temperature $\left(30\right.$ and $\left.100^{\circ} \mathrm{C}\right)$. Corrosion-mechanical tests consisted of first exposing the Zircaloy to gallium metal and then conducting a tensile test to evaluate corrosion product effects. Although these Phase I tests conditions (much higher relative amount of gallium compared with that in a fuel rodlet) are not representative of WG-MOX, they provide limiting boundary conditions for mechanistic studies. The test matrices for Phase I are shown in the Appendix.

In Phase II, two of the previously mentioned types of tests, corrosion and corrosionmechanical, were conducted with the three cladding materials in contact with $\mathrm{Ga}_{2} \mathrm{O}_{3}$. In each type of test, four concentrations of $\mathrm{Ga}_{2} \mathrm{O}_{3}$ in $\mathrm{Ce}_{2} \mathrm{O}_{3}$ (surrogate for plutonium dioxide) were evaluated: $100,1,0.2$, and 0.1 weight (wt) \%. Although these levels of $\mathrm{Ga}_{2} \mathrm{O}_{3}$ are all considerably higher than those possible in a sintered MOX pellet, ${ }^{13}$ they can be used to determine the types of reactions that could occur, and, like Phase I tests, they represent a conservative evaluation of $\mathrm{Ga}_{2} \mathrm{O}_{3}$ effects in this screening test phase. The test matrices for Phase II are shown in the Appendix.

Phase III tests were designed to expose cladding material to centrally heated surrogate fuel pellets manufactured by Los Alamos National Laboratory (LANL). These sintered, annular pellets, $\mathrm{U} / \mathrm{Ce} / \mathrm{Ga} / \mathrm{O}$, contain less than $0.001 \mathrm{wt} \%$ gallium and have a density of more than $94 \%$. The Texas A\&M University Nuclear Science Center designed a nonpressurized test system for the centrally heated pellet tests. To simulate the thermal gradients across operating reactor pellets and to test for thermally driven gallium diffusion, a small diameter $(\sim 0.46-\mathrm{cm}$ outside diameter) electric heater is inserted into the center of the surrogate pellets. The heater is designed to operate at a temperature of about $1000^{\circ} \mathrm{C}$ with a linear power of $15.7 \mathrm{~kW} / \mathrm{m}$. The experiment is configured to produce a nominal cladding-pellet interface temperature of $400^{\circ} \mathrm{C}$. Six $10.2-\mathrm{cm}$ 
"rodlets" can be centrally heated and individually withdrawn for evaluation. Phase III will not be completed as part of this program. However, the heat transfer modeling results will be reported elsewhere.

Work related to the planned Phase IV was not implemented. If conducted, Phase IV tests would have been similar to Phase III tests, except that prototypic MOX fuel pellets would have been used. 


\section{EXPERIMENTAL}

Prototypical LWR cladding materials evaluated included Zircaloy-2, Zircaloy-4, and Zirlo. Compositional ranges for these alloys are presented in Table 1.

Table 1. Composition of alloys based on zirconium (weight percent except where noted)

\begin{tabular}{lcccccc}
\hline Alloy & $\mathrm{Sn}$ & $\mathrm{Fe}$ & $\mathrm{Cr}$ & $\mathrm{Ni}$ & $\mathrm{Nb}$ & $\begin{array}{c}0 \\
(\mathrm{ppm})\end{array}$ \\
\hline Zircaloy-2 $^{*}$ & $1.2-1.7$ & $0.07-0.2$ & $0.05-0.15$ & $0.03-0.08$ & & $1000-1400$ \\
Zircaloy-4* $^{*}$ & $1.2-1.7$ & $0.18-0.24$ & $0.07-0.13$ & & & $1000-1400$ \\
Zirlo $^{\dagger}$ & $0.96-0.98$ & $0.094-0.105$ & $79-83 \mathrm{ppm}$ & & $1.02-1.14$ & $900-1200$ \\
\hline
\end{tabular}

"R. W. Cahn, P. Haasen, and E. J. Kramer, "Materials, Science, and Technology," Vol. 10b, p. 11, Nuclear Materials, Part 2, 1994.

${ }^{\dagger}$ G. P. Sabol et al., "In-Reactor Corrosion Performance of Zirlo and Zircaloy-4," Zirconium in the Nuclear Industry: Tenth International Symposium, pp. 724-744 in ASTM STP 1245, ed. A. M. Garde and E. R. Bradley, American Society for Testing and Materials, Philadelphia, 1994.

Zircaloy tubing was machined into two different lengths, one for corrosion tests and another for LME or corrosion-mechanical tests, as shown in Fig. 1. End caps with and without threaded ends were machined from Zircaloy bar stock for tensile and corrosion tests, respectively. First, one end cap was welded to the specimen tube, a predetermined quantity of reactant was then added, and the other end cap was welded in place. Because of the reactive nature of the zirconium alloys with oxygen and nitrogen, all welding was performed in either high vacuum using the electron beam welding (EBW) process or in a high-purity, helium-purged welding chamber using the laser beam welding (LBW) process. The completed test specimens for corrosion tests were encapsulated in an evacuated quartz capsule for atmospheric protection during high-temperature exposure (Fig. 1). For mechanical testing above $100^{\circ} \mathrm{C}$, a vacuum chamber with induction heating was used to preclude reaction of the zirconium alloys with ambient oxygen and nitrogen during testing. For the LME tests, the system shown in Fig. 2 was used to contain the liquid gallium after fracture of the specimen. The specimen was heated using copper coils containing glycol from a recirculating constant temperature bath. 


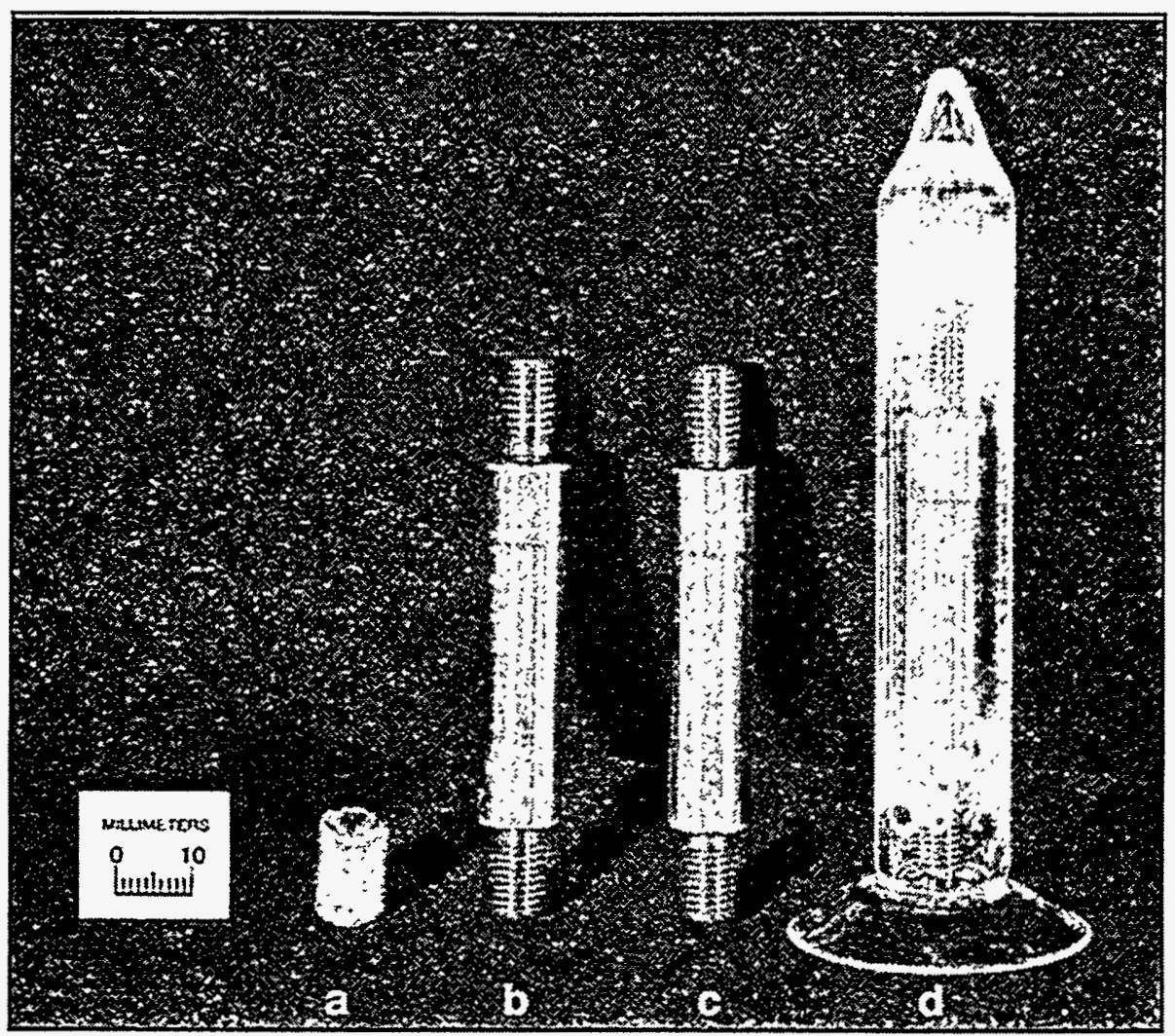

Fig. 1. Test specimens. a, corrosion; b, LME; c, corrosion-mechanical; $\mathrm{d}$, encapsulated in quartz. 


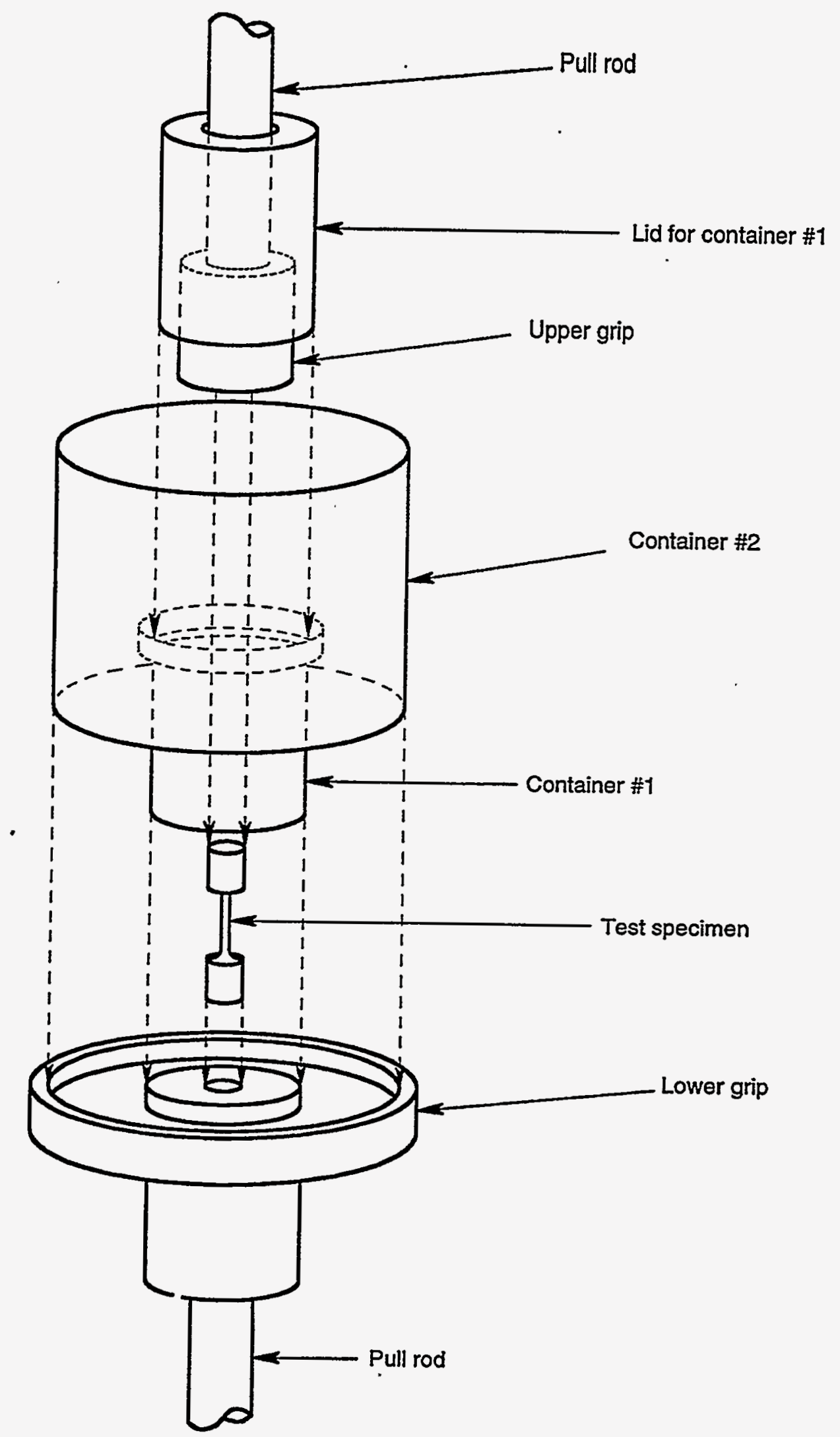

Fig. 2. Gallium containment system for LME tests. 
In addition to preliminary tests that were performed at 400 and $600^{\circ} \mathrm{C}$, corrosion tests in liquid gallium were conducted at three temperatures $\left(30,100\right.$, and $\left.500^{\circ} \mathrm{C}\right)$ for two exposure times (200 and $700 \mathrm{~h}$ ). $\mathrm{Ga}_{2} \mathrm{O}_{3}$ or surrogate gallium-containing oxide tests were also conducted at three temperatures $\left(300,500\right.$, and $\left.700^{\circ} \mathrm{C}\right)$ for two exposure times ( 6 and 12 weeks). LME tests were conducted in liquid gallium at 30 and $100^{\circ} \mathrm{C}$. Corrosion-mechanical tests in liquid gallium were conducted by first exposing the Zircaloy for $30 \mathrm{~h}$ at $300^{\circ} \mathrm{C}$ and then conducting a roomtemperature tensile test. With $\mathrm{Ga}_{2} \mathrm{O}_{3}$, tensile tests were conducted at room temperature and at the corrosion test temperature after exposure for 6 weeks at 300 and $500^{\circ} \mathrm{C}$. The temperature range brackets the normal, operating clad temperature of $374^{\circ} \mathrm{C}$.

These tests were intended to characterize the types of gallium-cladding interaction that occur and determine how these interactions might affect cladding properties. Thus, the amount and distribution of gallium was significantly different than would occur in a fuel pin as indicated in Fig. 3. The MOX fuel consists of a high density, sintered pellet with a very small quantity (ppm level) of gallium. In contrast, Phase I and Phase II tests contain either $100 \%$ Ga (liquid or oxide) or low density powder mixtures of $\mathrm{Ga}_{2} \mathrm{O}_{3}$ with $\mathrm{Ce}_{2} \mathrm{O}_{3}$.

Posttest analyses of cross sections of the clad tubes included metallography, fractography, and chemical microprobe. In the case of the corrosion tests, evidence of wall thinning, grain boundary penetration, transgranular attack, and intermetallic compound formation (ICF), when present, were documented. For the mechanical tests (LME or corrosionmechanical), the tensile strength and ductility of specimens tested in the presence of gallium or after exposure to gallium were compared with those tested in the absence of gallium. 


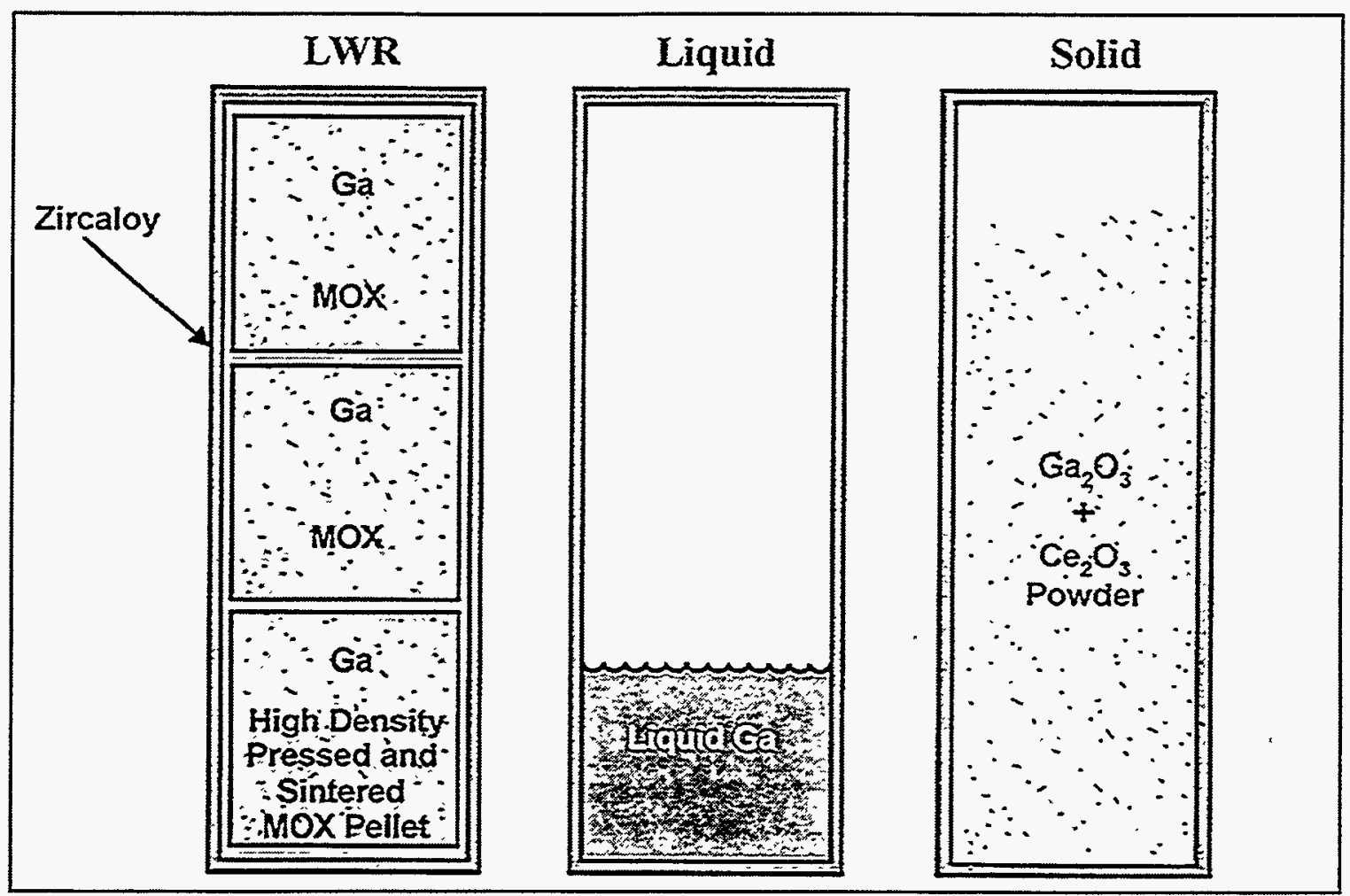

Fig. 3. Out-of-reactor tests were not prototypic of LWR fuel system relative to density and gallium concentration. 


\section{RESULTS}

\subsection{PHASE I}

\subsubsection{Corrosion Tests}

In preliminary corrosion tests of zirconium by liquid gallium at $400^{\circ} \mathrm{C}$ and Zircaloy-2 (nonvendor-supplied) at $600^{\circ} \mathrm{C}$, ICF was found as would be predicted from the galliumzirconium phase diagram. As shown in Fig. 4, electron beam microprobe analysis identified several intermetallic compounds. No unreacted gallium remained in these tests. These intermetallic compounds are hard and brittle as shown in Fig. 5.

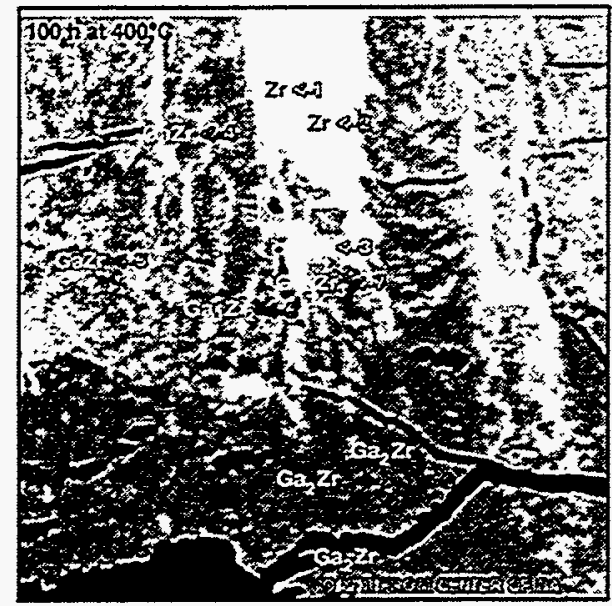

Fig. 4. Intermetallic compounds formed between gallium and zirconium after $100 \mathrm{~h}$ at $400^{\circ} \mathrm{C}$.

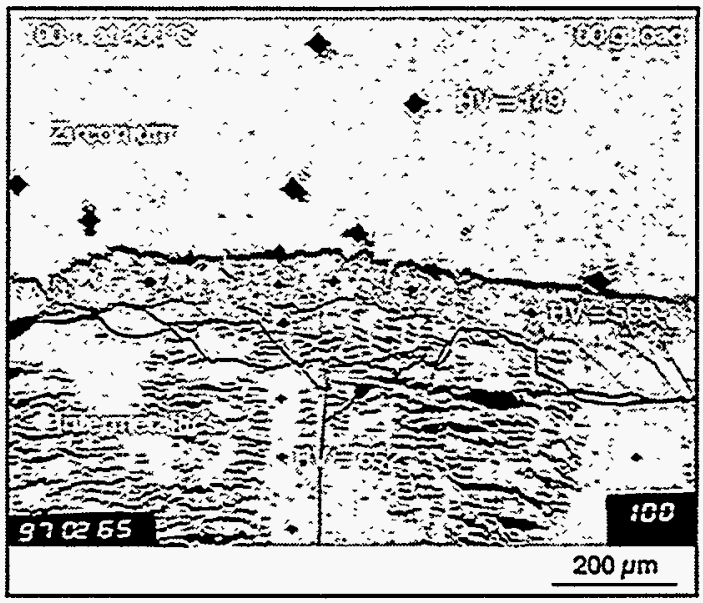

Fig. 5. Brittle intermetallic compounds formed between gallium and zirconium at $400^{\circ} \mathrm{C}$.

After exposure to liquid gallium for $700 \mathrm{~h}$ at 30 and $100^{\circ} \mathrm{C}$, none of the Zircaloy materials showed evidence of significant interaction as indicated by the typical results shown in Fig. 6. At $500^{\circ} \mathrm{C}$, all of the gallium reacted with Zircaloy to form intermetallic compounds (ICs) of the type $\mathrm{Zr}_{x} \mathrm{Ga}_{y}$ after 200 or $700 \mathrm{~h}$. Dimensional distortion of some Zircaloy capsules was observed as a result of exposure at $500^{\circ} \mathrm{C}$ (Fig. 7). 


\section{$30^{\circ} \mathrm{C} / 700 \mathrm{~h}$}
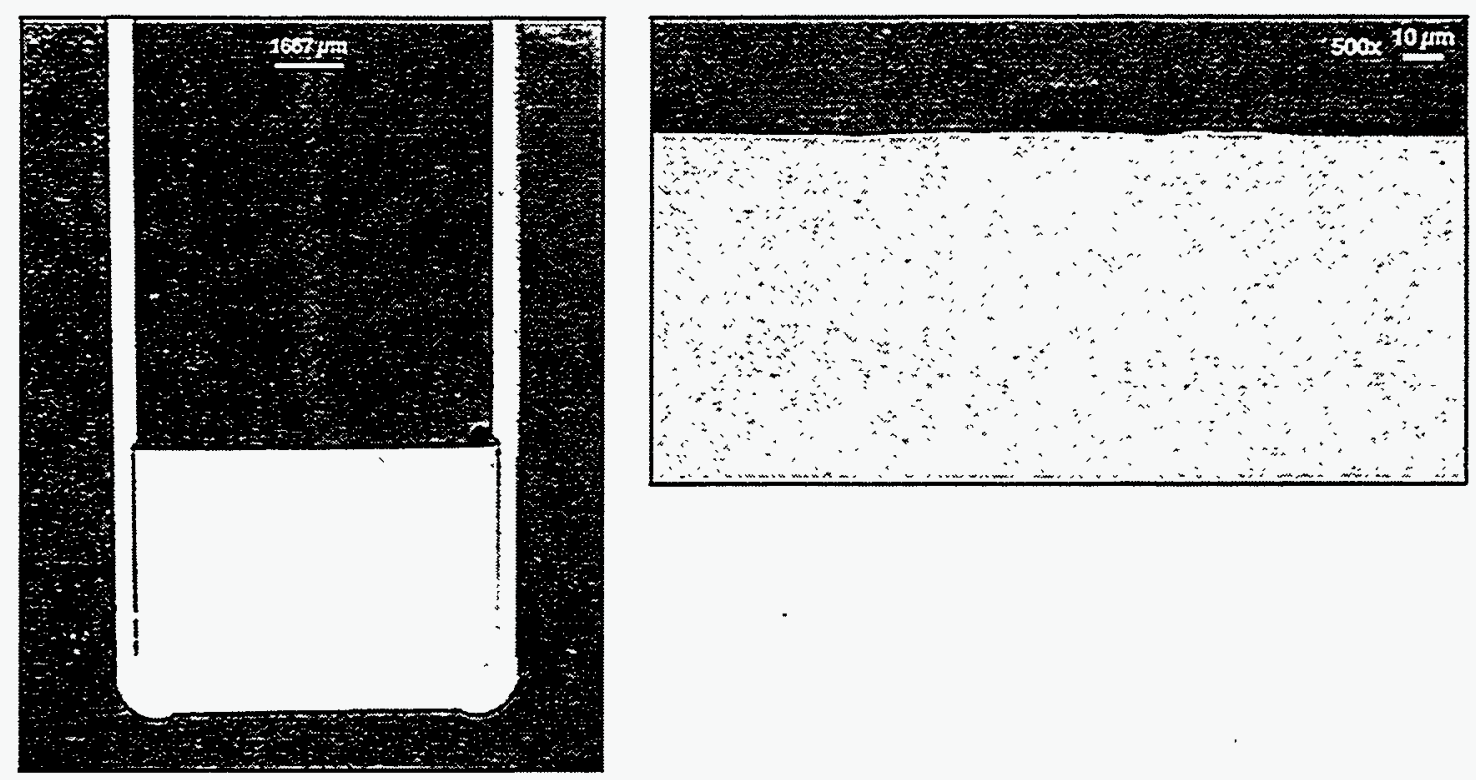

$100^{\circ} \mathrm{C} / 700 \mathrm{~h}$
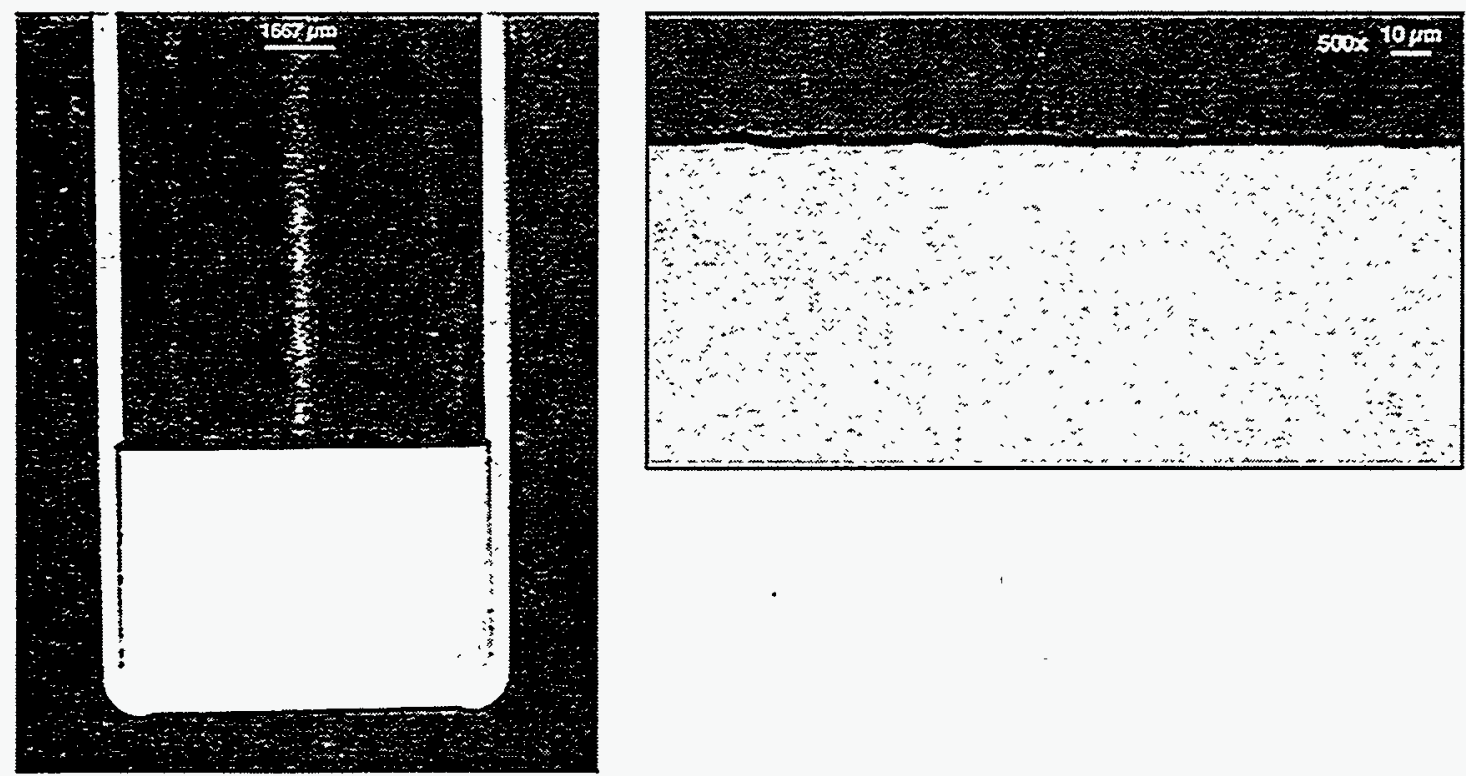

Fig. 6. No attack of Zircaloy after $700 \mathrm{~h}$ at 30 or $100^{\circ} \mathrm{C}$.

Subsequent investigation revealed that the amount of distortion was not related to the end-cap geometry or the internal gas pressure [as determined by whether EBW or LBW (Fig. 7) was used]. However, distortion was a function of the amount of gallium initially in the capsule 


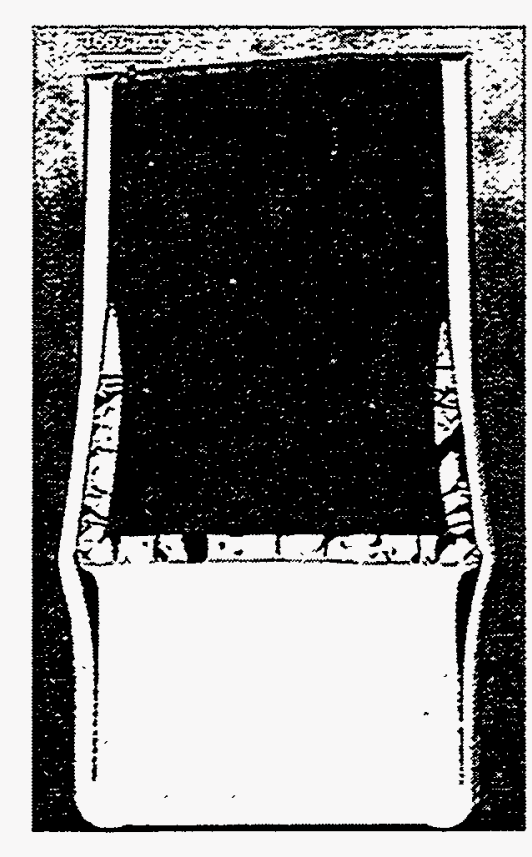

a

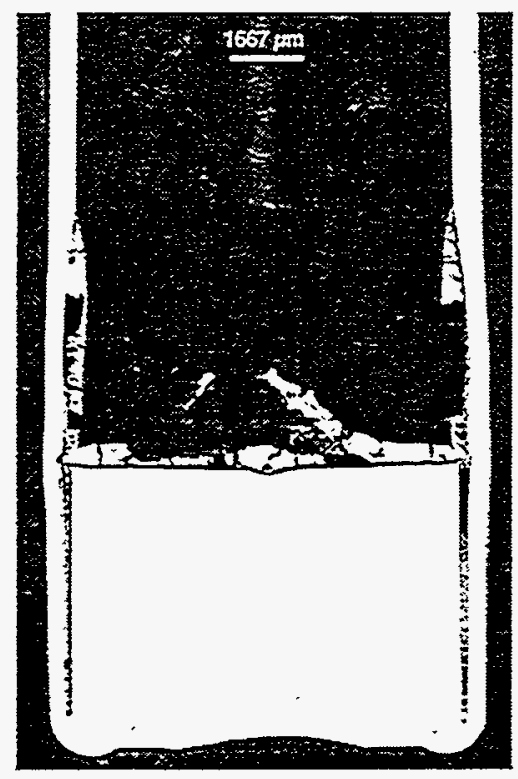

b

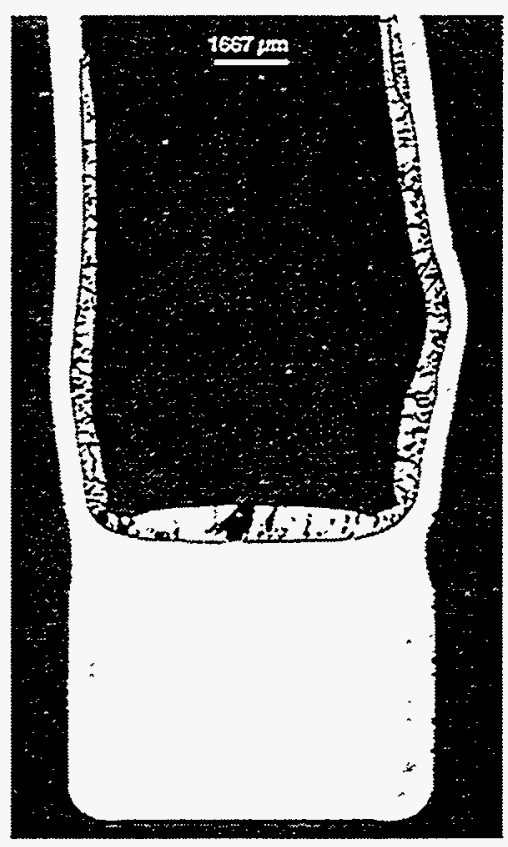

c

Fig. 7. Cross sections of Zircaloy tubes after corrosion testing with excess gallium (Ga) at $500^{\circ} \mathrm{C}$ for $200 \mathrm{~h}$ showing dimensional distortion. Distortion from formation of $\mathrm{Zr}_{\mathrm{x}} \mathrm{Ga}_{\mathrm{y}}$ is independent of welding technique. $a=L B W, 0.5 \mathrm{~g} \mathrm{Ga} ; \mathrm{b}=\mathrm{EBW}, 0.5 \mathrm{~g} \mathrm{Ga} ; \mathrm{c}=$ no crevice, $0.6 \mathrm{~g}$ $\mathrm{Ga}$. 
even though there was considerable empty space remaining within the capsule at the end of the test (Fig. 8). One of the Zircaloy materials showed little or no distortion even at the highest amounts of gallium, despite the fact that $\mathrm{Zr}_{x} \mathrm{Ga}_{y}$ type of IC formed. Comparisons of the corrosion products at high magnifications showed some differences in the appearance of the ICs. Where no distortion occurred, the corrosion product was more porous than where distortion did occur (Fig. 9).

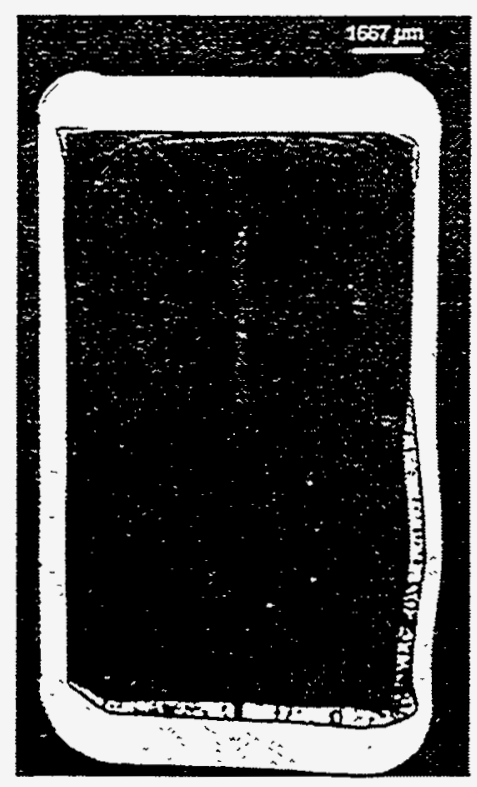

a

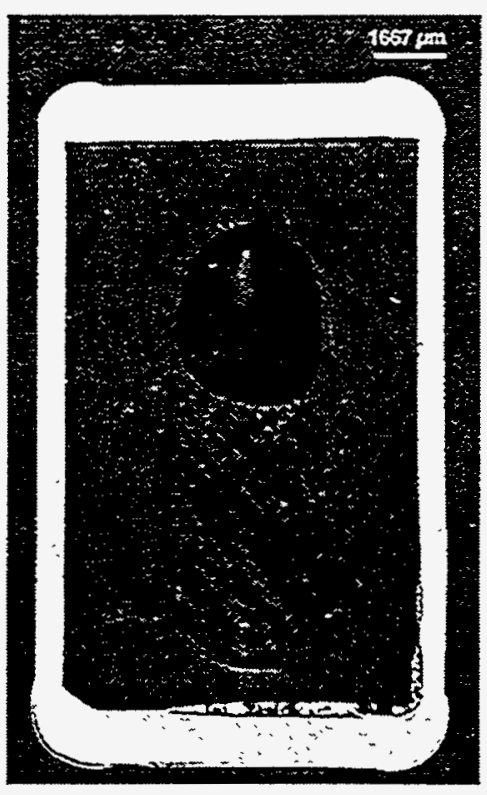

$\mathrm{b}$

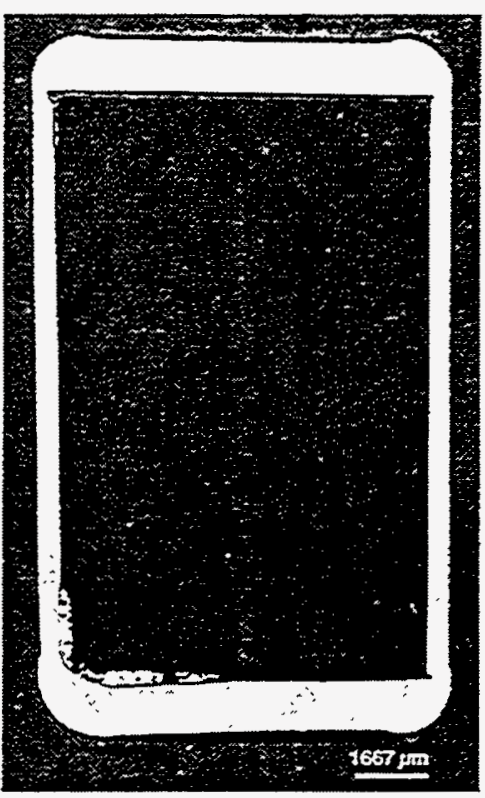

c

Fig. 8. Corrosion testing with smaller amounts of gallium (Ga) at $500^{\circ} \mathrm{C}$ for $200 \mathrm{~h}$. $\mathrm{a}=0.2 \mathrm{~g} \mathrm{Ga}$, shows a small amount of dimensional distortion; $\mathrm{b}=0.09 \mathrm{~g} \mathrm{Ga}$, shows minor dimensional distortion; $c=0.05 \mathrm{~g} \mathrm{Ga}$, shows no dimensional distortion.

The results of hardness measurements across the reaction zones are shown in Table 2.

The reaction zones have hardness numbers significantly higher than those for the base metal. In all cases, as would be expected, the hardness numbers for the porous layers were less than those for the layers between the porous layer and the base metal. Because of the large standard deviations associated with these numbers, no inferences can be made with respect to susceptibility to distortion.

Further testing at temperatures below $500^{\circ} \mathrm{C}$ showed that, in the susceptible materials, dimensional distortion also occurred at 400 and $350^{\circ} \mathrm{C}$ but was not found after $200 \mathrm{~h}$ at $300^{\circ} \mathrm{C}$. After $200 \mathrm{~h}$ at $300^{\circ} \mathrm{C}$, there was a large amount of unreacted gallium in the capsule at the end of the test. The rate of reaction is very slow at $\leq 300^{\circ} \mathrm{C}$, evidenced by the decreasing amount of corrosion product formed at $\leq 200 \mathrm{~h}$ (Fig. 10). 

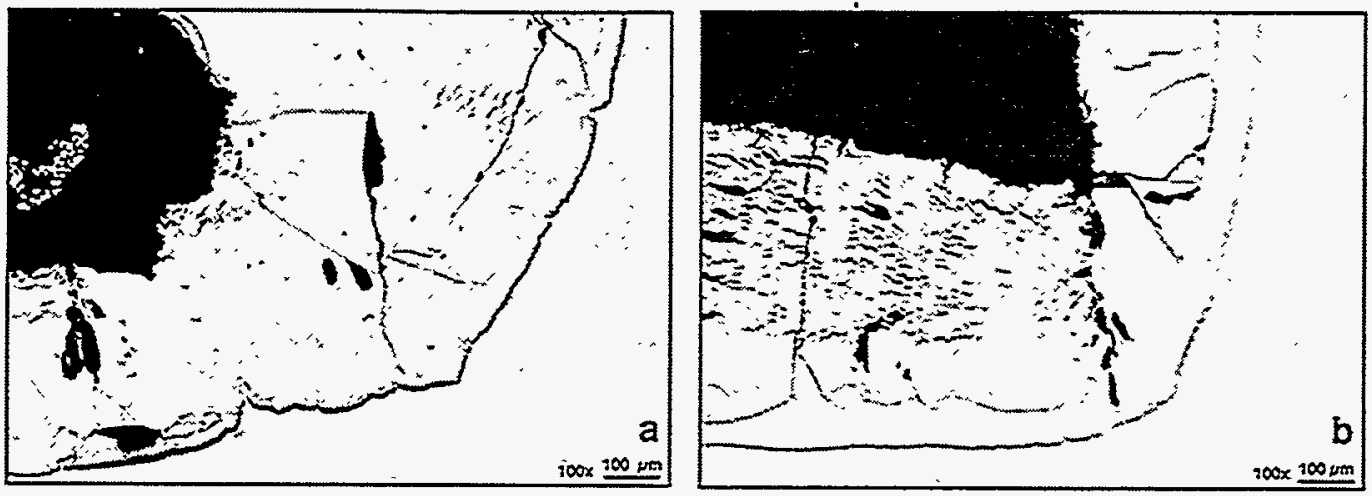

Fig. 9. Porosity in $\mathrm{Zr}_{x} \mathrm{Ga}_{y}$ formed at $500^{\circ} \mathrm{C}$ in Zircaloy material. a, material that distorted; $b$, material that did not distort.

Table 2. Vicker hardness ( $25 \mathrm{~g}$ load) for Zircaloys after $200 \mathrm{~h}$ at $500^{\circ} \mathrm{C}$ with gallium

\begin{tabular}{lcccc}
\hline Material & Porous layer & $\begin{array}{c}\text { Layer adjacent } \\
\text { to porous layer }\end{array}$ & $\begin{array}{c}\text { Layer } \\
\text { Difference }\end{array}$ & Base Metal \\
\hline Zircaloy A & $397 \pm 49^{a}$ & $776 \pm 58$ & 379 & $190 \pm 5$ \\
Zircaloy B & $691 \pm 236$ & $1136 \pm 25$ & 445 & $167 \pm 5$ \\
Zircaloy C & $406 \pm 62$ & $887 \pm 119$ & 481 & $188 \pm 7$ \\
\hline
\end{tabular}

${ }^{a}$ Standard deviation. 


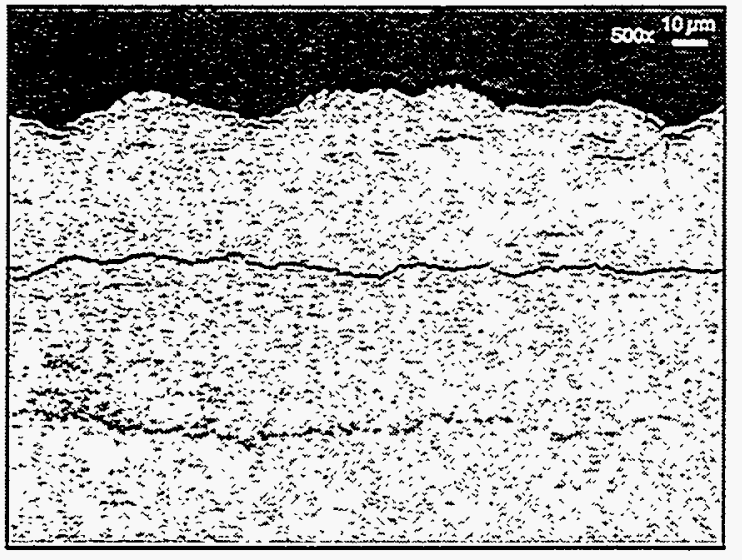

$200 \mathrm{~h}$

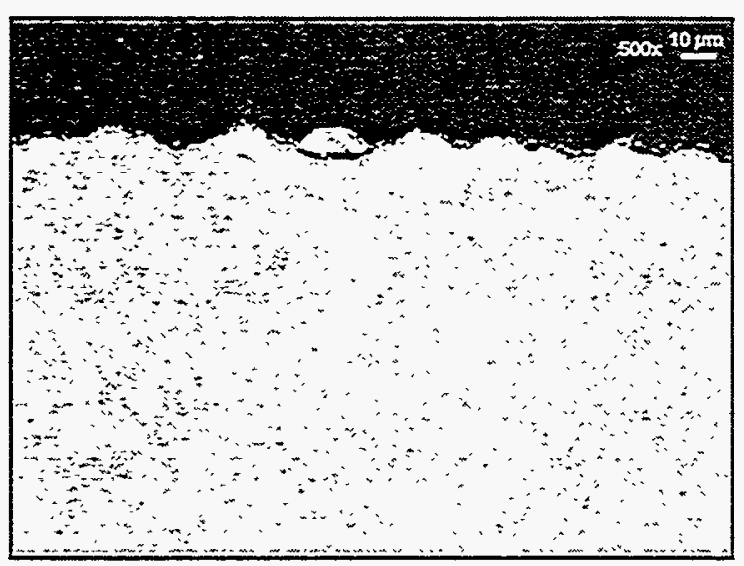

$50 \mathrm{~h}$

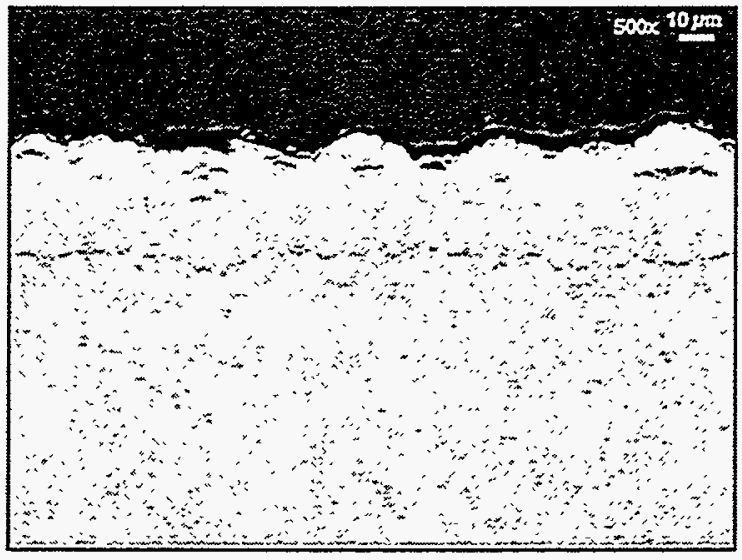

$100 \mathrm{~h}$

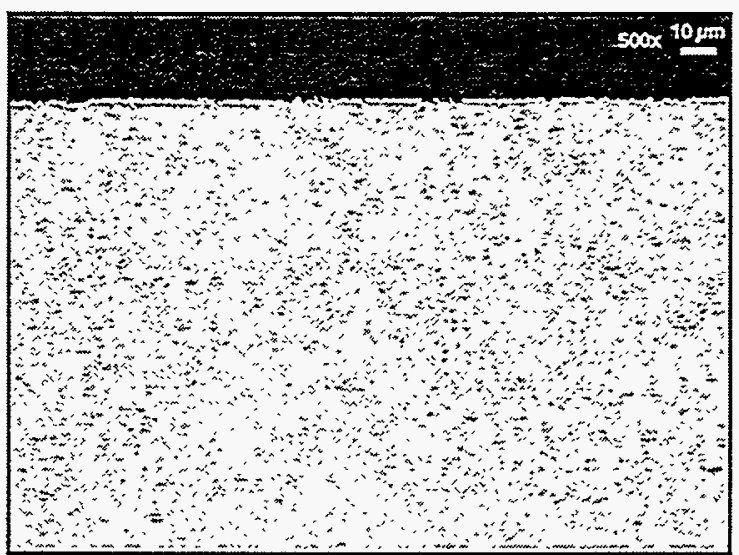

$30 \mathrm{~h}$

Fig. 10. At $300^{\circ} \mathrm{C}, \mathrm{ICF}$ decreases with decreasing time of exposure. 
As indicated in Fig. 8, dimensional distortion at $500^{\circ} \mathrm{C}$ was eliminated when smaller amounts of gallium were used in the capsule. In subsequent tests at $500^{\circ} \mathrm{C}$ with even smaller quantities of gallium $(0.025$ to $0.00038 \mathrm{~g})$,

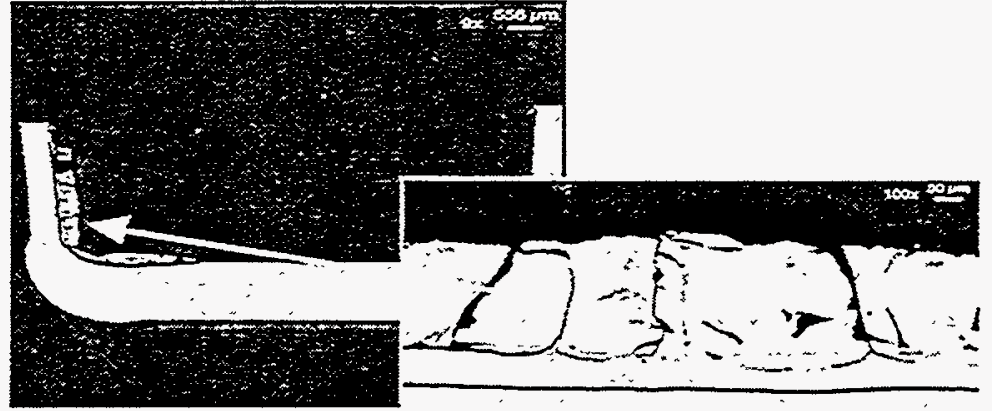

$0.025 \mathrm{~g} \mathrm{Ga}$

ICF was localized to specific regions where gallium chemically wet the capsule wall but the depth of interaction was quite shallow (Fig. 11).

In subsequent tensile tests, it was noted that the Zircaloy material that resisted distortion was somewhat weaker than the other two materials, and its tensile properties were unchanged after exposure at 300 or $500^{\circ} \mathrm{C}$. The two stronger materials became weaker and more ductile after heat treatment at $500^{\circ} \mathrm{C}$, suggesting that this heat treatment might be used to reduce susceptibility to

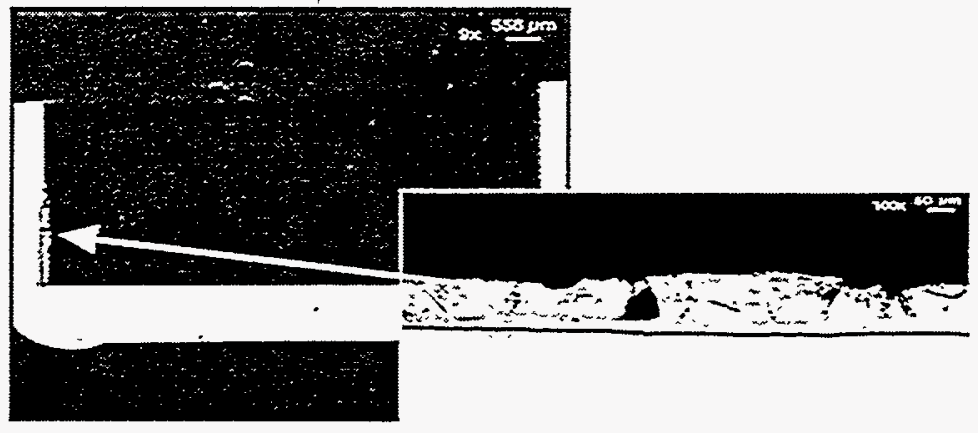

$0.0025 \mathrm{~g} \mathrm{Ga}$

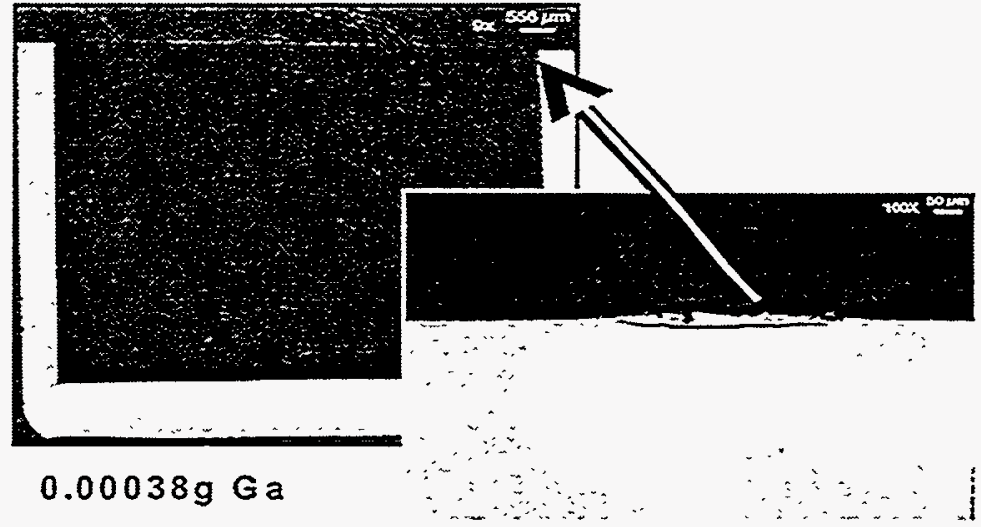

Fig. 11. ICF continues to decrease as the mass of gallium is decreased.

distortion. However, exposure to gallium at $500^{\circ} \mathrm{C}$ continued to produce distortion in these materials even after a preexposure heat treatment for $200 \mathrm{~h}$ at $500^{\circ} \mathrm{C}$.

\subsubsection{LME Tests}

CERT tests $\left(3.33 \times 10^{-6} / \mathrm{s}\right)$ were conducted in gallium at 30 and $100^{\circ} \mathrm{C}$, and the results (average of three specimens per condition) are shown in Figs. 12 to 17. No differences in the tensile properties were found between the tests in gallium compared with those at the same 
temperature without gallium. Although there was a small decrease in strength from 30 to $100^{\circ} \mathrm{C}$, this same change occurred without gallium as well. Furthermore, the specimens all failed in a ductile manner, as shown in Fig. 18. 


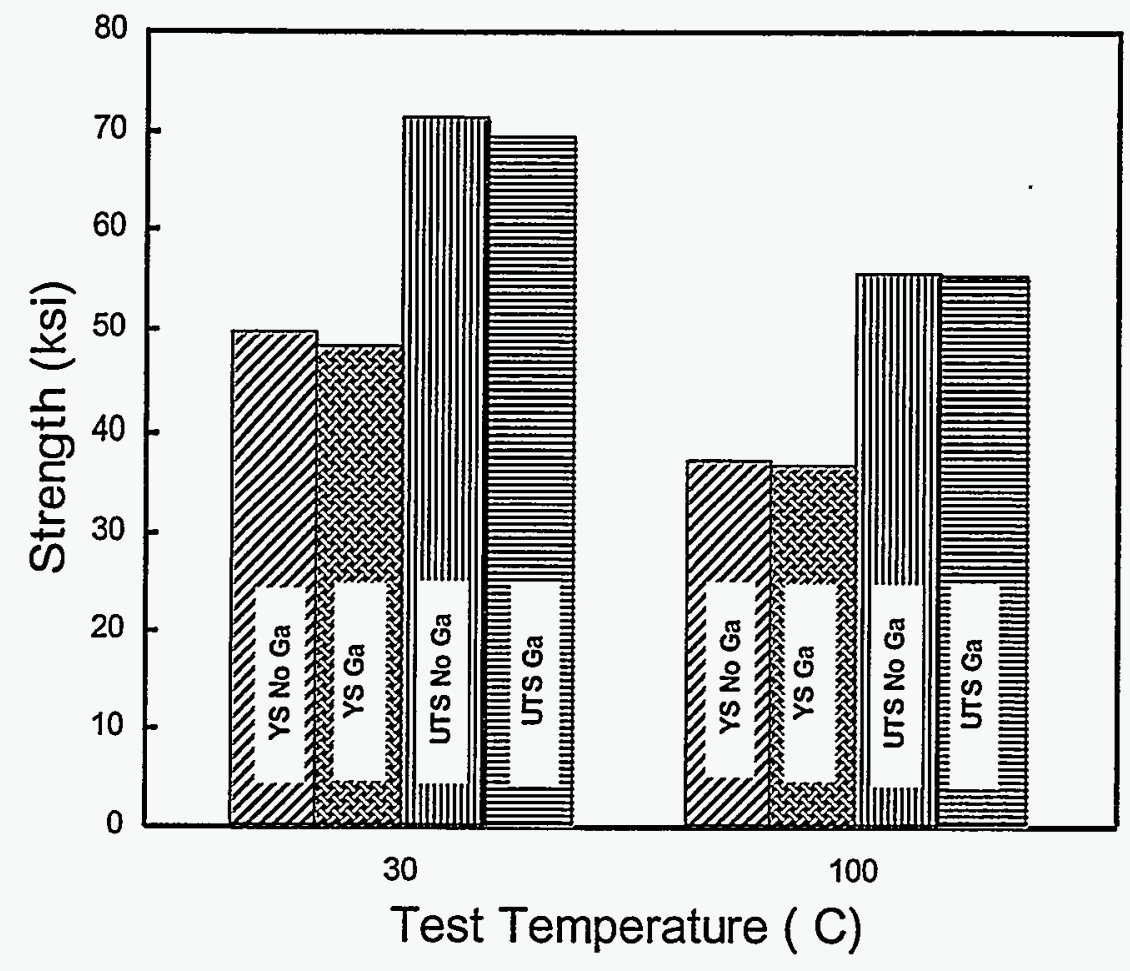

Fig. 12. LME tests showed no significant difference in strength for Zircaloy $A$ at 30 and $100^{\circ} \mathrm{C}$. YS, yield strength; UTS, ultimate tensile strength.

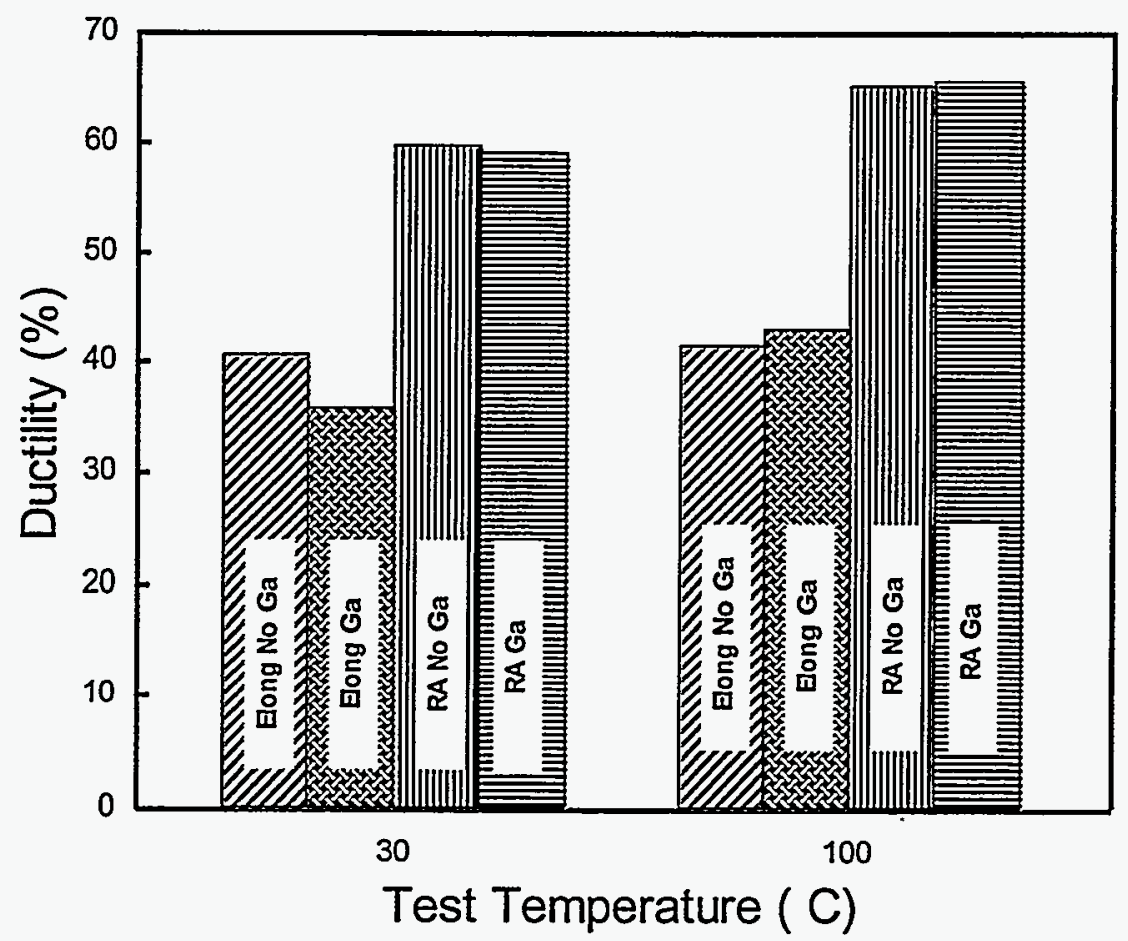

Fig. 13 . LME tests showed no significant difference in ductility for Zircaloy $A$ at 30 and $100^{\circ} \mathrm{C}$. Elong, elongation; RA, reduction in cross sectional area. 


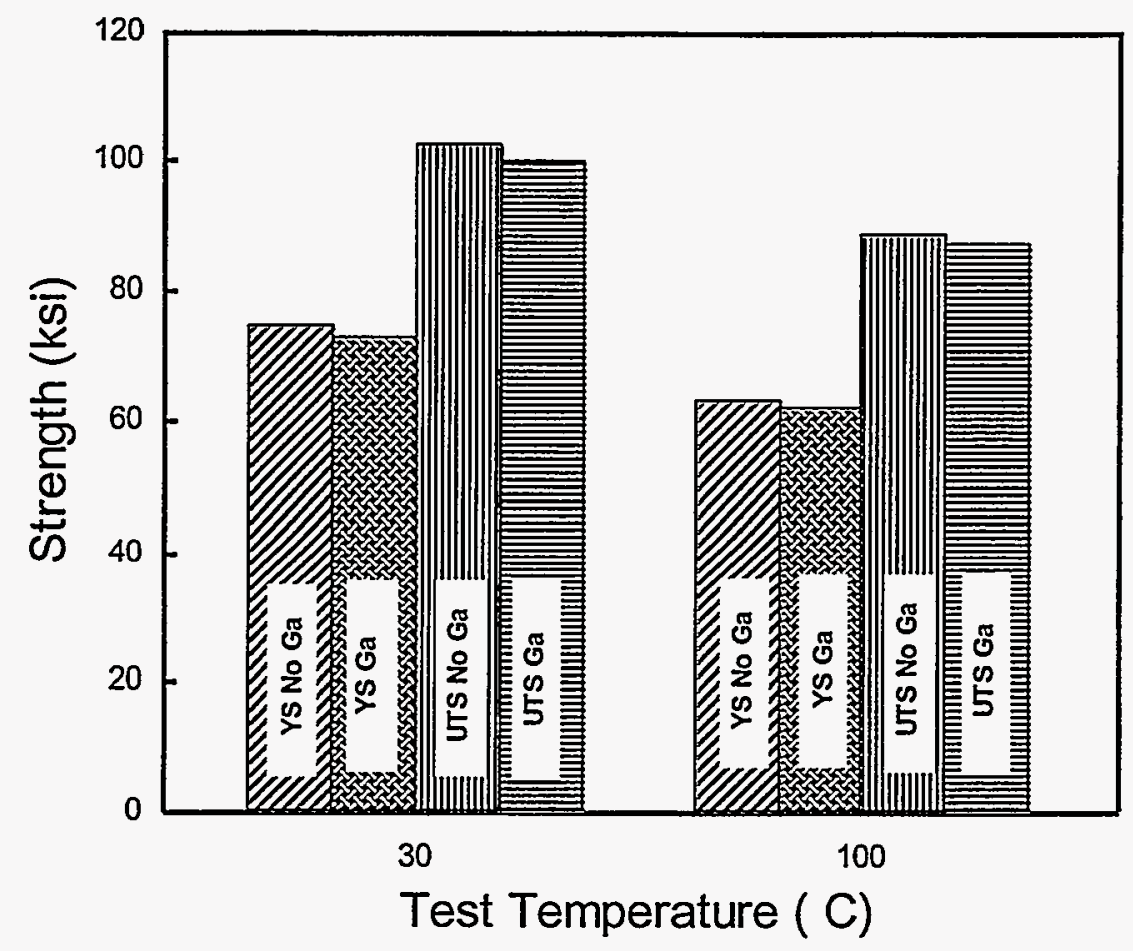

Fig. 14. LME tests showed no significant difference in strength for Zircaloy B at 30 and $100^{\circ} \mathrm{C}$. YS, yield strength; UTS, ultimate tensile strength.

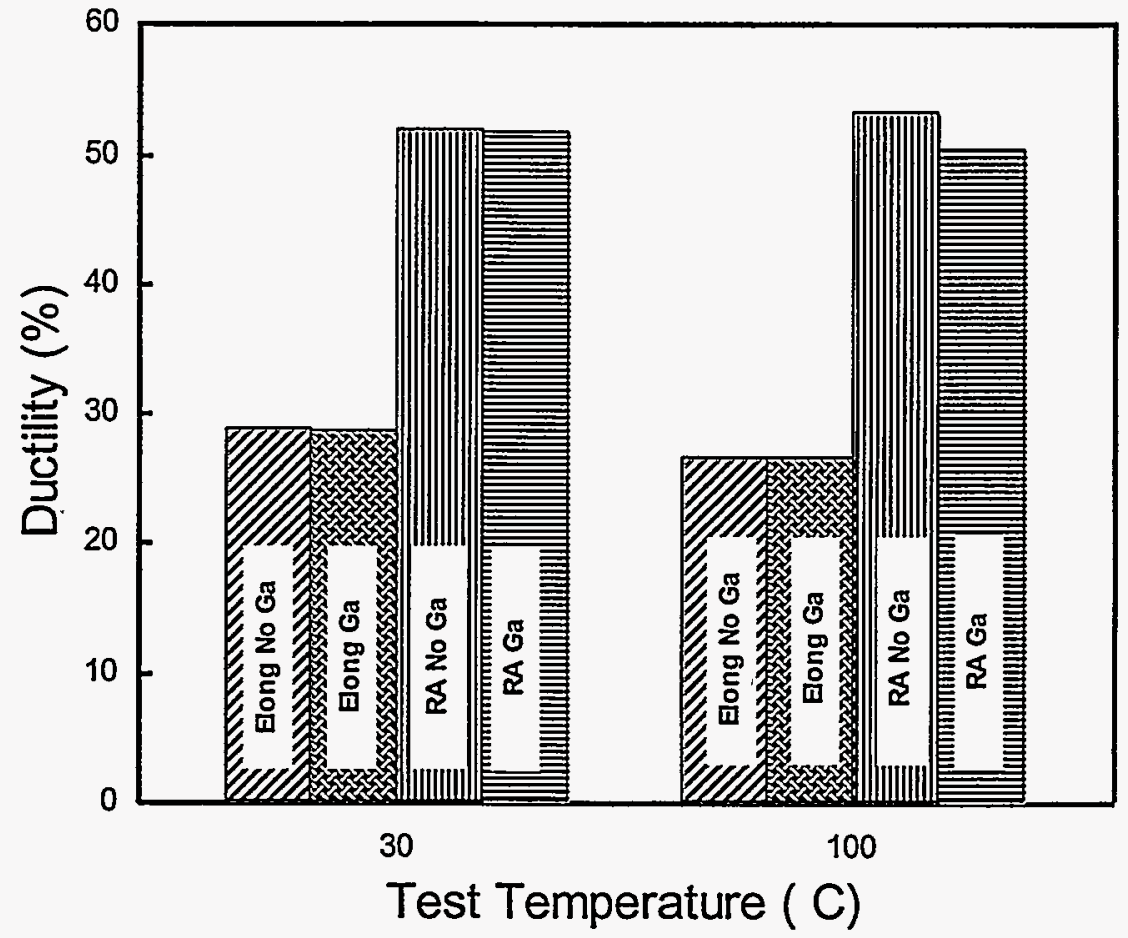

Fig. 15. LME tests showed no significant difference in ductility for Zircaloy $B$ at 30 and $100^{\circ} \mathrm{C}$. Elong, elongation; RA, reduction in cross sectional area. 


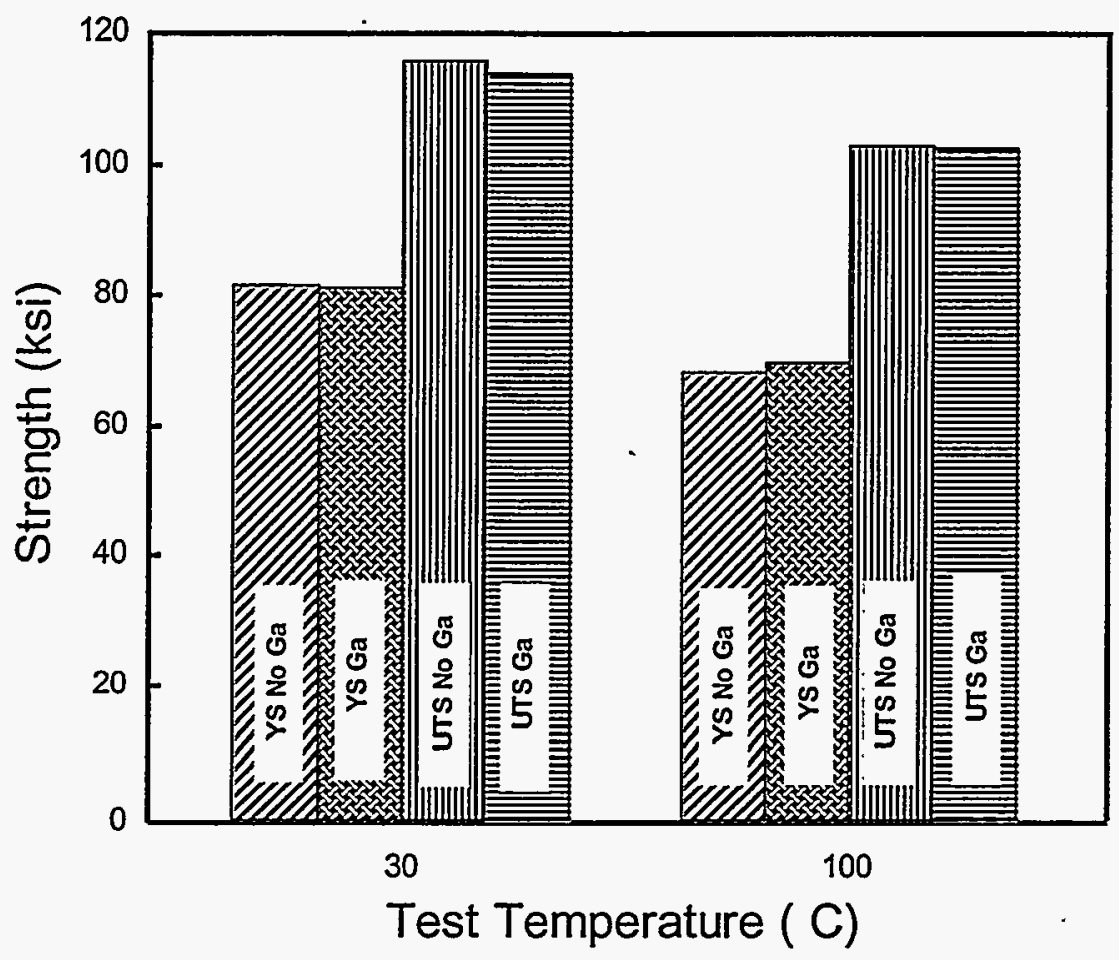

Fig. 16. LME test showed no change in strength for Zircaloy $\mathbf{C}$ at 30 and $100^{\circ} \mathrm{C}$. YS, yield strength; UTS, ultimate tensile strength.

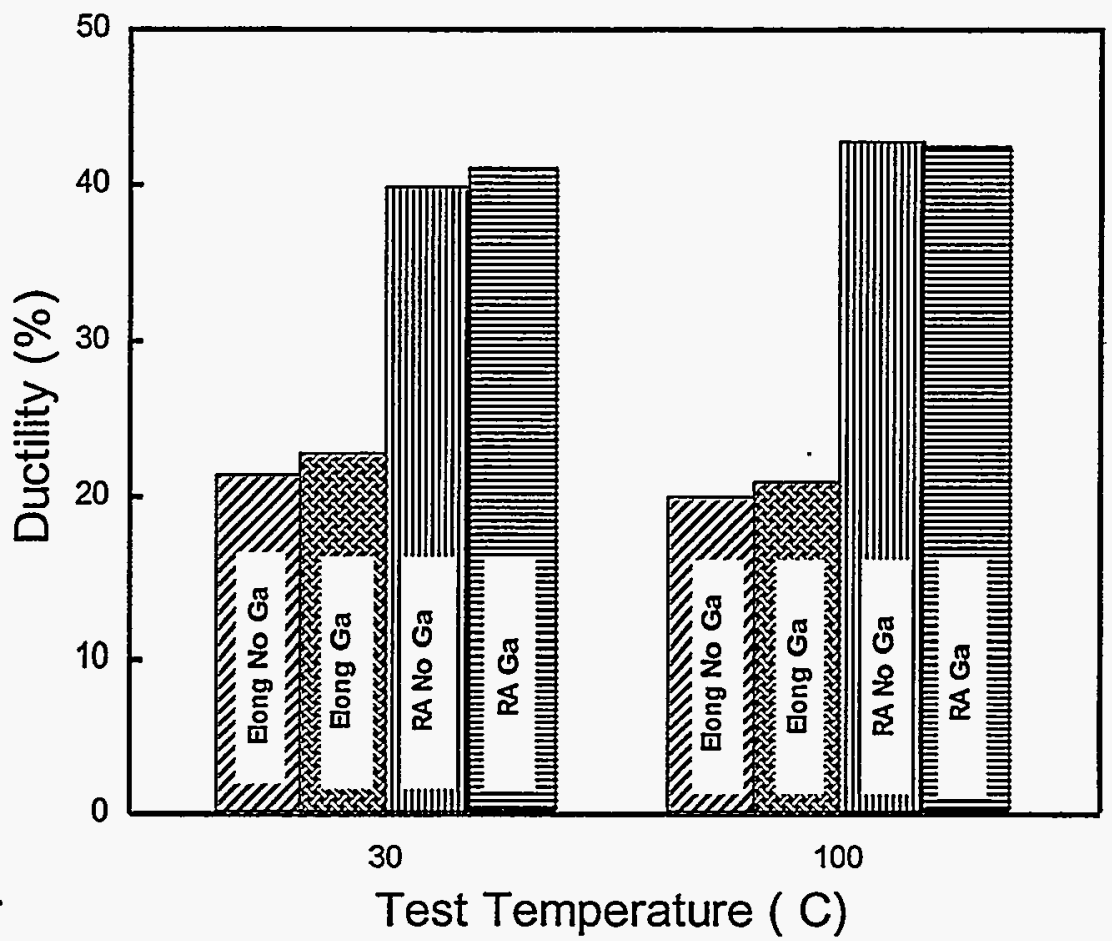

Fig. 17. LME tests showed no significant difference in ductility for Zircaloy $\mathrm{C}$ at 30 and $100^{\circ} \mathrm{C}$. Elong, elongation; RA, reduction in cross sectional area. 

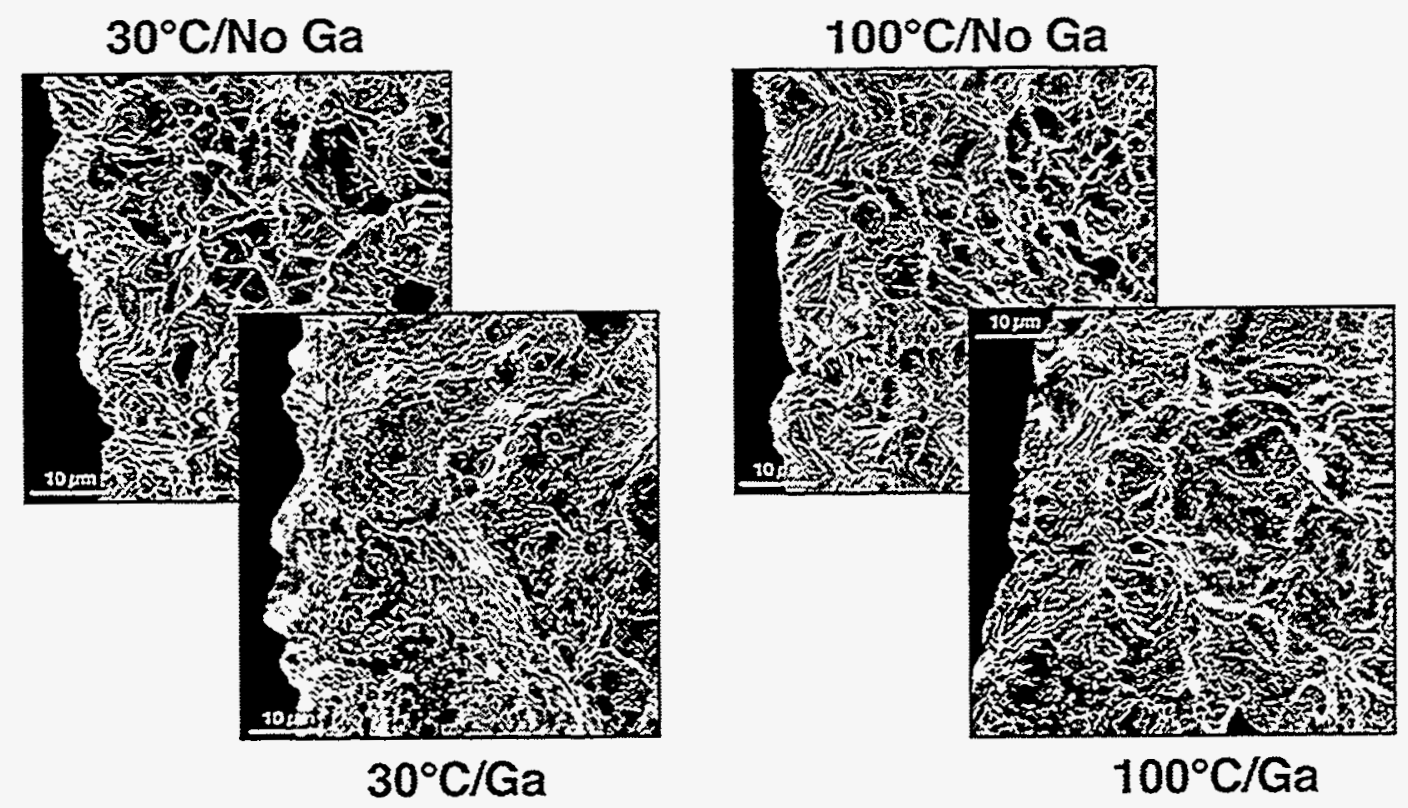

Fig. 18. Ductile failure mode at 30 and $100^{\circ} \mathrm{C}$ with and without gallium.

\subsubsection{Corrosion-Mechanical Tests}

The purpose of these tests was to obtain some measure of the effect of ICF on the mechanical properties of Zircaloy. The $\mathrm{Zr}_{x} \mathrm{Ga}_{y} \mathrm{IC}$ is quite hard and brittle; therefore, significant (and unrealistically large) quantities of ICF would be expected to markedly affect the mechanical properties of the Zircaloy. Furthermore, as reported previously, distortion of Zircaloy at $500^{\circ} \mathrm{C}$ became a complicating factor. Based on prior data from the corrosion tests, exposure of the Zircaloy to gallium for $30 \mathrm{~h}$ at $300^{\circ} \mathrm{C}$ was ultimately selected as the condition for the corrosion portion of the corrosion-mechanical tests. Under these conditions, most of the gallium did not react with the Zircaloy; however, a thin, intermittent area of ICF was present along the gage length of the Zircaloy capsule specimen. CERT tests $\left(8.33 \times 10^{-4} / \mathrm{s}\right)$ were conducted at room temperature and at $300^{\circ} \mathrm{C}$. The results (average of three specimens per material, per condition) are shown in Figs. 19 and 20 and indicate very little, if any, effect of the formation of small amounts of ICF on the mechanical properties of Zircaloy. In addition, examination of the fracture surfaces did not indicate any significant difference in the mode of failure (Fig. 21). 


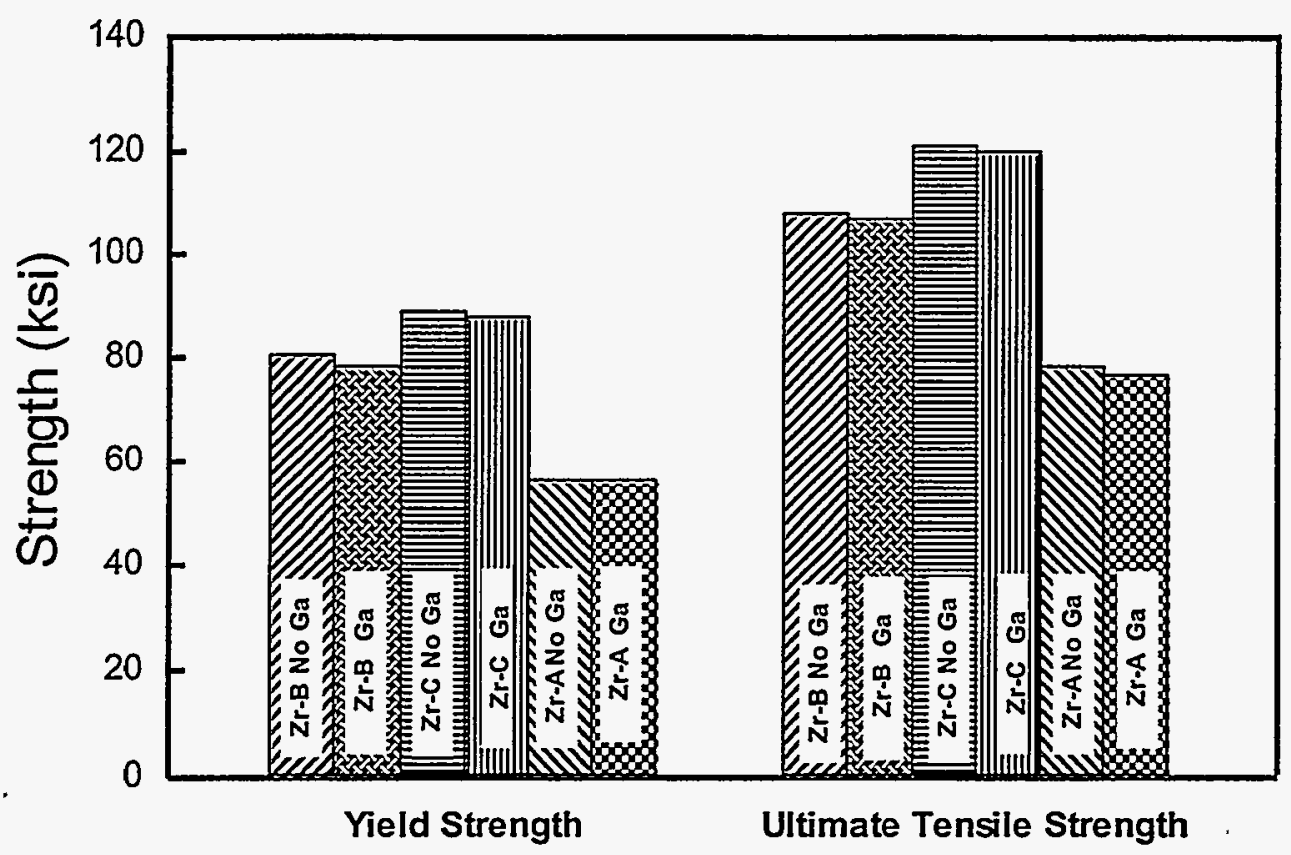

Fig. 19. No change in strength observed after reaction with gallium for $30 \mathrm{~h}$ at $300^{\circ} \mathrm{C}$.

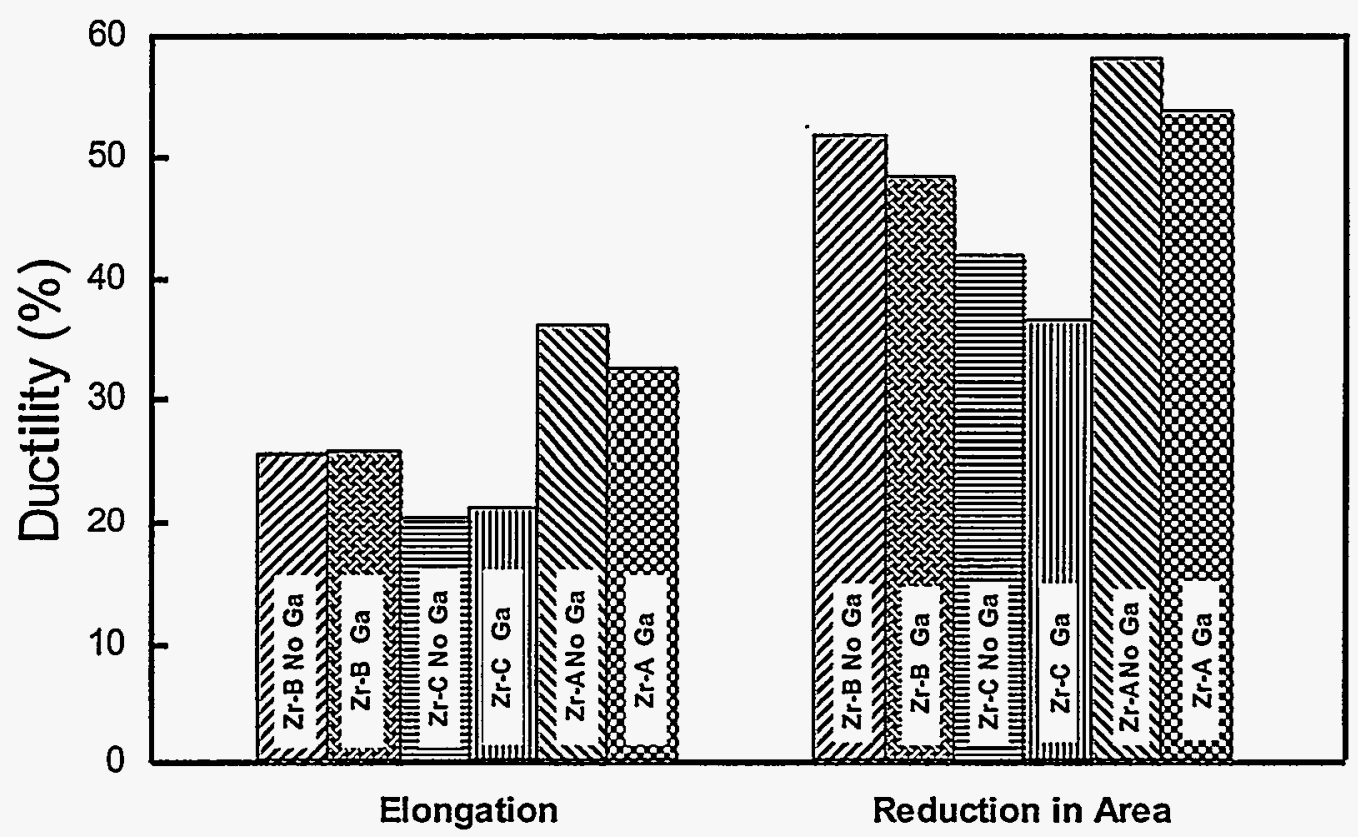

Fig. 20. No significant change in ductility observed after exposure to gallium for $30 \mathrm{~h}$ at $300^{\circ} \mathrm{C}$ 


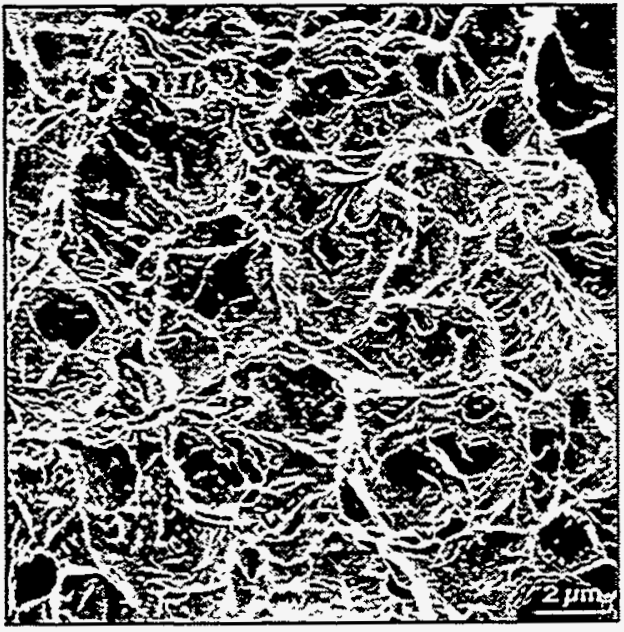

No Gallium

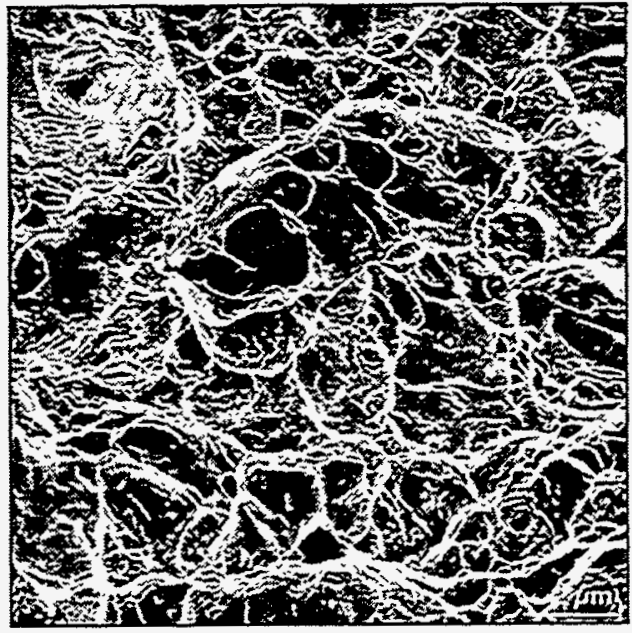

Gallium

Fig. 21. Ductile fracture observed after $30 \mathrm{~h}$ at $300^{\circ} \mathrm{C}$ without and with gallium. Specimen mechanically tested at room temperature.

\subsection{PHASE II}

\subsubsection{Corrosion Tests}

Corrosion tests in nonprototypic, powder mixtures containing $\mathrm{Ga}_{2} \mathrm{O}_{3}$ were conducted at 300,500 , and $700^{\circ} \mathrm{C}$ for 6 and 12 weeks. $\mathrm{Ce}_{2} \mathrm{O}_{3}$ powder was mechanically blended with $\mathrm{Ga}_{2} \mathrm{O}_{3}$ powder to produce mixtures that contained $100,1,0.2,0.1$, and $0 \mathrm{wt} \% \mathrm{Ga}_{2} \mathrm{O}_{3}$ to assess the effect of the concentration of gallium present during the exposures. Before initiating these tests, several surrogate oxides (for $\mathrm{PuO}_{2}$ ) were tested at 500 or $700^{\circ} \mathrm{C}$ with Zircaloy: $\mathrm{ZrO}_{2}, \mathrm{CaO}$, and $\mathrm{Ce}_{2} \mathrm{O}_{3}$, as well as $\mathrm{Ga}_{2} \mathrm{O}_{3}$. In all cases, as would also occur with $\mathrm{PuO}_{2}{ }^{1}$ an oxide layer was found on the inner surface of the Zircaloy that was qualitatively identified as $\mathrm{ZrO}_{2}$ (Fig. 22).

In the matrix tests, there were significant differences among results at the three temperatures. At $300^{\circ} \mathrm{C}$, no significant reaction was noted except for very slight surface roughening, even after the 12 -week exposures (Fig. 23). At $500^{\circ} \mathrm{C}$, the oxide layer mentioned previously was observed in all of the tests (Fig. 24). The thickness of the oxide layer was independent of $\mathrm{Ga}_{2} \mathrm{O}_{3}$ concentration and did not appreciably increase with time between 6 and 12 weeks. A visually distinguishable zone can be noted below the oxide layer. Although this zone was larger for the tests with $100 \% \mathrm{Ga}_{2} \mathrm{O}_{3}$, there was no appreciable difference among $1,0.2$, and $0.1 \% \mathrm{Ga}_{2} \mathrm{O}_{3}$ exposures. 

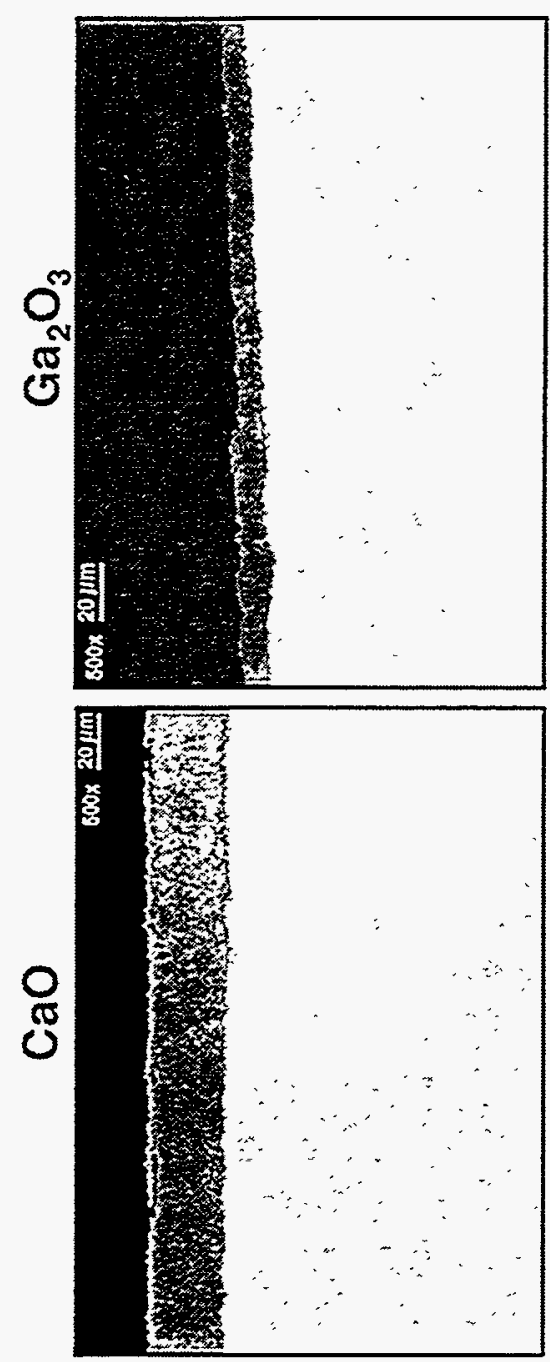

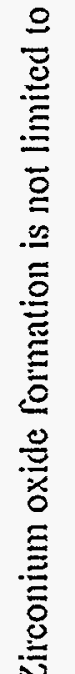

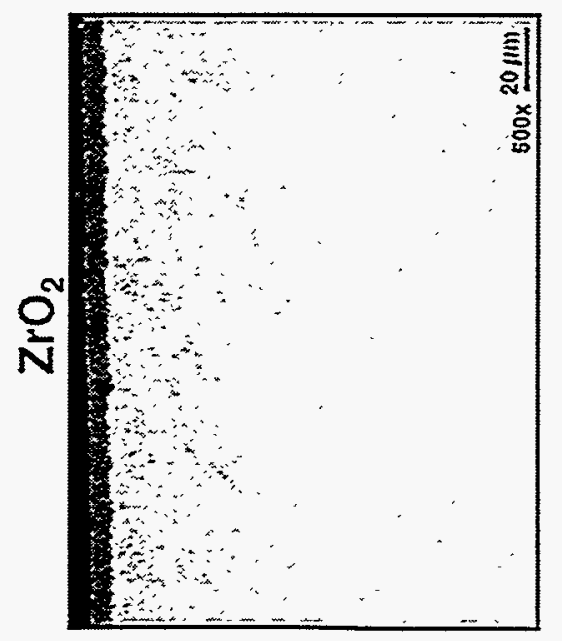

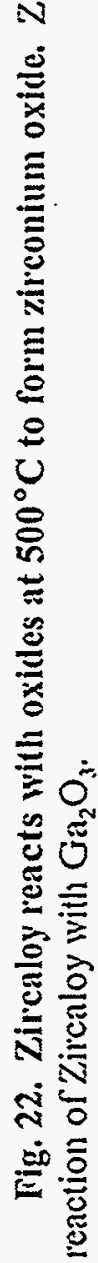




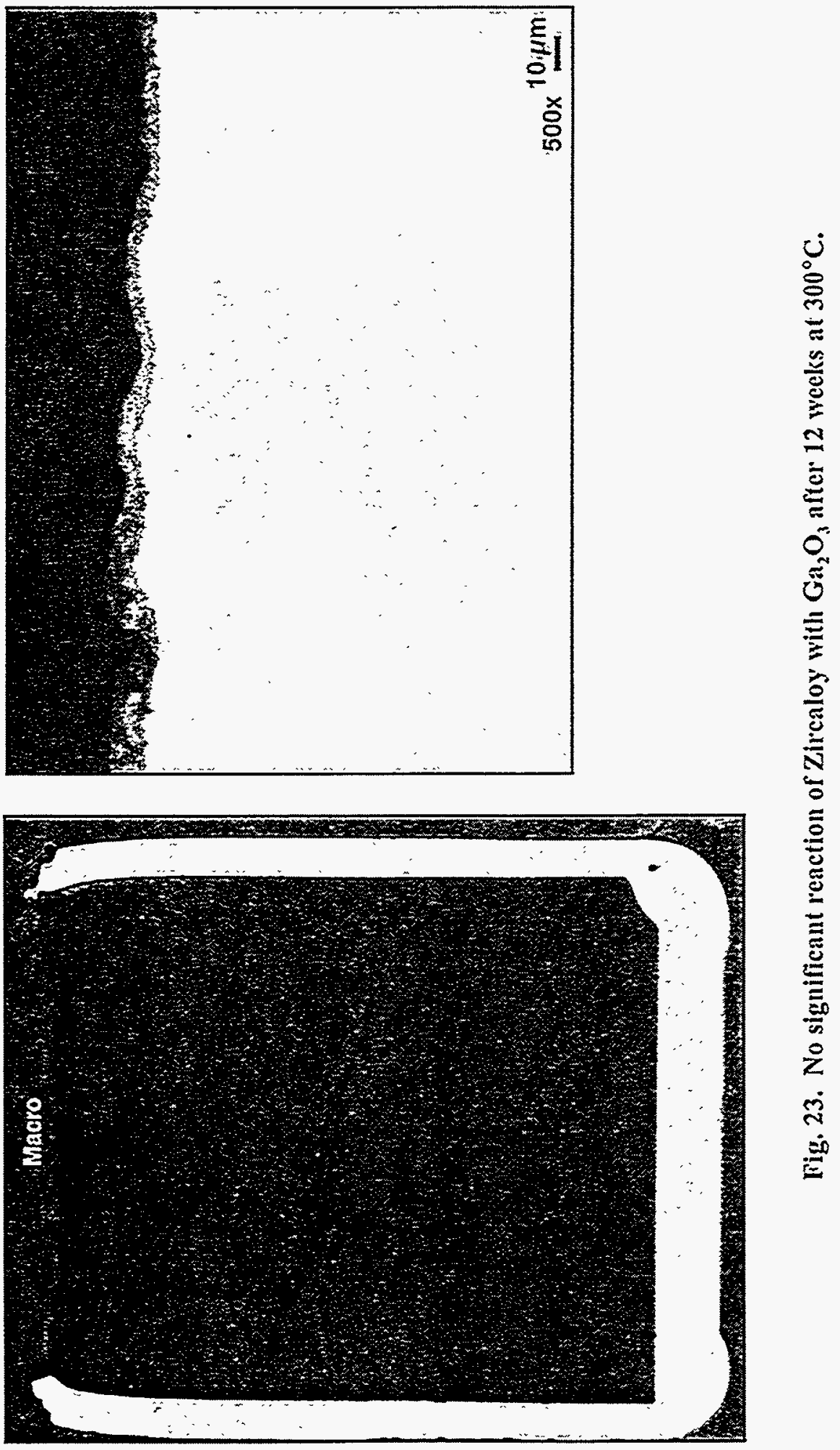



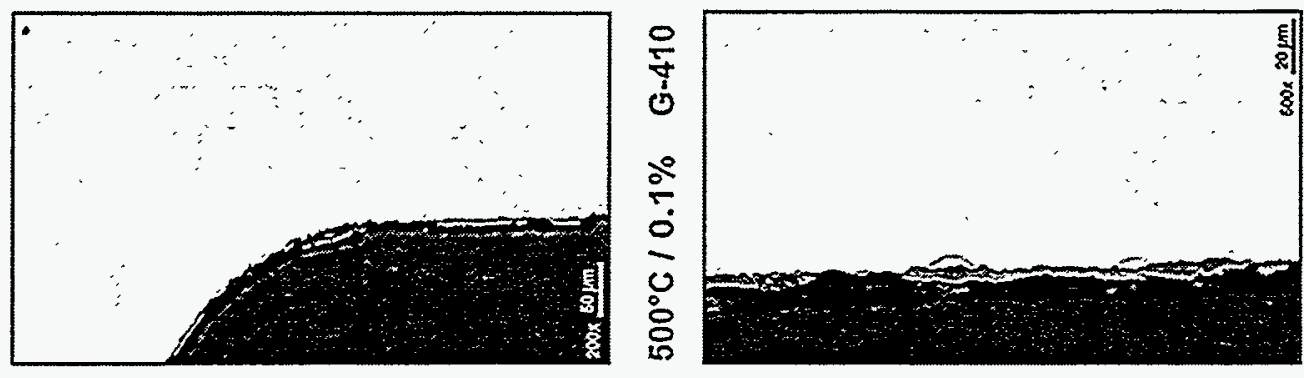

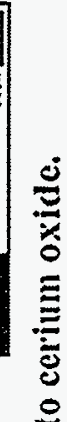
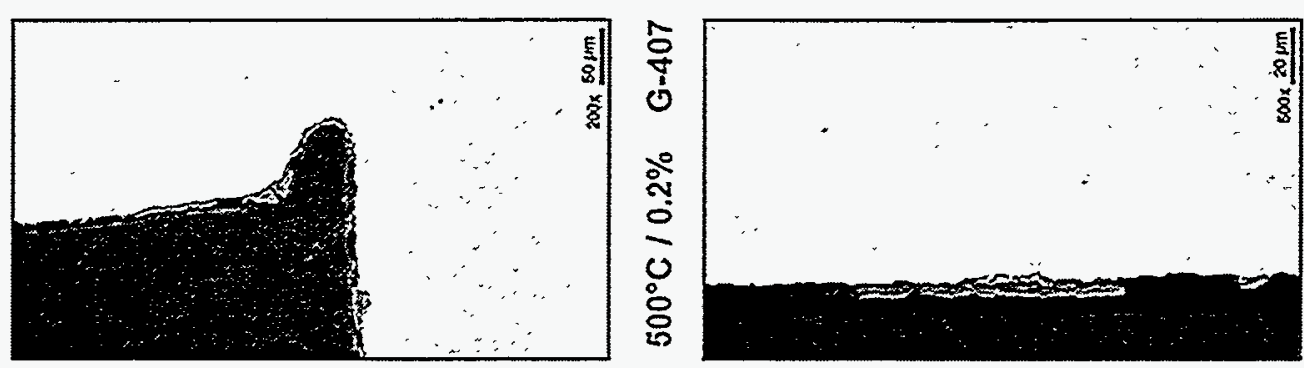

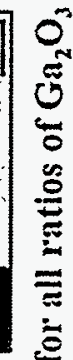
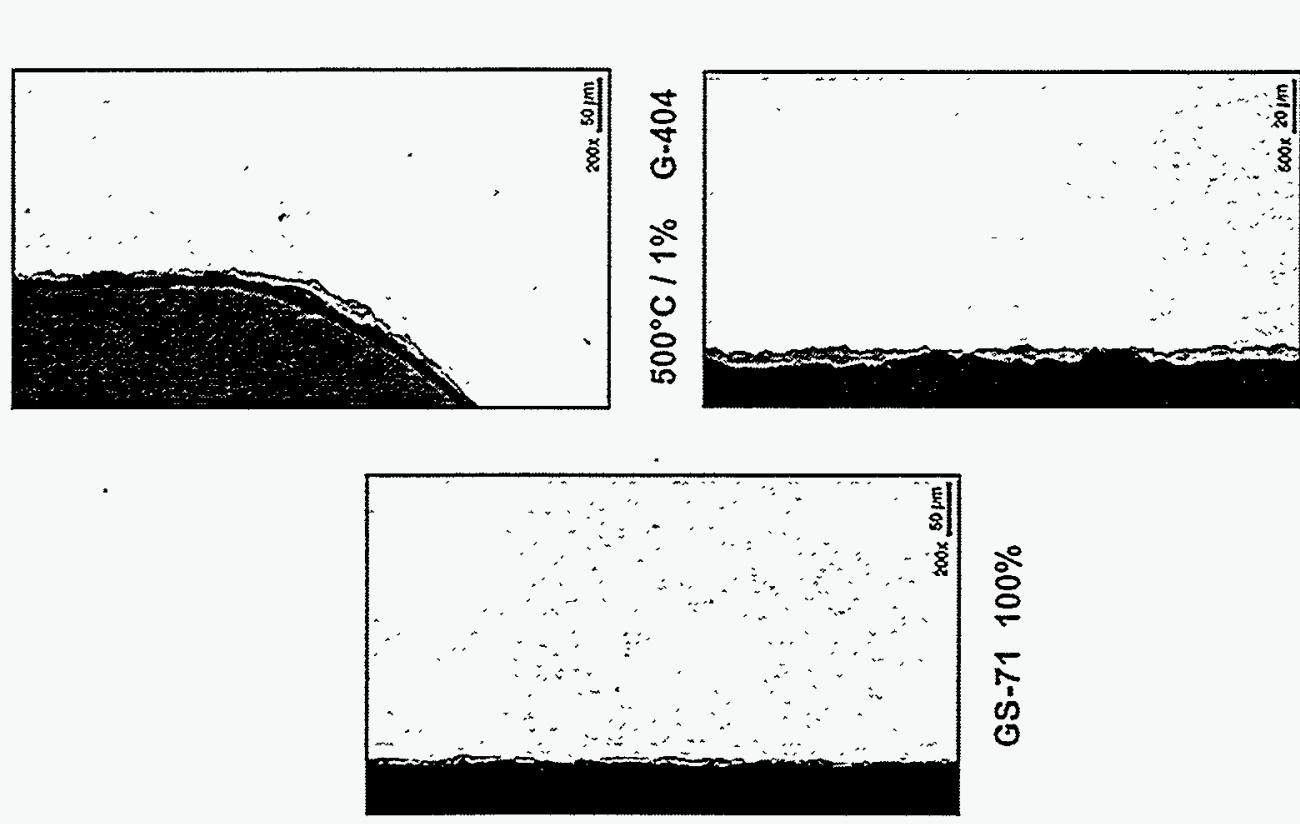

\&े
ஸे
ஸे

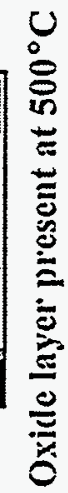

함

电 
At $700^{\circ} \mathrm{C}$, there was formation of an oxide layer on the inner surface of the Zircaloy and an identifiable gallium-rich zone below the oxide layer. The thickness of both the oxide and gallium-rich zone increased with time, but the gallium-rich zone was visible only with $100 \%$ $\mathrm{Ga}_{2} \mathrm{O}_{3}$ (Fig. 25). Another feature not seen at $500^{\circ} \mathrm{C}$ is cracking of the Zircaloy. Generally, testing at $700^{\circ} \mathrm{C}$ resulted in a somewhat uniform distortion of the Zircaloy tubing, and the cracks may be associated with an oxygen-enriched zone. 

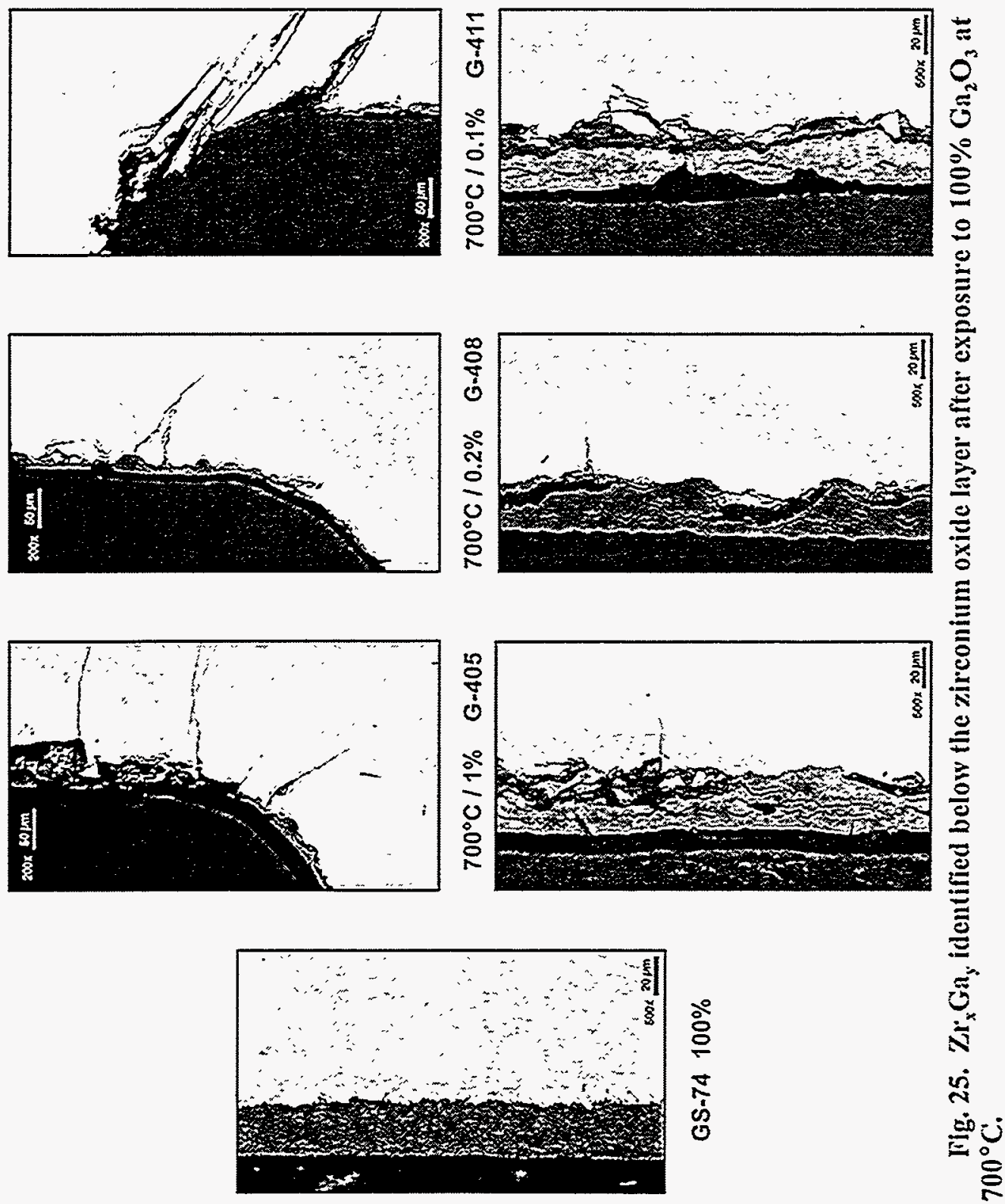


\subsubsection{Corrosion-Mechanical Tests}

This portion of the testing program was aimed at determining the effect of exposures at 300 and $500^{\circ} \mathrm{C}$ of Zircaloy to oxide powders containing $\mathrm{Ga}_{2} \mathrm{O}_{3}$. Mechanical tests were not conducted after exposure at $700^{\circ} \mathrm{C}$ due to distortion (caused by creep) of the test specimens.

\subsubsection{Room-Temperature Mechanical Tests}

The results of CERT tests $\left(8.33 \times 10^{-4} / \mathrm{s}\right)$, conducted at room temperature, are shown in Figs. 26 to 31 . There was either a slight change or no change in the room-temperature tensile properties (three specimens per condition) of any of the Zircaloy materials after exposure at $300^{\circ} \mathrm{C}$, as would have been predicted based on the corrosion test results reported previously. Similarly, after exposure at $500^{\circ} \mathrm{C}$, there was little change in the room-temperature properties as a function of $\mathrm{Ga}_{2} \mathrm{O}_{2}$ concentration, but both room temperature yield and ultimate tensile strength (Figs. 28 and 30 ) were lower than at $300^{\circ} \mathrm{C}$ for two of the three Zircaloys for all $\mathrm{Ga}_{2} \mathrm{O}_{3}$ concentrations, with a corresponding increase in ductility as measured by elongation and reduction in area (Figs. 29 and 31). After exposure at $500^{\circ} \mathrm{C}$, one of the Zircaloys had properties similar to those exhibited at $300^{\circ} \mathrm{C}$ except that ductility trended lower with exposure to powders with higher $\mathrm{Ga}_{2} \mathrm{O}_{3}$ (Figs. 26 and 27). Control tests indicated that these changes are a result of heat treatment at $500^{\circ} \mathrm{C}$ instead of the test environment. Before heat treatment at $500^{\circ} \mathrm{C}$, the alloys (Zircaloys B and C) shown in Figs. 28 to 31 had room-temperature tensile properties similar to those shown for heat treating/exposure to oxide powder at $300^{\circ} \mathrm{C}$. Thus, the heat treatment of these alloys at $500^{\circ} \mathrm{C}$ reduced their strength and increased their ductility. The properties of Zircaloy A (Fig. 26) were little changed by the $500^{\circ} \mathrm{C}$ heat treatment. 


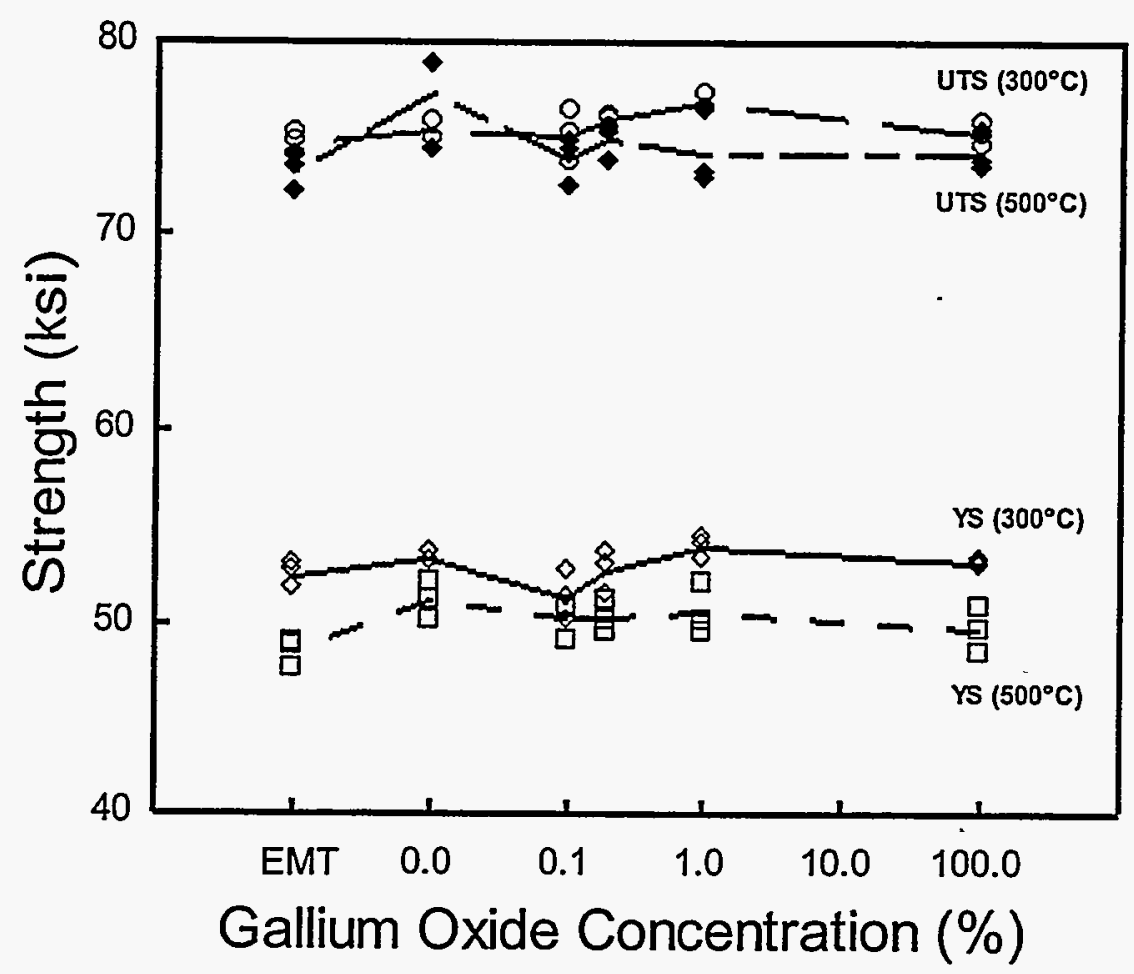

Fig. 26. No significant change in room-temperature strength for Zircaloy $A$ after exposure to $\mathrm{Ga}_{2} \mathrm{O}_{3}$ in cerium oxide ( 6 weeks at 300 and $500^{\circ} \mathrm{C}$ ). YS, yield strength; UTS, ultimate tensile strength; EMT, empty.

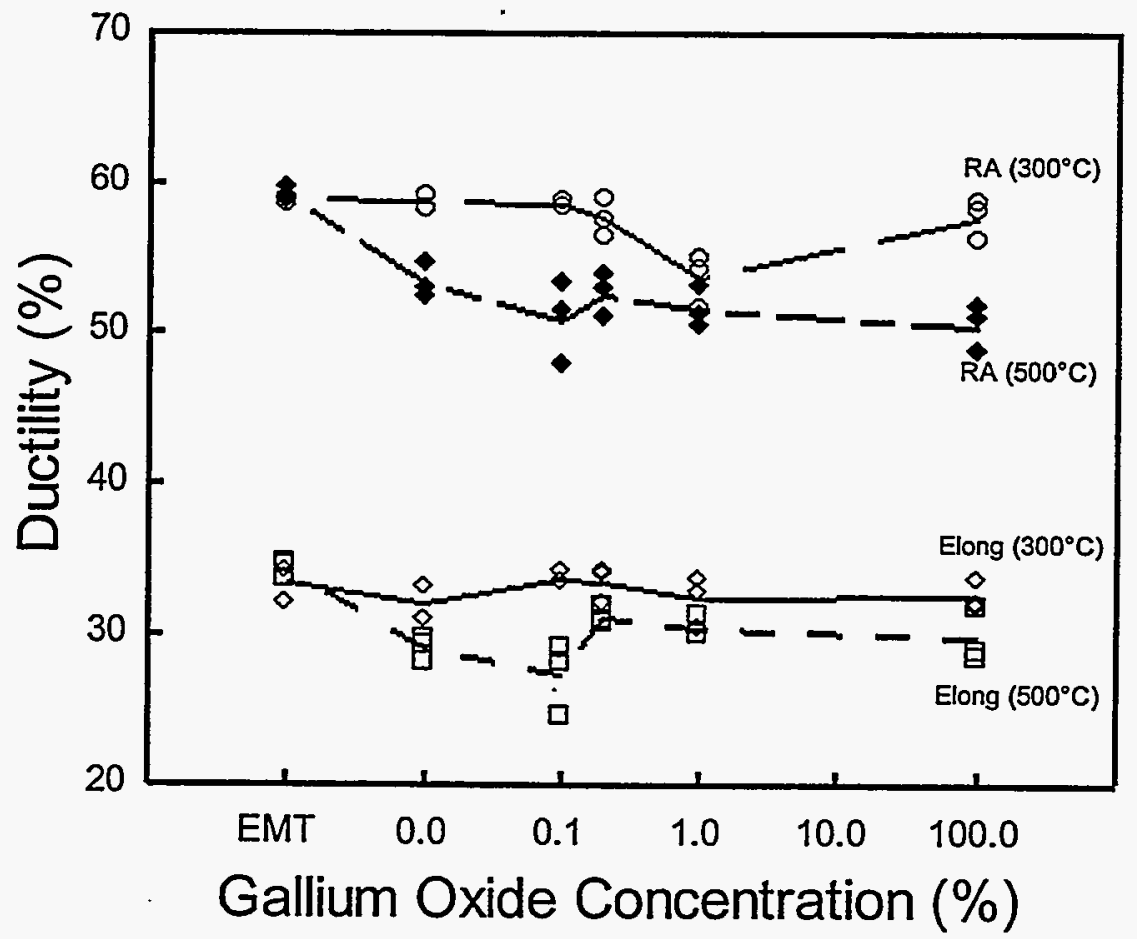

Fig. 27. Slight change in room-temperature ductility for Zircaloy $A$ after exposure to $\mathrm{Ga}_{2} \mathrm{O}_{3}$ in cerium oxide $\left(6\right.$ weeks at 300 and $500^{\circ} \mathrm{C}$ ). Elong, elongation; RA, reduction in cross-sectional area; EMT, empty. 


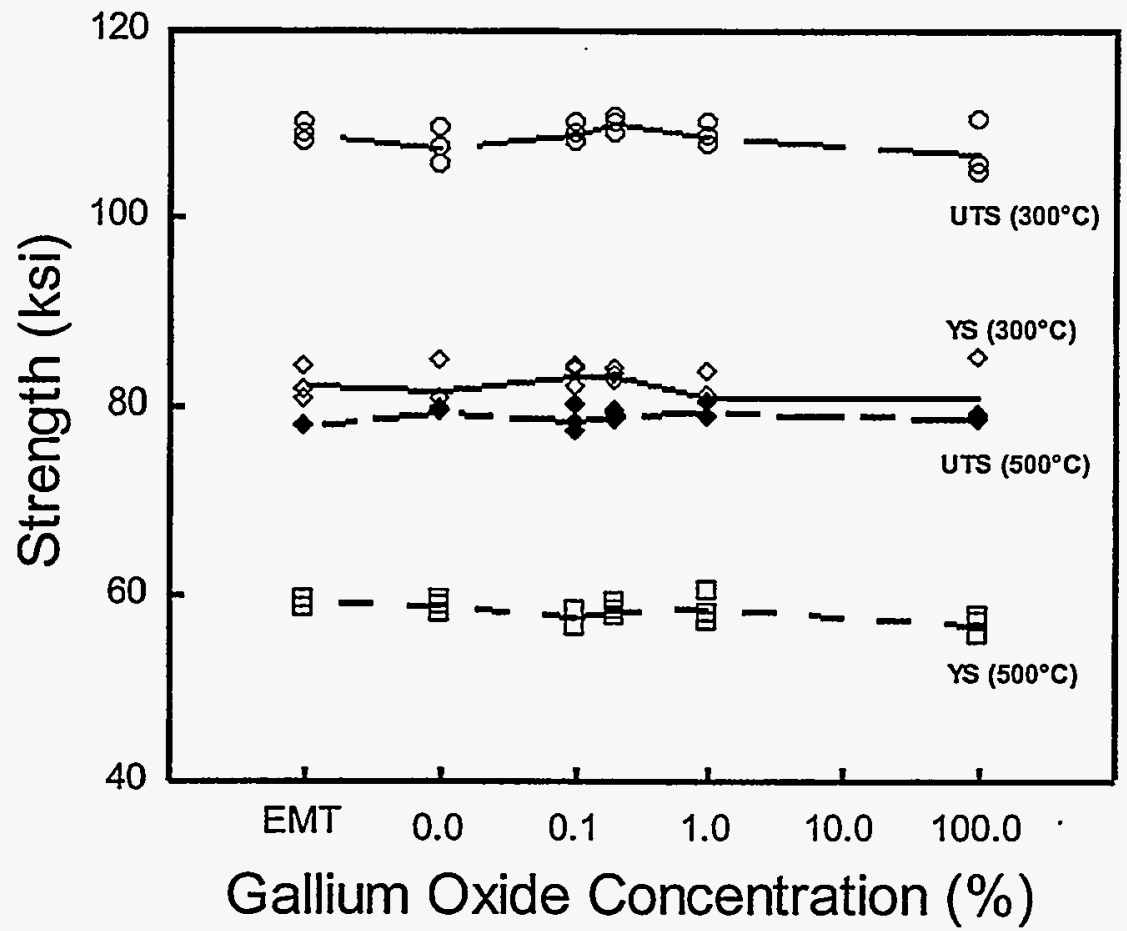

Fig. 28. No significant change in room-temperature strength for Zircaloy $B$ after exposure to $\mathrm{Gà}_{2} \mathrm{O}_{3}$ in cerium oxide (6 weeks at 300 and $500^{\circ} \mathrm{C}$ ). YS, yield strength; UTS, ultimate tensile strength; EMT, empty.

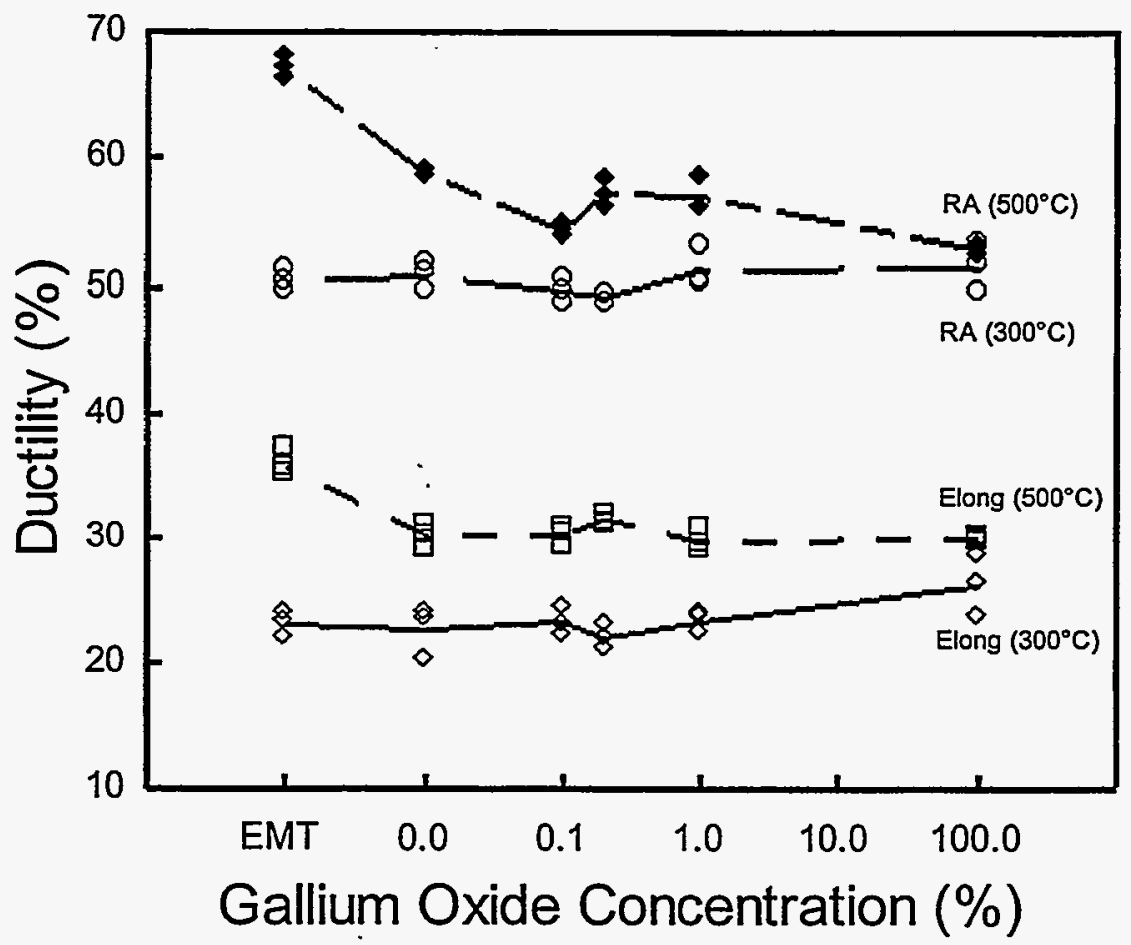

Fig. 29. Slight change in room-temperature ductility for Zircaloy $B$ after exposure to $\mathrm{Ga}_{2} \mathrm{O}_{3}$ in cerium oxide $\left(6\right.$ weeks at 300 and $500^{\circ} \mathrm{C}$ ). Elong, elongation; RA, reduction in cross-sectional area; EMT, empty. 


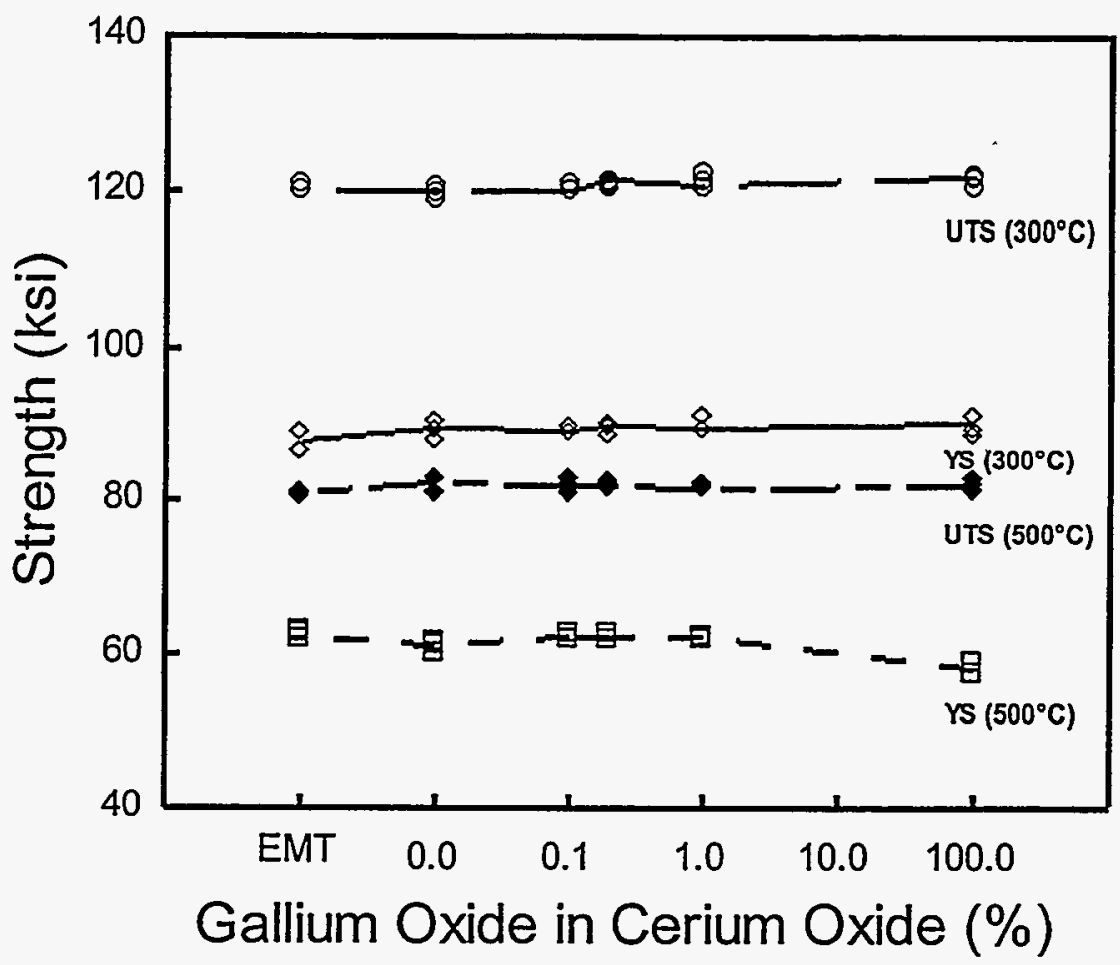

Fig. 30. No significant change in room-temperature strength for Zircaloy $\mathrm{C}$ after exposure to $\mathrm{Ga}_{2} \mathrm{O}_{3}$ in cerium oxide (6 weeks at 300 and $500^{\circ} \mathrm{C}$ ). YS, yield strength; UTS, ultimate tensile strength; EMT, empty.

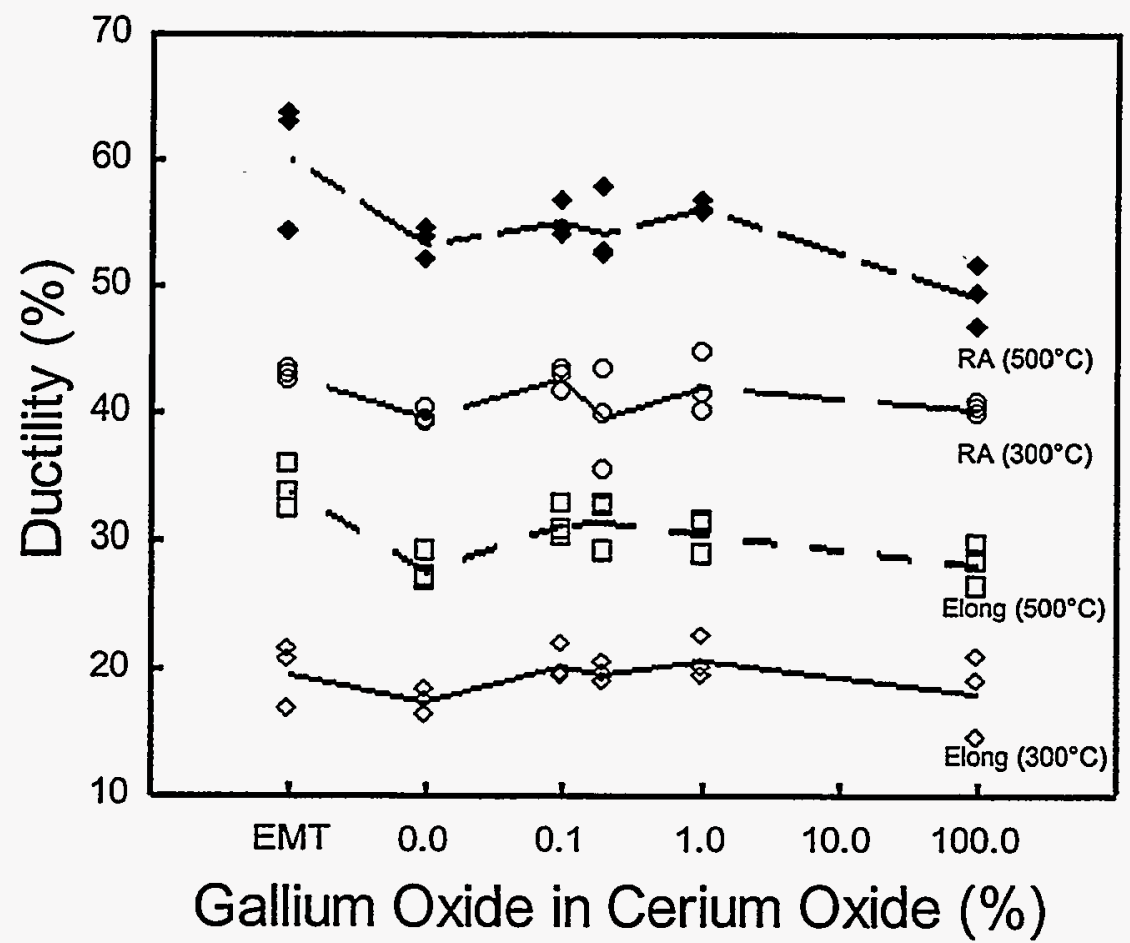

Fig. 31 . Slight change in room-temperature ductility for Zircaloy $\mathrm{C}$ after exposure to $\mathrm{Ga}_{2} \mathrm{O}_{3}$ in cerium oxide $\left(6\right.$ weeks at 300 and $500^{\circ} \mathrm{C}$ ). Elong, elongation; RA, reduction in cross-sectional area; EMT, empty. 


\subsubsection{High-Temperature Mechanical Tests}

CERT tests $\left(8.33 \times 10^{-4} / \mathrm{s}\right)$ were conducted at 300 and $500^{\circ} \mathrm{C}$. As shown in Fig. 32, there is little, if any, change in the $300^{\circ} \mathrm{C}$ strength and ductility properties (two specimens per condition) of Zircaloy $A$ as a result of exposure to various concentration of $\mathrm{Ga}_{2} \mathrm{O}_{3}$. The mechanical properties of specimens after exposure are very similar to those for the heat-treated (without oxide) specimens. Compared with the room-temperature properties, the $300^{\circ} \mathrm{C}$ strength values are, as expected, lower and the ductility values are, as expected, slightly higher.

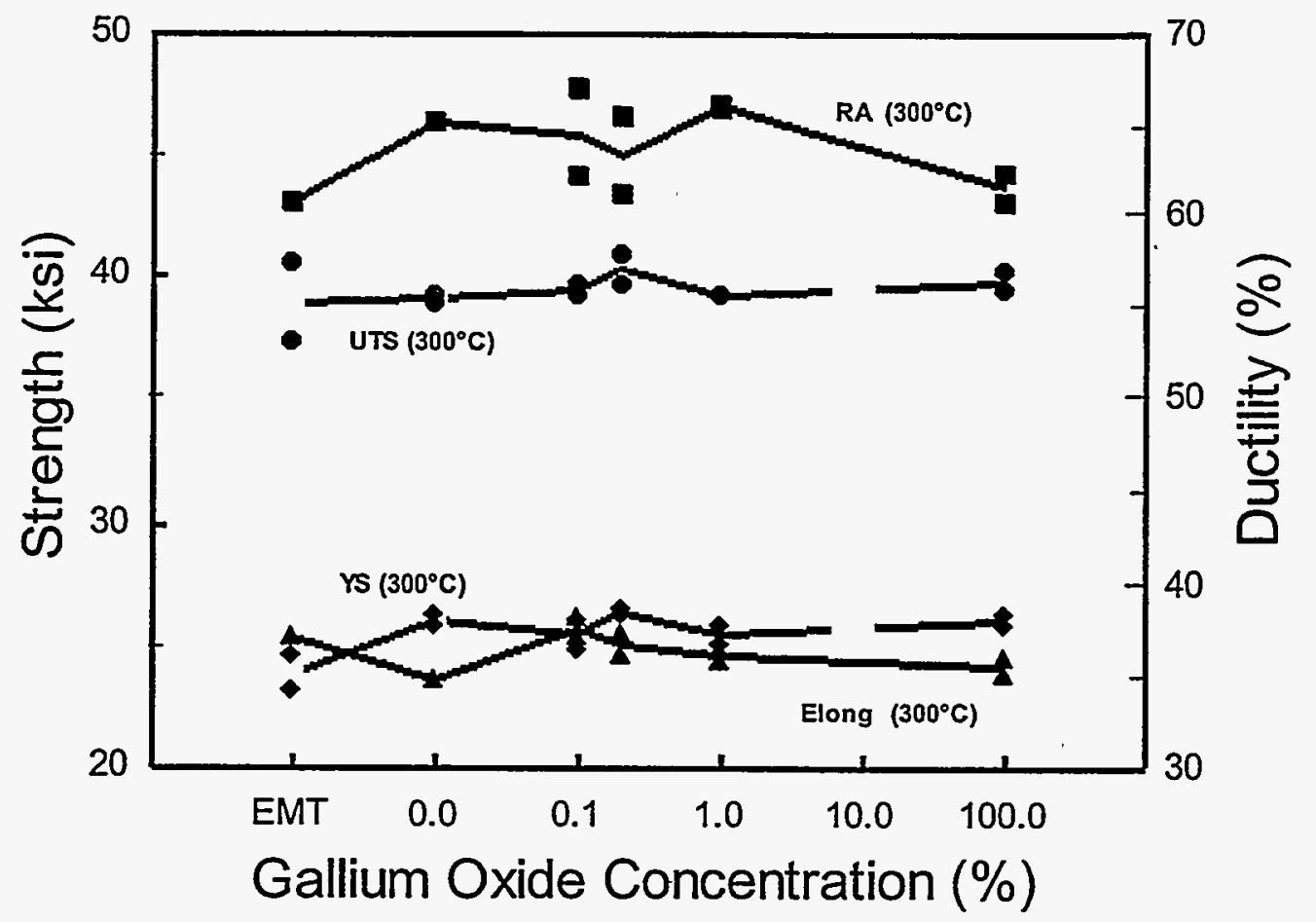

Fig. 32. No significant changes in $300^{\circ} \mathrm{C}$ strength and ductility for Zircaloy $\mathrm{A}$ after exposure to $\mathrm{Ga}_{2} \mathrm{O}_{3}$ in cerium oxide $\left(6\right.$ weeks at $\left.300^{\circ} \mathrm{C}\right)$. YS, yield strength; UTS, ultimate tensile strength; Elong, elongation; RA, reduction in cross-sectional area; EMT, empty.

As shown in Fig. 33, there is little, if any, change in the $500^{\circ} \mathrm{C}$ strength and ductility properties of Zircaloy $A$ as a result of exposure to various concentrations of $\mathrm{Ga}_{2} \mathrm{O}_{3}$. The mechanical properties of specimens after exposure are very similar to those for the $500^{\circ} \mathrm{C}$ heattreated (without oxide) specimens. Compared with the $300^{\circ} \mathrm{C}$ properties, the $500^{\circ} \mathrm{C}$ strength values are, as expected, lower and the ductility values are, as expected, slightly higher. 


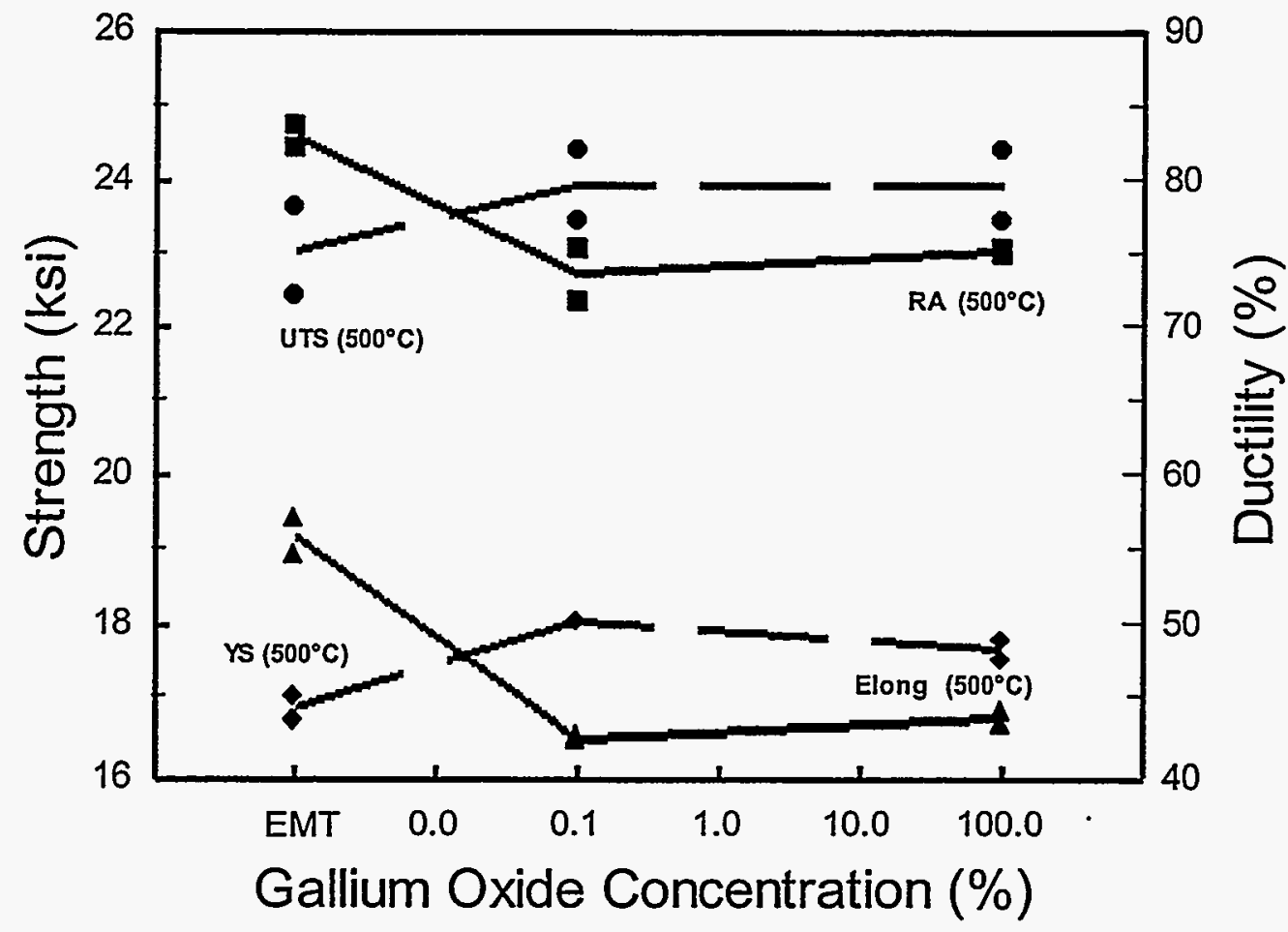

Fig. 33. No significant changes in $500^{\circ} \mathrm{C}$ strength and ductility for Zircaloy $\mathrm{A}$ after exposure to $\mathrm{Ga}_{2} \mathrm{O}_{3}$ in cerium oxide $\left(6\right.$ weeks at $\left.500^{\circ} \mathrm{C}\right)$. YS, yield strength; UTS, ultimate tensile strength; Elong, elongation; RA, reduction in cross-sectional area; EMT, empty.

Behavior similar to Zircaloy A was observed for the mechanical properties (two specimens per condition) of Zircaloy $\mathrm{C}$ at 300 and $500^{\circ}$ (Figs. 34 and 35). While data were not obtained for Zircaloy B, it can be inferred that, within the limitations of 6-week tests, the hightemperature mechanical properties of Zircaloy materials are not affected by exposure to $\mathrm{Ga}_{2} \mathrm{O}_{3}$. The only effect that would be observed is due to time at temperature. 


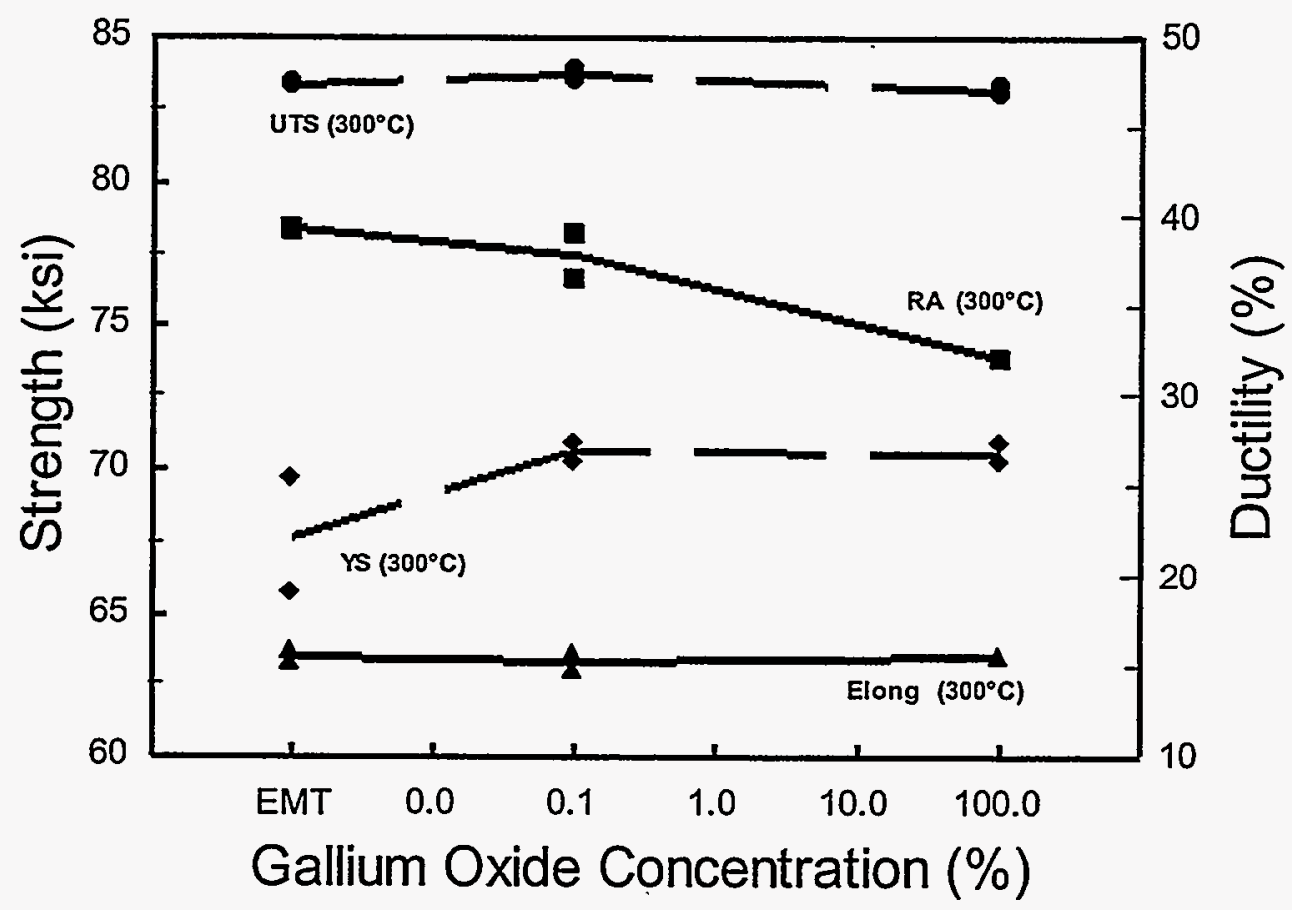

Fig. 34. No significant changes in $300^{\circ} \mathrm{C}$ strength and ductility for Zircaloy $\mathrm{C}$ after exposure to $\mathrm{Ga}_{2} \mathrm{O}_{3}$ in cerium oxide $\left(6\right.$ weeks at $\left.300^{\circ} \mathrm{C}\right)$. YS, yield strength; UTS, ultimate tensile strength; Elong, elongation; RA, reduction in cross-sectional area; EMT, empty.

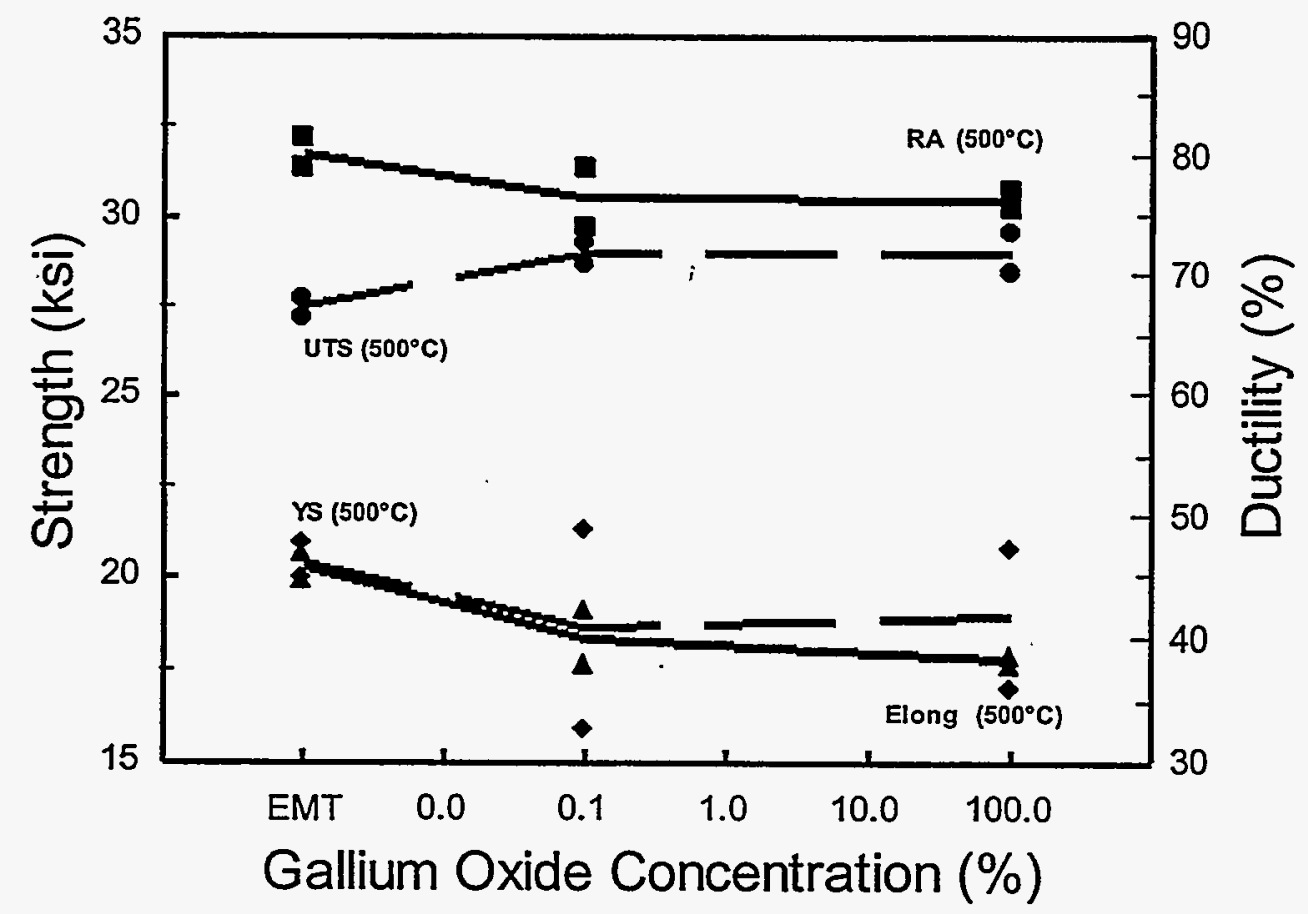

Fig. 35. No significant changes in $500^{\circ} \mathrm{C}$ strength and ductility for Zircaloy $\mathrm{C}$ after exposure to $\mathrm{Ga}_{2} \mathrm{O}_{3}$ in cerium oxide $\left(6\right.$ weeks at $500^{\circ} \mathrm{C}$ ). YS, yield strength; UTS, ultimate tensile strength; Elong, elongation; RA, reduction in cross-sectional area; EMT, empty. 


\section{DISCUSSION}

Liquid gallium is highly reactive with most metals since it readily alloys with elemental components that are in many structural materials. For example, gallium forms intermetallic compounds with iron, nickel, chromium, cobalt, vanadium, and zirconium. Even though these elements have limited solubility in gallium at temperatures as high as $\sim 500^{\circ} \mathrm{C}$, they would not be suitable for use in structural materials to contain gallium above $300^{\circ} \mathrm{C}$ because of their chemical conversion to ICs of the form $M_{x} G a_{y}$, where $M_{x}$ refers to a metallic element. However, in the present application, in which the total amount of gallium in a 3.66-m (12-ft) fuel pin is expected to be $\sim 0.02 \mathrm{~g}$, formation of ICs would be very limited. If in the unlikely event that all of the gallium present in a fuel pin were to reach the cladding interface in one location, only a very small amount of the cladding wall would be converted to ICs and the effect on tensile properties will be slight to negligible. These studies have also shown no embrittlement of Zircaloy caused by either classic LME effects from liquid gallium or reactions that result in the formation of small amounts of ICF or an oxide layer on the Zircaloy.

LME is a phenomenon similar to stress corrosion cracking that can occur with certain liquid metal-solid metal combinations. However, the kinetics and mechanisms of LME are not clearly understood. One explanation is that chemisorption of the liquid reduces bond cohesion at the surface, ${ }^{14,15}$ or that chemisorption creates dislocations at the tip of a crack that subsequently interact with the dislocation structure in the plastic zone leading to further microcracking. ${ }^{16,17}$ Wetting by the liquid metal and the presence of a tensile stress are necessary for LME to occur, but if the component elements form stable, high-melting-point compounds, severe LME is unlikely. ${ }^{18,19}$ Because zirconium readily forms a series of ICs with gallium at temperatures to $800^{\circ} \mathrm{C}$, its resistance to LME is not surprising.

On the other hand, ICF results in conversion of zirconium in Zircaloy to a brittle intermetallic phase, which could affect the mechanical properties of the cladding. However, after reaction at $300^{\circ} \mathrm{C}$ to form a thin layer of IC on the inner diameter surface of the Zircaloy (but more than expected in a fuel pin), there was no effect on the tensile properties. When a similar experiment was conducted at $350^{\circ} \mathrm{C}$ and the thickness of the IC increased, a modest loss in ductility was found. This finding further supports a conclusion that gallium effects are mass limited.

The distortion that results from ICF appears to be related to stresses that develop in the wall of some Zircaloy tubing during interalloying. In preliminary tests at 400 to $600^{\circ} \mathrm{C}$ with either pure zirconium or nonvendor supplied Zircaloy II, no distortion was noted with quantities of liquid gallium that later caused distortion in two of the three vendor-supplied materials. 
Differences associated with the type of Zircaloy tested were the appearance of much more porosity in the outer IC that formed and less cracking of the inner IC where distortion was not observed. In the materials where distortion occurred, the IC was more dense and exhibited numerous cracks usually in a direction perpendicular to the wall. As the quantity of gallium available to react with the Zircaloy was reduced, distortion was eliminated. For small quantities of gallium at $\geq 350^{\circ} \mathrm{C}$, the liquid gallium is quickly consumed to locally form IC, thus ending the reaction. However, when additional (excess) gallium is available, further reaction can occur as the zirconium and gallium continue to react. It is very likely that liquid gallium either diffuses through the first IC that forms or reaches the metal-IC interface via cracks in the IC. It is during this process that stresses likely develop and lead to distortion. It is well known from oxidation studies that certain volume ratios of corrosion product (oxide) to metal can lead to tensile stresses in the metal. ${ }^{20}$

Most probably, though not certainly, gallium will be present in MOX fuel as an oxide rather than in metallic form. 'In corrosion tests involving oxides $\left(\mathrm{Ga}_{2} \mathrm{O}_{3}, \mathrm{Ce}_{2} \mathrm{O}_{3}, \mathrm{CaO}\right.$, or $\left.\mathrm{ZrO}_{2}\right)$ in contact with Zircaloy, formation of zirconium oxide at the metal-oxide interface was found at $500^{\circ} \mathrm{C}$. With $\mathrm{Ga}_{2} \mathrm{O}_{3}$, gallium was present below the oxide at $500^{\circ} \mathrm{C}$. At $700^{\circ} \mathrm{C}, \mathrm{Zr}_{x} \mathrm{Ga}_{y}$ was identified below the oxide. Because zirconium forms a very stable oxide (Fig. 36), oxide formation on the fuel cladding inner diameter surface is likely, although the rate of formation at temperatures below $500^{\circ} \mathrm{C}$ is unknown (e.g., at $300^{\circ} \mathrm{C}$ there was very slight indication of oxide formation after 12 weeks).

The room-temperature, 300 , and $500^{\circ} \mathrm{C}$ tensile test results after exposure to oxide $\left(\mathrm{Ga}_{2} \mathrm{O}_{3}\right.$ in $\mathrm{Ce}_{2} \mathrm{O}_{3}$ ) for 6 weeks at 300 or $500^{\circ} \mathrm{C}$ (temperatures that bracket the expected LWR clad normal operating temperature of $\sim 400^{\circ} \mathrm{C}$ ) do not appear to indicate any appreciable effect of concentration of $\mathrm{Ga}_{2} \mathrm{O}_{3}$ on strength or ductility. Two of the Zircaloy materials showed significant changes in room-temperature properties from heat treatment at $500^{\circ} \mathrm{C}$. However, but there were no further effects attributable to exposure to the various concentrations of $\mathrm{Ga}_{2} \mathrm{O}_{3}$ for 6 weeks. 


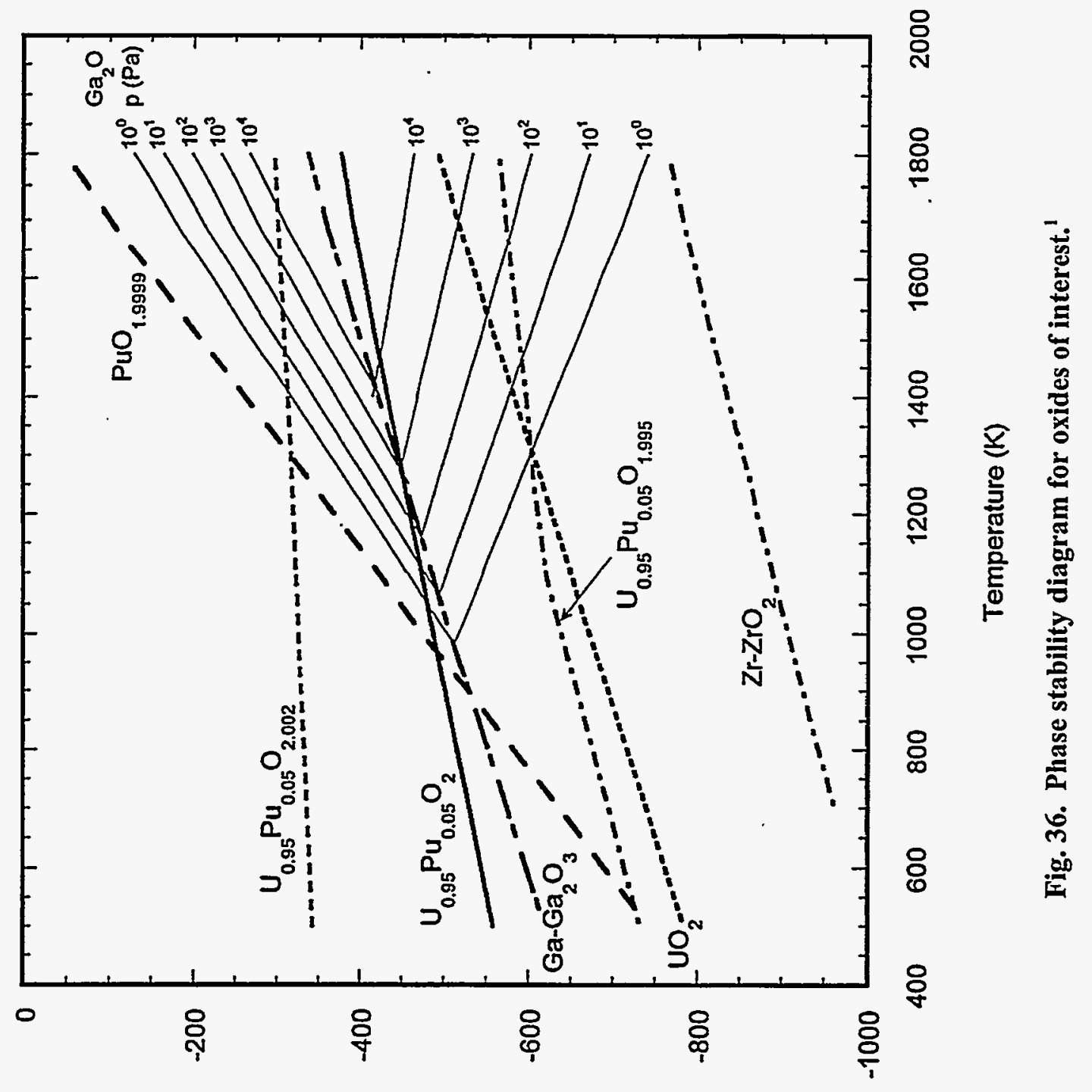

$\left(\right.$ (ow/ry) $\left(^{2} \mathrm{O}\right)_{*} \mathrm{~d}$ ul $\perp y$ 



\section{CONCLUSIONS}

\subsection{PHASE I}

Corrosion testing revealed that liquid gallium reacts with Zircaloy to form an IC of the form $\mathrm{Zr}_{\mathrm{x}} \mathrm{Ga}_{\mathrm{y}}$. The extent of reaction is a function of temperature, but more importantly, is strongly dependent on the amount of gallium involved. Although distortion of some Zircaloys can be a by-product of ICF at $>300^{\circ} \mathrm{C}$, distortion in susceptible materials at $500^{\circ} \mathrm{C}$ did not occur at ratios of weight of gallium to surface area of Zircaloy that were $10^{4}$ to $10^{5}$ higher than those expected with WG-MOX fuel in an LWR fuel pin. Mechanical property testing after corrosion exposure to form a thin IC layer on the gage section of Zircaloy specimens further confirmed that there should be little effect of small quantities of gallium in MOX fuel on the Zircaloy cladding.

No localized corrosion effects were found. In the corrosion tests (up to $500^{\circ} \mathrm{C}$ ), there was no evidence of grain boundary attack in addition to ICF. In the LME tests at 30 and $100^{\circ} \mathrm{C}$, there was no change in the tensile properties when Zircaloy was tested in liquid gallium and the fracture remained ductile.

\subsection{PHASE II}

Results of testing in $\mathrm{Ga}_{2} \mathrm{O}_{3}$ or $\mathrm{Ce}_{2} \mathrm{O}_{3}-\mathrm{Ga}_{2} \mathrm{O}_{3}$ mixtures did not indicate any significant effects at $300^{\circ} \mathrm{C}$. At $500^{\circ} \mathrm{C}$, an oxide layer formed on the Zircaloy and room-temperature tensile tests for two of the materials showed a loss in strength with a corresponding increase in ductility. The oxide layer also formed during exposure of Zircaloy to several other oxide powders, making it uncertain whether any of the observed mechanical effects are related to the presence of gallium.

At $700^{\circ} \mathrm{C}$, which is considerably above LWR operating temperatures, there was evidence of reduction of $\mathrm{Ga}_{2} \mathrm{O}_{3}$ by Zircaloy and formation of a gallium-rich corrosion product below the ubiquitous oxide layer. However, this gallium-rich zone was not confirmed in tests with $<100 \%$ $\mathrm{Ga}_{2} \mathrm{O}_{3}$.

Based on the results obtained, it does not appear that 1 to $10 \mathrm{ppm}$ gallium in MOX fuel will have any measurable effect on the properties of Zircaloy cladding. 


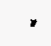




\section{REFERENCES}

1. D. F. Wilson et al., Potential Effects of Gallium on Cladding Materials, ORNL/TM-13504, Lockheed Martin Energy Research Corp., Oak Ridge Natl. Lab., 1997.

2. D. F. Wilson et al., Interactions of Zircaloy Cladding with Gallium 1997 Status, ORNL/TM13505, Lockheed Martin Energy Research Corp., Oak Ridge Natl. Lab., 1997.

3. D. F. Wilson et al., Interactions of Zircaloy Cladding with Gallium: 1998 Midyear Status, ORNL/TM-13625, Lockheed Martin Energy Research Corp., Oak Ridge Natl. Lab., 1998.

4. T. B. Massalski, ed., Binary Alloy Phase Diagrams 2, ASM International, Metals Park, Ohio, 1990, p. 1880.

5. H. S. Rosenbaum, Electrochemical Technology 4, 153 (1966).

6. H. S. Rosenbaum, J. H. Davies, and J. Q. Pon, EURAEC Report, GEAP 5100-5105, 1966.

7. W. T. Grubb, "Cadmium Embrittlement of Zircaloy-2 and Certain Other Metals and Alloys," pp. 473-484 in Embrittlement by Liquid and Solid Metals, ed. M. H. Kamdar, The Metallurgical Society of AIME, Warrendale, Penn., 1984.

8. R. P. Gangloff, "Solid Cadmium Embrittlement of Textured Zircaloy-2," pp. 485-505 in Embrittlement by Liquid and Solid Metals, ed. M. H. Kamdar, The Metallurgical Society of AIME, Warrendale, Penn., 1984.

9. B. Cox, Environmentally Induced Cracking of Zirconium Alloys: II-Liquid Metal Embrittlement, AECL-3612, Atomic Energy of Canada, Ontario, Canada, 1970.

10. T. Watanabe, S. Shima, and S. Karashima, "Liquid Metal Gallium Induced Intergranular Fracture of Aluminum Bicrystals," pp. 173-182 in Embrittlement by Liquid and Solid Metals, ed. M. H. Kamdar, The Metallurgical Society of AIME, Warrendale, Penn., 1984.

11. H. Ichinose and T. Takashima, "Grain Boundary Diffusion and Static Fatigue of Aluminum by Liquid Gallium," pp. 197-210 in Embrittlement by Liquid and Solid Metals, ed. M. H. Kamdar, The Metallurgical Society of AIME, Warrendale, Penn., 1984.

12. W. T. Grubb and M. H. Morgan III, "A Survey of Chemical Environments for Activity in the Embrittlement of Zircaloy-2," pp. 145-154 in Proceedings of the Fourth International Conference: Zirconium in the Nuclear Industry, ASTM STP 681, American Society for Testing and Materials, Philadelphia, 1979.

13. H. R. Trellue et al., Nuclear Fuels Technologies Fiscal Year 1997 Research and Development Test Results, LA-UR-97-4423, Univ. of Calif., Los Alamos Natl. Lab., 1997.

14. A. R. C. Westwood and R. M. Latanision, "Adsorption-Induced Embrittlement by Liquid Metals," pp. 405-415 in Proceedings of Corrosion by Liquid Metals, ed. J. E. Draly and J. R. Weeks, The Metallurgical Society of AIME, Philadelphia, 1969.

15. N. S. Stoloff and T. L. Johnson, Acta Met. 11, 251 (1963).

16. V. V. Popovich, Phys. Chem. Mech. Materials, USSR 5 (1979). 
17. S. P. Lynch, Acta Met. 36, 2639 (1988).

18. W. Rostoker, J. M. McCaughey and H. Markus, Embrittlement by Liquid Metals, Reinhold, New York, New York, 1960.

19. V. I. Likhtman, E. D. Shchukin, and P. A. Rebinder, Physicochemical Mechanics of Metals, Academy of Sciences, USSR 1962.

20. N. B. Pilling and R. E. Bedworth, J. Inst. Metals, 29, 529 (1923). 


\section{APPENDIX}

The following tables summarize the status of the work performed. Nonvendor-supplied materials are listed with their trade names. Vendor-supplied materials are listed with generic names.

Table A.1. Supplemental compatibility tests of zirconium/Zircaloy with gallium or $\mathrm{Ga}_{2} \mathrm{O}_{3}$ in support of test design

\begin{tabular}{|c|c|c|c|c|}
\hline Material & $\begin{array}{c}\text { Test } \\
\text { environment }\end{array}$ & $\begin{array}{l}\text { Temp. } \\
\left({ }^{\circ} \mathrm{C}\right)\end{array}$ & $\begin{array}{c}\text { Time } \\
\text { (h) }\end{array}$ & Comments \\
\hline $\mathrm{Zr}$ & $\mathrm{Ga}$ & 400 & 100 & Intermetallic compound formation (ICF) \\
\hline $\mathrm{Zr}$ & $\mathrm{Ga}$ & 600 & 134 & ICF \\
\hline Zircaloy-2 & $\mathrm{Ga}$ & 400 & 100 & ICF \\
\hline Zircaloy-2 & $\mathrm{Ga}$ & 600 & 100 & ICF \\
\hline Zircaloy-2 & $\mathrm{Ga}_{2} \mathrm{O}_{3}$ & 400 & 200 & Thin $\mathrm{ZrO}_{2}$ layer visible at $1000 \mathrm{X}$ \\
\hline Zircaloy-2 & $\mathrm{Ga}_{2} \mathrm{O}_{3}$ & 600 & 200 & Slightly thicker $\mathrm{ZrO}_{2}$ layer visible at $1000 \mathrm{X}$ \\
\hline Zircaloy-2 & $\mathrm{Ga}_{2} \mathrm{O}_{3}$ & 500 & 672 & $\mathrm{ZrO}_{2}$ layer plus $\mathrm{Ga}$ within alloy \\
\hline Zircaloy-2 & $\mathrm{Ga}_{2} \mathrm{O}_{3}$ & 500 & 2016 & $\begin{array}{l}\mathrm{ZrO}_{2} \text { layer plus } \mathrm{Ga} \text { within alloy; no change } \\
\text { in thickness (compared with } 4 \text { weeks) }\end{array}$ \\
\hline Zircaloy -4 & $\mathrm{Ga}_{2} \mathrm{O}_{3}$ & 700 & 672 & $\begin{array}{l}\text { Much thicker } \mathrm{ZrO}_{2} \text { layer (compared with } \\
500^{\circ} \mathrm{C} \text { ), plus ICF below oxide; cracks in } \\
\mathrm{ZrO}_{2}\end{array}$ \\
\hline Zircaloy-4 & $\mathrm{Ga}_{2} \mathrm{O}_{3}$ & 700 & 2016 & $\begin{array}{l}\text { 4-mil } \mathrm{ZrO}_{2} \text { layer plus } 3 \text { mils of ICF below } \\
\text { oxide }\end{array}$ \\
\hline Zircaloy-B (veridor) & $\mathrm{Ga}$ & 500 & 200 & $\begin{array}{l}\text { Electron beam welding (EBW) (vacuum); } \\
\text { ICF; very slight distortion }\end{array}$ \\
\hline Zircaloy-C (vendor) & $\mathrm{Ga}$ & 500 & 200 & EBW (vacuum); ICF; distortion \\
\hline Zircaloy-B (vendor) & $\mathrm{Ga}$ & 500 & 200 & $\begin{array}{l}\text { Thin end cap ( } 0.50 \text { in.); ICF; very slight } \\
\text { distortion }\end{array}$ \\
\hline Zircaloy-B (vendor) & $\mathrm{Ga}$ & 500 & 200 & $\begin{array}{l}\text { Thick end cap ( } 0.2 \text { in.) with circumferential } \\
\text { laser beam welding (LBW) of end cap to } \\
\text { seal crevice; ICF; distortion }\end{array}$ \\
\hline Zircaloy-C (vendor) & $\mathrm{Ga}$ & 500 & 200 & Thin end cap; ICF; distortion \\
\hline Zircaloy-C (vendor) & $\mathrm{Ga}$ & 500 & 200 & Thick end cap with LBW; ICF; distortion \\
\hline Zircaloy-C (vendor) & $\mathrm{Ga}$ & 500 & 200 & $\sim 650 \mathrm{ppm} \mathrm{Ga}$ in $\mathrm{ZrO}_{2}$ powder \\
\hline Zircaloy-C (vendor) & $\mathrm{Ga}$ & 500 & 200 & $\begin{array}{l}\sim 650 \mathrm{ppm} \mathrm{Ga} \text { at bottom of capsule covered } \\
\text { with } \mathrm{ZrO}_{2} \text { powder }\end{array}$ \\
\hline Zircaloy-4 & $\mathrm{Ga}_{2} \mathrm{O}_{3}$ & 700 & 672 & $\begin{array}{l}\sim 1800 \text { ppm } \mathrm{Ga}_{2} \mathrm{O}_{3} \text { blended with } \mathrm{ZrO}_{2} \\
\text { interaction to }<0.5 \text { mil }\end{array}$ \\
\hline Zircaloy-C (vendor) & $\mathrm{ZrO}_{2}$ & 500 & 200 & $\mathrm{ZrO}_{2}$ as surrogate \\
\hline
\end{tabular}


Table A.1. Supplemental compatibility tests of zirconium/Zircaloy with gallium or $\mathrm{Ga}_{2} \mathrm{O}_{3}$ in support of test design

\begin{tabular}{|c|c|c|c|c|}
\hline Material & $\begin{array}{c}\text { Test } \\
\text { environment } \\
\end{array}$ & $\begin{array}{l}\text { Temp. } \\
\left({ }^{\circ} \mathrm{C}\right)\end{array}$ & $\begin{array}{c}\text { Time } \\
\text { (h) }\end{array}$ & Comments \\
\hline Zircaloy-C (vendor) & $\mathrm{CaO}$ & 500 & 200 & $\mathrm{CaO}$ as surrogate \\
\hline Zircaloy-B (vendor) & $\mathrm{Ce}_{2} \mathrm{O}_{3}$ & 500 & 200 & $\mathrm{Ce}_{2} \mathrm{O}_{3}$ as surrogate \\
\hline Zircaloy-B (vendor) & $\mathrm{Ga}$ & 500 & 200 & $\begin{array}{l}3 \mathrm{~g} \mathrm{Ga} \text {; evaluation of tungsten }(\mathrm{W}) \text { insert } \\
\text { geometry for liquid metal embrittlement } \\
\text { (LME) \& corrosion-mechanical (C-M) } \\
\text { tests }\end{array}$ \\
\hline Zircaloy-C (vendor) & $\mathrm{Ga}$ & 500 & 200 & $\begin{array}{l}3 \mathrm{~g} \mathrm{Ga} \text {; evaluation of } \mathrm{W} \text { insert geometry } \\
\text { for LME \& C-M tests }\end{array}$ \\
\hline Zircaloy-C (vendor) & - & & & $\begin{array}{l}\text { No insert; evaluation of specimen geometry } \\
\text { for LME \& C-M tests }\end{array}$ \\
\hline Zircaloy-C (vendor) & $\mathrm{Ga}$ & & & $\begin{array}{l}\text { Large insert; evaluation of } W \text { insert for } \\
\text { LME \& C-M tests }\end{array}$ \\
\hline Zircaloy-C (vendor) & $\mathrm{Ga}$ & & & $\begin{array}{l}\text { No insert; evaluation of specimen geometry } \\
\text { for LME \& C-M tests }\end{array}$ \\
\hline Zircaloy-C (vendor) & $\mathrm{Ga}$ & & & $\begin{array}{l}\text { Small insert; evaluation of } W \text { insert for } \\
L M E \text { and } C-M \text { tests }\end{array}$ \\
\hline Zircaloy-C (vendor) & $\mathrm{Ga}$ & 300 & 200 & $\begin{array}{l}\text { Determine acceptable, } f(\mathrm{~T} \text { ), (no swelling \& } \\
\text { very thin corrosion layer) corrosion } \\
\text { conditions for } \mathrm{C}-\mathrm{M} \text { tests }\end{array}$ \\
\hline Zircaloy-C (vendor) & $\mathrm{Ga}$ & 400 & 200 & $\begin{array}{l}\text { Determine acceptable, } f(T) \text {, (no swelling \& } \\
\text { very thin corrosion layer) corrosion } \\
\text { conditions for } C-M \text { tests }\end{array}$ \\
\hline Zircaloy-C (vendor) & $\mathrm{Ga}$ & 350 & 200 & $\begin{array}{l}\text { Determine acceptable, } f(\mathrm{~T}) \text {, (no swelling \& } \\
\text { very thin corrosion layer) corrosion } \\
\text { conditions for C-M tests }\end{array}$ \\
\hline Zircaloy-B (vendor) & $\mathrm{Ga}$ & 300 & 100 & $\begin{array}{l}\text { Determine acceptable, } f(\mathrm{t}) \text {, (no swelling \& } \\
\text { and very thin corrosion layer) corrosion } \\
\text { conditions for C-M tests }\end{array}$ \\
\hline Zircaloy-B (vendor) & $\mathrm{Ga}$ & 300 & 25 & $\begin{array}{l}\text { Determine acceptable, } f(t) \text {, (no swelling \& } \\
\text { very thin corrosion layer) corrosion } \\
\text { conditions for C-M tests }\end{array}$ \\
\hline Zircaloy-B (vendor) & $\mathrm{Ga}$ & 300 & 50 & $\begin{array}{l}\text { Determine acceptable, } f(t) \text {, (no swelling \& } \\
\text { very thin corrosion layer) corrosion } \\
\text { conditions for C-M tests }\end{array}$ \\
\hline Zircaloy-A (vendor) & $\mathrm{Ga}$ & 500 & 200 & Comparison of distortion, $f$ (material) \\
\hline Zircaloy-B (vendor) & $\mathrm{Ga}$ & 500 & 200 & Comparison of distortion, $f$ (material) \\
\hline Zircaloy-C (vendor) & $\mathrm{Ga}$ & 500 & 200 & Comparison of distortion, $f$ (material) \\
\hline Zircaloy-A (vendor) & $\mathrm{Ga} / \mathrm{Cd}$ & 500 & 200 & Comparison of distortion, $f$ (material) \\
\hline Zircaloy-B (vendor) & $\mathrm{Ga} / \mathrm{Cd}$ & 500 & 200 & Comparison of distortion, $f$ (material) \\
\hline Zircaloy-C (vendor) & $\mathrm{Ga} / \mathrm{Cd}$ & 500 & 200 & Comparison of distortion, $f$ (material) \\
\hline Zircaloy-A (vendor) & $\mathrm{Ga}$ & 500 & 200 & $\begin{array}{l}25 \mathrm{mg} \mathrm{Ga} \text {; demonstrate amount of attack } \\
\text { with decreasing } \mathrm{Ga} \text { mass }\end{array}$ \\
\hline
\end{tabular}


Table A.1. Supplemental compatibility tests of zirconium/Zircaloy with gallium or $\mathrm{Ga}_{2} \mathrm{O}_{3}$ in support of test design

\begin{tabular}{|c|c|c|c|c|}
\hline Material & $\begin{array}{c}\text { Test } \\
\text { environment } \\
\end{array}$ & $\begin{array}{l}\text { Temp. } \\
\left({ }^{\circ} \mathrm{C}\right)\end{array}$ & $\begin{array}{c}\text { Time } \\
\text { (h) }\end{array}$ & Comments \\
\hline Zircaloy-B (vendor) & $\mathrm{Ga}$ & 500 & 200 & $\begin{array}{l}25 \mathrm{mg} \mathrm{Ga} \text {; demonstrate amount of attack } \\
\text { with decreasing } \mathrm{Ga} \text { mass }\end{array}$ \\
\hline Zircaloy-C (vendor) & $\mathrm{Ga}$ & 500 & 200 & $\begin{array}{l}25 \mathrm{mg} \mathrm{Ga} \text {; demonstrate amount of attack } \\
\text { with decreasing Ga mass }\end{array}$ \\
\hline Zircaloy-A (vendor) & $\mathrm{Ga}$ & 500 & 200 & $\begin{array}{l}2.5 \mathrm{mg} \mathrm{Ga} \text {; demonstrate amount of attack } \\
\text { with decreasing Ga mass }\end{array}$ \\
\hline Zircaloy-B (vendor) & $\mathrm{Ga}$ & 500 & 200 & $\begin{array}{l}2.5 \mathrm{mg} \text { Ga; demonstrate amount of attack } \\
\text { with decreasing Ga mass }\end{array}$ \\
\hline Zircaloy-C (vendor) & $\mathrm{Ga}$ & 500 & 200 & $\begin{array}{l}2.5 \mathrm{mg} \mathrm{Ga} \text {; demonstrate amount of attack } \\
\text { with decreasing Ga mass }\end{array}$ \\
\hline Zircaloy-A (vendor) & $\mathrm{Ga}$ & 500 & 200 & $\begin{array}{l}0.25 \mathrm{mg} \mathrm{Ga} \text {; demonstrate amount of attack } \\
\text { with decreasing Ga mass }\end{array}$ \\
\hline Zircaloy-B (vendor) & $\mathrm{Ga}$ & 500 & 200 & $\begin{array}{l}0.25 \mathrm{mg} \mathrm{Ga} \text {; demonstrate amount of attack } \\
\text { with decreasing Ga mass }\end{array}$ \\
\hline Zircaloy-C (vendor) & $\mathrm{Ga}$ & 500 & 200 & $\begin{array}{l}0.25 \mathrm{mg} \mathrm{Ga} \text {; demonstrate amount of attack } \\
\text { with decreasing Ga mass }\end{array}$ \\
\hline
\end{tabular}

Table A.2. Status of corrosion tests of Zircaloy with gallium metal

\begin{tabular}{|c|c|c|c|c|c|c|}
\hline \multirow[b]{2}{*}{ Material } & \multirow{2}{*}{$\begin{array}{c}\text { Time } \\
\text { (h) }\end{array}$} & \multicolumn{4}{|c|}{ - Temperature $\left({ }^{\circ} \mathrm{C}\right)$} & \multirow[b]{2}{*}{ Comment } \\
\hline & & 30 & 100 & 500 & $500^{a}$ & \\
\hline \multirow{2}{*}{$\begin{array}{l}\text { Zircaloy-A } \\
\text { (vendor) }\end{array}$} & 200 & & & $\checkmark^{b}$ & $\checkmark$ & No attack at 30 or $100^{\circ} \mathrm{C}$; Intermetallic \\
\hline & 700 & $\checkmark$ & $\checkmark$ & $\checkmark$ & $\checkmark$ & compound formation $(\mathrm{ICF})$ at $500^{\circ} \mathrm{C}$ \\
\hline \multirow[b]{2}{*}{$\begin{array}{l}\text { Zircaloy-B } \\
\text { (vendor) }\end{array}$} & 200 & & & $\checkmark$ & $\checkmark$ & ICF; dimensional distortion \\
\hline & 700 & $\checkmark$ & $\checkmark$ & $\checkmark$ & $\checkmark$ & $\begin{array}{l}\text { No attack at } 30 \text { or } 100^{\circ} \mathrm{C} \text {; ICF at } 500^{\circ} \mathrm{C} \\
\text { but no increase over } 200 \mathrm{~h} \text {; dimensional } \\
\text { distortion }\end{array}$ \\
\hline & 200 & & & $\checkmark$ & $\checkmark$ & ICF; dimensional distortion \\
\hline $\begin{array}{l}\text { Zircaloy-C } \\
\text { (vendor) }\end{array}$ & 700 & $\checkmark$ & $\checkmark$ & $\checkmark$ & $\checkmark$ & $\begin{array}{l}\text { No attack at } 30 \text { or } 100^{\circ} \mathrm{C} \text {; ICF at } 500^{\circ} \mathrm{C} \\
\text { but no increase over } 200 \mathrm{~h} \text {; dimensional } \\
\text { distortion at } 500^{\circ} \mathrm{C}\end{array}$ \\
\hline
\end{tabular}

${ }^{a}$ With cadmium.

${ }^{b} \checkmark$-Completed test. 
Table A.3. Status of corrosion tests of Zircaloy with $\mathrm{Ga}_{2} \mathrm{O}_{3}$

\begin{tabular}{|c|c|c|c|c|c|c|}
\hline \multirow[b]{2}{*}{ Materials } & \multirow{2}{*}{$\begin{array}{l}\mathrm{Ga}_{2} \mathrm{O}_{3}(\mathrm{wt} \\
\%)\end{array}$} & \multirow{2}{*}{$\begin{array}{c}\text { Time } \\
\text { (weeks) }\end{array}$} & \multicolumn{3}{|c|}{ Temperature $\left({ }^{\circ} \mathrm{C}\right)$} & \multirow[b]{2}{*}{ Comment } \\
\hline & & & 300 & 500 & 700 & \\
\hline \multirow{5}{*}{$\begin{array}{l}\text { Zircaloy-A } \\
\text { (vendor) }\end{array}$} & 100 & 6 & $v^{a}$ & $\checkmark$ & $\checkmark$ & \\
\hline & 100 & 12 & $\checkmark$ & $\checkmark$ & $\checkmark$ & \\
\hline & 1.0 & 6 & $\checkmark$ & $\checkmark$ & $\checkmark$ & \\
\hline & 0.2 & 6 & $\checkmark$ & $\checkmark$ & $\checkmark$ & \\
\hline & 0.1 & 6 & $\checkmark$ & $\checkmark$ & $\checkmark$ & \\
\hline \multirow{5}{*}{$\begin{array}{l}\text { Zircaloy-B } \\
\text { (vendor) }\end{array}$} & 100 & 6 & $\checkmark$ & $\checkmark$ & $\checkmark$ & $\begin{array}{l}\text { No interaction at } 300^{\circ} \mathrm{C} ; \mathrm{ZrO}_{2} \text { at } 500 \\
\text { and } 700^{\circ} \mathrm{C} \text {; intermetallic compound } \\
\text { formation (ICF) at } 700^{\circ} \mathrm{C}\end{array}$ \\
\hline & 100 & 12 & $\checkmark$ & $\checkmark$ & $\checkmark$ & $\begin{array}{l}\text { Same as for } 6 \text { weeks except greater } \\
\text { depth of interaction at } 700^{\circ} \mathrm{C}\end{array}$ \\
\hline & 1.0 & 6 & $\checkmark$ & $\checkmark$ & $\checkmark$ & \\
\hline & 0.2 & 6 & $\checkmark$ & $\checkmark$ & $\checkmark$ & \\
\hline & 0.1 & 6 & $\checkmark$ & $\checkmark$ & $\checkmark$ & \\
\hline \multirow{5}{*}{$\begin{array}{l}\text { Zircaloy-C } \\
\text { (vendor) }\end{array}$} & 100 & 6 & $\checkmark$ & $\checkmark$ & $\checkmark$ & $\begin{array}{l}\text { No interaction at } 300^{\circ} \mathrm{C} ; \mathrm{ZrO}_{2} \text { at } 500 \\
\text { and } 700^{\circ} \mathrm{C} \text {; ICF at } 700^{\circ} \mathrm{C}\end{array}$ \\
\hline & 100 & 12 & $\checkmark$ & $\checkmark$ & $\checkmark$ & $\begin{array}{l}\text { Same as for } 6 \text { weeks except greater } \\
\text { depth of interaction at } 700^{\circ} \mathrm{C}\end{array}$ \\
\hline & 1.0 & 6 & $\checkmark$ & $\checkmark$ & $\checkmark$ & \\
\hline & 0.2 & 6 & $\checkmark$ & $\checkmark$ & $\checkmark$ & \\
\hline & 0.1 & 6 & $\checkmark$ & $\checkmark$ & $\checkmark$ & \\
\hline
\end{tabular}

${ }^{a} \checkmark$ - Completed.

Table A.4. Status of mechanical tests of Zircaloy with gallium metal

\begin{tabular}{|c|c|c|c|c|c|c|}
\hline \multirow[b]{2}{*}{ Material } & \multirow[b]{2}{*}{ Type } & \multicolumn{4}{|c|}{ Temperature $\left({ }^{\circ} \mathrm{C}\right)$} & \multirow[b]{2}{*}{ Comment } \\
\hline & & 30 & 100 & 300 & $300^{a}$ & \\
\hline \multirow{2}{*}{$\begin{array}{l}\text { Zircaloy-A } \\
\text { (vendor) }\end{array}$} & $\operatorname{LME}^{b}$ & $\sim^{c}$ & $\checkmark$ & & & \\
\hline & $\mathrm{CM}^{d}$ & & & $\checkmark$ & ${ }_{i} x^{e}$ & \\
\hline \multirow{2}{*}{$\begin{array}{l}\text { Zircaloy-B } \\
\text { (vendor) }\end{array}$} & LME & $\checkmark$ & $\checkmark$ & & & \\
\hline & $\mathrm{CM}$ & & & $\checkmark$ & $\mathrm{x}$ & \\
\hline \multirow{2}{*}{$\begin{array}{l}\text { Zircaloy-C } \\
\text { (vendor) }\end{array}$} & LME & $\checkmark$ & $\checkmark$ & & & \\
\hline & $\mathrm{CM}$ & & & $\checkmark$ & $\mathrm{x}$ & $\begin{array}{l}\text { Fracture surface exhibited nonductile } \\
\text { features }\end{array}$ \\
\hline
\end{tabular}

${ }^{a}$ With cadmium.

${ }^{b}$ LME - Constant extension rate tensile (CERT) test at temperature (triplicate tests).

c $\checkmark$-Completed test.

${ }^{d} \mathrm{CM}-\mathrm{CERT}$ test at room temperature after $200 \mathrm{~h}$ at temperature (triplicate tests).

${ }^{e} \mathrm{x}$ - Cancelled. 
Table A.5. Status of room-temperature, corrosion-mechanical ${ }^{a}$ tests of Zircaloy with $\mathrm{Ga}_{2} \mathrm{O}_{3}$

\begin{tabular}{|c|c|c|c|c|c|}
\hline \multirow[b]{2}{*}{ Materials } & \multirow{2}{*}{$\begin{array}{c}\mathrm{Ga}_{2} \mathrm{O}_{3} \\
(w t \%)\end{array}$} & \multicolumn{3}{|c|}{ Temperature $\left({ }^{\circ} \mathrm{C}\right)$} & \multirow[b]{2}{*}{ Comment } \\
\hline & & 300 & 500 & 700 & \\
\hline \multirow{6}{*}{$\begin{array}{l}\text { Zircaloy-A } \\
\text { (vendor) }\end{array}$} & 100 & $\boldsymbol{V}^{b}$ & $\checkmark$ & $\mathrm{x}^{c}$ & \\
\hline & 1.0 & $\checkmark$ & $\checkmark$ & $\mathbf{x}$ & \\
\hline & 0.2 & $\checkmark$ & $\checkmark$ & $\mathrm{x}$ & \\
\hline & 0.1 & $\checkmark$ & $\checkmark$ & $\mathrm{x}$ & \\
\hline & 0 & $\checkmark$ & $\checkmark$ & $\mathrm{x}$ & \\
\hline & empty & $\checkmark$ & $\checkmark$ & $\mathrm{x}$ & \\
\hline \multirow{6}{*}{$\begin{array}{l}\text { Zircaloy-B } \\
\text { (vendor) }\end{array}$} & 100 & $\checkmark$ & $\checkmark$ & $\bar{x}$ & \\
\hline & 1.0 & $\checkmark$ & $\checkmark$ & $\mathrm{x}$ & \\
\hline & 0.2 & $\checkmark$ & $\checkmark$ & $x$ & \\
\hline & 0.1 & $\checkmark$ & $\checkmark$ & $x$ & \\
\hline & 0 & $\checkmark$ & $\checkmark$ & $\mathrm{x}$ & \\
\hline & empty & $\checkmark$ & $\checkmark$ & $\mathrm{x}$ & \\
\hline \multirow{6}{*}{$\begin{array}{l}\text { Zircaloy-C } \\
\text { (vendor) }\end{array}$} & 100 & $\checkmark$ & $\checkmark$ & $\mathrm{x}$ & \\
\hline & 1.0 & $\checkmark$ & $\checkmark$ & $\mathrm{x}$ & \\
\hline & 0.2 & $\checkmark$ & $\checkmark$ & $x$ & \\
\hline & 0.1 & $\checkmark$ & $\checkmark$ & $\mathrm{x}$ & \\
\hline & 0 & $\checkmark$ & $\checkmark$ & $\mathrm{x}$ & \\
\hline & empty & $\checkmark$ & $\checkmark$ & $\mathrm{x}$ & \\
\hline
\end{tabular}

${ }^{a}$ Constant extension rate tensile test at room temperature after 6 weeks at temperature (triplicate tests).

${ }^{b} \checkmark$-Completed.

$c_{\mathrm{x}}$ - Cancelled.

Table A.6. Status of high-temperature tensile, corrosion-mechanical ${ }^{a}$ tests of Zircaloy with $\mathrm{Ga}_{2} \mathrm{O}_{3}$

\begin{tabular}{|c|c|c|c|c|}
\hline \multirow[b]{2}{*}{ Materials } & \multirow{2}{*}{$\begin{array}{c}\mathrm{Ga}_{2} \mathrm{O}_{3} \\
(\mathrm{wt} \%)\end{array}$} & \multicolumn{2}{|c|}{ Temperature $\left({ }^{\circ} \mathrm{C}\right)$} & \multirow[b]{2}{*}{ Comment } \\
\hline & & 300 & 500 & \\
\hline \multirow{6}{*}{$\begin{array}{l}\text { Zircaloy-A } \\
\text { (vendor) }\end{array}$} & 100 & $\boldsymbol{V}^{b}$ & $\checkmark$ & \\
\hline & 1.0 & $\mathrm{x}^{c}$ & $\mathrm{x}$ & \\
\hline & 0.2 & $\mathrm{x}$ & $\mathrm{x}$ & \\
\hline & 0.1 & $\checkmark$ & $\checkmark$ & \\
\hline & 0 & $\mathrm{x}$ & $\mathrm{x}$ & \\
\hline & empty & $\nu$ & $\checkmark$ & \\
\hline \multirow{6}{*}{$\begin{array}{l}\text { Zircaloy-B } \\
\text { (vendor) }\end{array}$} & 100 & $\mathrm{x}$ & $\mathrm{x}$ & \\
\hline & 1.0 & $x$ & $\mathrm{x}$ & \\
\hline & 0.2 & $x$ & $\mathrm{x}$ & \\
\hline & 0.1 & $\mathrm{x}$ & $\mathrm{x}$ & \\
\hline & 0 & $\mathrm{x}$ & $\mathrm{x}$ & \\
\hline & empty & $x$ & $x$ & \\
\hline \multirow{6}{*}{$\begin{array}{l}\text { Zircaloy-C } \\
\text { (vendor) }\end{array}$} & 100 & $\checkmark$ & $\checkmark$ & \\
\hline & 1.0 & $\mathrm{x}$ & $\mathrm{x}$ & \\
\hline & 0.2 & $\mathrm{x}$ & $\mathrm{x}$ & \\
\hline & 0.1 & $\checkmark$ & $\checkmark$ & \\
\hline & 0 & $\mathrm{x}$ & $\mathrm{x}$ & \\
\hline & empty & $\checkmark$ & $\checkmark$ & \\
\hline
\end{tabular}

${ }^{a}$ Constant extension rate tensile test at temperature after 6 weeks at temperature (triplicate tests).

${ }^{b} \checkmark$ - Completed duplicate tests.

${ }^{c} \mathrm{x}$ - Cancelled. 